\title{
Rethinking Intangible Injuries: A Focus on Remedy
}

\author{
Stanley Ingber $\dagger$
}

Theoretically the tort process serves to compensate victims, disperse and thus minimize the impact of the losses they experience, deter wrongdoers, and vindicate important societal and personal values. ${ }^{1}$ Moreover, these goals are to be accomplished without unduly impairing or discouraging societal development and human interactions. In recent years, however, critics have questioned whether the tort process effectively achieves these goals. ${ }^{2}$

This questionmg is most justified when directed at the tort system's method of assessing and compensating intangible injuries which, ostensibly, are both nontransferable and nonquantifiable. For example, money damages alone will not repair one's reputation, restore one's privacy, or end one's emotional distress. Consequently, rather than dispersing and minimizing the loss, money damages may compound the aggregate societal injury by mcreasing the cost of certain activities without correspondingly reducing the impact of the plaintiff's personal injury. Furthermore, the nonquantifiable nature of intangible injuries impedes the tort process' traditional mechamisms for controlling juries and avoiding excessive deterrence of beneficial, though risky, activities. For example, activities that potentially impair reputation or violate privacy are highly affected by the risk of excessive damage awards. Such activities, though potentially harmful, are normally protected by free speech and press guarantees. Consequently, allowing the tort process to compensate for intangible mjuries at times may jeopardize rather than vindicate recogmzed social values.

In spite of growing criticism of the tort process, tort law continues

$\dagger$ Professor of Law, University of Florida. B.A. 1969, Brooklyn College; J.D. 1972, Yale University.

1. See O.W. Holmes, The Common Law 5, 115-16 (Howe ed. 1963); P. KeEton \& R. Keeton, Cases and Materials on the LaW of Torts 1-2 (2d ed. 1977); W. Prosser, HaNdBOOK OF THE LAW OF TORTS §§ 1-4 (4th ed. 1971); Calabresi, The Decision for Accidents: An Approach to Nonfault Allocation of Costs, 78 HARv. L. Rev. 713, 713 (1965).

2. See, eg., J. O'ConNell, THe LaWsuit LotTery: ONLY THe LAWYers WIN (1979); Franklin, Replacing the Negligence Lottery: Compensation and Selective Reimbursement, $53 \mathrm{~V}_{\mathrm{A}} \mathrm{L}$. REv. 774 (1967); Pierce, Encouraging Safety: The Limits of Tort Law and Government Regulation, 33 VAND. L. REv. 1281 (1980). Many of the articles in this symposium further demonstrate the growing dissatisfaction with the tort process. 
to expand its coverage. ${ }^{3}$ In the last twenty-five years there has been a significant movement toward recognizing "intangible" interests by more fully protecting against the infliction of "emotional distress." scholar explains this broadenimg of liability for psychic injuries as a parallel to the growth of a "me-generation"s striving for self-awareness, personal well-being, health, and psychic security. ${ }^{6}$ This cultural focus on the need for "inner peace" and the value of psychological therapy" suggests that society perceives intangible injuries as real and that fairness demands that the tort system should provide some method of redress to victims of such injuries. This Article will analyze this perception and determine whether it can be satisfied while avoiding the pitfalls of the present tort process.

Tort scholarship typically focuses on the issue of liability-which party should prevail in a suit for damages. Accordingly, scholarship concerning intangible injuries often embraces an "all or nothing" attitude, with liability resulting either in "full" compensation or no compensation at all. ${ }^{8}$ This Article will take a different approach, concentrating on

3. Smolla, Let the Author Beware: The Rejuvenation of the American Law of Libel, 132 U. PA. L. REv. I passim (1983). The expansive development of tort law, in fact, may not be "in spite of growing criticism" but both a cause and result of such criticism. The trend favoring strict liability was fostered by critics who felt that the tort process' focus on fault interfered with compensation and risk-spreading goals. Id. at 93. See generally Franklin, supra note 2, at 781-88. In turn, the growth of liability for medical malpractice and product liability has created great political pressure, primarily from medical and industrial sources, for review of the tort litigation process. FlORIDA BAR, REPORT OF THE TORT LITIGATION REVIEW COMMISSION 1 (1984).

4. See, e.g., Dillon v. Legg, 68 Cal. 2d 728, 441 P.2d 912, 69 Cal. Rptr. 72 (1968); Battalla v. State, 10 N.Y.2d 237, 176 N.E.2d 729, 219 N.Y.S.2d 34 (1961). Damage claims for mental distress are now even allowed in some breach of contract actions. See Bjorkman, $B \& M$ Homes, Inc. $v$. Hogan: A Breakthrough in the Law's Reluctance to Award Damages in Contract for Mental Anguish or Other Non-Economic Detriments, 26 S.D.L. REV. 48 (1981). Broadly defined, emotional distress may include such diverse phenomena as fright and its physical consequences, humiliation, embarassment, and empathy.

5. Smolla, supra note 3, at 11. Professor Smolla gives credit to journalist Tom Wolfe for introducing the term "me-generation" into the lexicon. Id. at $20 \mathrm{n}$. 106 (citing Wolfe, The "Me" Decade and the Third Great Awakening, NEw YoRK, Aug. 23, 1976 at 26, 34).

6. Lasch, The New Narcissist Society, N.Y. REV. Books, Sept. 30, 1976, at 5 ("[P]ersonal satisfaction . . . is one of the main themes of the Seventies"); see also E. SCHUR, THE AWARENESS Trap: Self Absorption INSTEAd of Social Change 1-8 (1976) (noting increasing American interest in becoming aware of oneself and one's feelings).

7. As the public more widely understands mental illness and psychological therapy, individuals are more willing to make claims of emotional distress and society is more willing to recognize such claims. Galante, When the Mind is Hurt, Nat'1 L.J., May 28, 1984, at 28 col. 3.

8. Compare Bell, The Bell Tolls: Toward Full Tort Recovery for Psychic Injury, 36 U. FLA. L. REV. 333 (1984) (advocating total liability for emotional distress suffered by witnesses of accidents) with Pearson, Liability to Bystanders for Negligently Inflicted Emotional Harm-A Comment on the Nature of Arbitrary Rules, 34 U. FLA. L. REV. 477 (1982) (supporting severe limitations on liability for bystander's emotional harm). See New York Times Co. v. Sullivan, 376 U.S. 254 (1964) (confronting free speech issues in defamation by significantly restricting liability). But see Gertz v. Robert Welch, Inc., 418 U.S. 323 (1974) (a modest attempt to rethink defamation law in terms of damages). 
questions of damages and remedies, rather than liability. ${ }^{9}$

Such an approach must begin by examining the tort process itself. Part I will analyze the traditionally stated goals of tort law and evaluate the extent to which various remedies for intangible injuries further these goals. While the term "intangible injuries" most often is used to refer to nonphysical injuries ${ }^{10}$, recovery for such injuries is often justified by coinparing the difficulties it presents for the tort process with those similar difficulties often "sucessfully" confronted when individuals are compensated for pain and suffering. ${ }^{11}$ Pain and suffering is essentially the prototype of a nontransferable, nonquantifiable injury. Consequently, to avoid any appearance of inconsistency, Part I considers pain and suffering in conjunction with emotional distress while analyzing intangible injuries generally. It concludes by proposing a model of damages that achieves the legitimate goals of tort law more effectively than the present system.

The damage model developed in Part I, however, does not adequately confront the value conflicts associated with granting liability for reputational and privacy injuries. Although these injuries are also intangible, they result from processes of communication and, therefore, differ greatly from those intangible injures that result from accidents generally. Remedies for injuries generated from communicative activities must account for the conflicting social interests of individual decency and free expression. Part II considers the torts of defamation and privacy invasion and explores this inherent value clash. It then refines the proposed damage model so as to minimize this conflict and fulfill more completely the values of the tort system.

9. The need to focus on damages and the difficulty academics find in fulfilling that need was recognized by Professor Louis Jaffe more than twenty years ago:

I suggest that the crucial controversy in personal injury torts today is not in the area of liability but of damages. Questions of liability have great doctrinal fascination. Questions of damage-and particularly their magnitude-do not lend themselves so easily to discourse. Professors dismiss them airily as matters of trial administration. Judges consign them uneasily to juries with a minimum of guidance, occasionally observing loosely that there are no rules for assessing damages in personal injury cases. There is analogy for this situation in Jerome Frank's complaint that fact finding, though of paramount importance, is neglected by teachers who devote themselves too exclusively to appellate law. This may reflect not so much their judgment of relative importance (as Judge Frank supposes) as the relative adaptability of the subjects to conceptualization. And so it probably is with the subject of damages.

Jaffe, Damages for Personal Injury: The Impact of Insurance, 18 LAW \& CONTEMP. ProBs. 219, 221-22 (1953) (footnote omitted).

10. Nonphysical injuries include but are not limited to elnotional distress, defamation, and privacy invasions.

11. "[M]ental suffering is scarcely inore difficult of proof, and certainly no harder to estimate in terms of unoney than the physical pain of a broken leg, which never has been denied compensation . . ." W. Prosser, supra note 1, § 12, at 50. See Bell, supra note 8, at 354; Goodrich, Emotional Disturbances as Legal Damage, $20 \mathrm{MiCH}$. L. REV. 497 (1922). The similarities between pain and suffering and emotional distress are sufficient to foster claims of injustice whenever the legal system approaches one of these injuries differently from the other. 
I

\section{Creating a General Proposal for Intangible} INJURIES: MEETING TORT SySTEM GOALS

An effective approach to intangible injuries is best formulated by first evaluating the aims of tort law generally and then developing a model for remedying intangible injuries most conducive to accomplishing those goals.

\section{A. Compensation}

Commentators often suggest that the primary function of tort damages is to compensate victims for injuries. ${ }^{12}$ Damages, according to this view, are intended to restore the plaintiff to the position he occupied prior to the tortious act of the defendant. ${ }^{13}$ Because accident victims genuinely suffer physical pain and emotional distress, they have a strong, intuitively legitimate claim to compensation for such injuries.

Such a clain presumes, however, that the tort system is committed to total compensation. The tort system does not, however, purport to redress all material losses, physical or mental. Although an injured party may have a seemingly legitimate claim to compensation, the tort system concerns itself only with "legally cognizable" losses. Some victims go unremedied, for example, either because their injury was inflicted without fault or because they also acted carelessly. Yet they are just as hurt and disabled as those who qualify for compensation. A system intended to make injured parties whole would assure compensation for all accident victims. Moreover, social insurance would accomplish such a compensation goal much more efficiently than the present tort system. Considering the high cost presently expended to deterimine whether a victim sliould be compensated, ${ }^{14}$ it is reasonable to presume that only a purpose

12. C. McCormick, Handbook on the Law of Damages $\$ \S 20,137$ (1935); 1 T. Sedgwick, A Treatise on the Measure of Damages $\$ 29$ (9th ed. 1913); 1 J. SutherLaNd, A TREATISE ON THE LAW OF Damages $\$ \S 1,12$ (4th ed. 1916); Calabresi, supra note 1, at 713; James, Damages in Accident Cases, 41 CoRnell L.Q. 582, 582 (1956); Comment, Loss of Enjoyment of Life as a Separate Element of Damages, 12 PAC. L.J. 965, 965 (1981).

13. Comment, supra note 12 , at 965 .

14. New Zealand, recognizing this cost inefficiency, has abolished all personal injury actions and substituted a system of administrative compensation for all victims of accidents. See Marks, $A$ First in National No-Fault: The Accident Compensation Act 1972 of New Zealand, 47 AusTL. L.J. 516 (1973); Vennel, The Scope of National No-Fault Accident Compensation in Australia and New Zealand, 49 AusTL. L.J. 22 (1975).

Professor Richard Epstein has suggested a less radical method for assuring compensation to all accident victims. While retaining the civil suit for personal injuries, he has proposed a theory of strict liability based on a series of causal paradigms. He bases his proposal on " "a deep sense of common law morality that one who hurts another should compensate him." "Epstein, A Theory of Strict Liability, 2 J. LEGAL STUD. 151, 168 n.48 (1973) (quoting Green, Foreseeability in Negligence Law, 61 Colum. L. Rev. 1401, 1408 (1961)). 
superior to accident victim compensation can adequately justify the present tort system.

Similarly, tort law does not compensate for all losses that are the result of even concededly tortious behavior. For example, if $A$ destroys $B$ 's watch given to him by his late and beloved father, $B$ likely will be compensated for only the market value of his destroyed timepiece. ${ }^{15} \mathrm{But}$ due to its sentimental value $B$ would never have sold the watch at its market price. Given $A$ 's wrongful behavior, why should $B$ not be compensated for the loss of the watch's enhanced value to him, and for his emotional distress at its destruction? This obvious discrepancy in the evaluation of $B$ 's injury ${ }^{16}$ seems anomalous in a system supposedly attempting to "make the victim whole."

To the extent that tort law does not account for the sentimental value $B$ attaches to his watch, he is forced to accept that loss without compensation. $B$ may be an unusually sensitive individual, but in tort law the defendant is generally assumed to "take his victim as he finds him." 17 However, im $B$ 's case, he must take his own precautions-either by not taking the watch out in public where it may be damaged or by

15. In property damage situations, courts largely have denied recovery for mental distress caused by unintentional injury to either real or personal property. See Zeigler v. F Street Corp., 248 Md. 223, 235 A.2d 703 (1967) (no recovery for mental suffering due to flood of land); Buchanan v. Stout, 123 App. Div. 648, 108 N.Y.S. 38 (1908) (no recovery for mental distress resulting from the death of plaintiff's cat). However, when the injury to property is malicious-intentionally or fraudulently caused-mental suffering is allowed as damages. Valley Development Co. v. Weeks, 147 Colo. 591, 597, 364 P.2d 730, 733 (1961); see also Walker v. Ingram, 251 Ala. 395, 37 So. 2d 685 (1948); Murphy v. City of Tacoma, 60 Wash. 2d 603, 374 P.2d 976 (1962). Possible justification for the extended damages for willful and reckless torts is presented at infra text accompanying notes 92 , 157-58.

16. This discrepancy arises from the distinction between a "property" and "liability rule" of evaluation. Calabresi \& Melamed, Property Rules, Liability Rules, and Inalienability: One View of the Cathedral, 85 HARV. L. REv. 1089, 1092 (1972). When the owner of any property or value may set his own price before relinquishing it, his ownership is protected by a property rule. No one may merely approach him, tender him the market value of his possession, and demand transfer. No matter how unreasonable the set price may be, it must be rendered before a legally recognized sale has taken place. However, if the property or value is accidentally, although negligently destroyed, the owner may not insist that the negligent party pay any price the owner imposes. Because the tortfeasor already has requisitioned the property, compelling him to meet any price set by the owner could result in exorbitant valuations. To avoid owner windfalls, the law requires the tortfeasor to pay an objectively determined cost for the destroyed item even though this price may be less than that at which the owner would have sold it prior to the accident. In this context, ownership is protected by a liability rule of evaluation. Id. The property rule encourages personal negotiations, while the liability rule relies on market determinations.

In liability situations, when the defendant rarely has a prior opportunity to negotiate with the plaintiff about value, the plaintiff must lose the differential between the values derived by the property and liability rules to avoid windfalls to plaintiffs and extortion of defendants. These concerns are not as significant in intentional torts. Negotiations are theoretically possible. A willful tortfeasor, if allowed the advantage of a liability rule of evaluation, may decide that the market value of an injury to another is worth the price of the benefit he gains. Therefore, damages for willful torts usually are set as close as possible to those that would have been derived under a property rule.

17. E.g., Tabor v. Miller, 389 F.2d 645, 647 (3d Cir. 1968); Stephens v. Koch, 192 Colo. 531, 
insuring it for its enhanced value to him. ${ }^{18}$ The special feeling $B$ has for his watch, altliougli understandable and perhaps desirable, attaclies to this specific good in a highly individuatized, particular way. The owner tlierefore knows better tlian the injurer wliat is of special value and when unique precautions are justified. ${ }^{19}$ In such circuunstances "full" coinpensation is not forthcoming.

The concept of proximate cause further limits coinpensation to victims of tortious beliavior. For example, defendant $C$ negligently starts a fire which burns down $D$ 's factory. $D$ may sue for the loss of his building, yet $D$ 's einployees may not sue for the loss of their job despite the foreseeable nature of their injury. Clearly $C$ 's conduct is a but-for condition of the employees' job loss but, because their injury is 'insufficiently direct," they must turn to unemployment insurance rather tlian the tortfeasor for coinpensation. ${ }^{20}$ This argument, often used to limit liability for einotional distress to accident witnesses, must also be explored inore fully. ${ }^{21}$

The crucial point here, however, is to dispel notions that tort law provides full compensation for personal injury losses. The tort systein, at best, promises only partial compensation. ${ }^{22}$ The tort system's commitment to full compensation is clearly not alone sufficient justification to require coinpensation for all damages due to tortious behavior. The

561 P.2d 333, 334 (1977); see REstatement (SECOND) of ToRTs § 461, at 502 (1965) "[T] he law is not for the protection of the physically sound alone." W. PROSSER, supra note $1, \S 54$, at 328 .

18. First-party insurance covering a specific piece of property for a specific, sentimentally enhanced value is significantly less expensive than obtaining third-party insurance against loss of sentimentally valued property belonging to all others.

19. G. Calabresi, Ideals, Beliefs, Attirudes and the Law $72-73$ (1985). Often the defendant takes his victim as he finds him precisely because society is unwilling to require the unusually sensitive individual to take those extreme precautions necessary to protect himself adequately. The thin-skulled individual-well known to tort students-would be required either to avoid all potentially dangerous contexts, e.g., the public highways, or would always need to wear a metal helmet. We are not willing to require either. But the distinction is not between physical and property damage. A concert violinist who decides to spend his vacation working together with the "real" proletariat in the coal mines of Appalachia will hikely, following a mine accident which injures his hands, not be awarded compensation for his lost income as a musician. We are unwilling to discourage him from driving a car where, if he were injured, he could collect for all income losses. We are willing to discourage hiun from working in the mine by determining that in those circumstances he assumed the risk, not of an injury to his hands, but of the loss of the enhanced value of that injury due to his inusical talents. The precautions and insurance cost are more appropriately those of the music industry than of mining. For a discussion of cost allocation, sec infra text accompanying notes $100-12$.

20. In some jurisdictions, if the fire spreads from $D$ 's to $E$ 's property, $D$ could sue $C$ but $E$ could not. See Palsgraf v. Long Island Railroad, 248 N.Y. 339, 352, 162 N.E. 99, 103-04 (Andrews, J., dissenting) (New York fire rule allows suit only by property owner initially inpacted by fire. "Yet the wrongful act as directly harmed the one as the other").

21. See infra text accoinpanying notes 197-215.

22. First-party or social insurance must be turned to for compensation of these "nonlegally cognizable" losses. 
question remains whether victims ought to be compensated for intangible injuries.

\section{Compensation of Intangible Injury: A Preliminary Analysis}

It is difficult to justify monetary damages for intangible injuries exclusively on the basis of victim compensation. Significantly, such injuries cannot be readily quantified. Translating pain and suffering or emotional distress into monetary terms poses tremendous problems of proof $^{23}$ because, unlike the situation with property, no market exists to provide a standard for compensating a victiun of such a loss. ${ }^{24}$ Such injuries have no measurable dimensions, mathematical or financial. ${ }^{25}$

Courts have recognized that there is no exchange value for pain and suffermg or emotional distress and, therefore, have relied upon the collective judgment of juries to quantify such injuries. Yet without some basis for calculating loss, damage awards are apt iu many cases to be unfair to one or the other of the parties. But no such standards have been developed. Juries are left with nothing but their consciences to guide them. ${ }^{26}$ Consequently, wide variations in monetary awards result, ${ }^{27}$ and there

23. Pierce, supra note 2, at 1290-94; Rosenberg, The Causal Connection in Mass Exposure Cases: $A$ "Public Law" Vision of the Tort System, 97 HARv. L. REv. 851, 879 (1984).

24. Since there is no market by which to determine monetary worth, a liability rule of evaluation is unavailable. On the other hand, a property rule, if used, would allow an injured party to demand unlimited damages.

Even if a market for potential accident victims could be devised, those actually injured likely would still feel inadequately compensated. Once imjured, they probably would believe that the price they set on the basis of a perceived possibility of injury was grossly insufficient to account for the injury actually experienced.

25. As one author notes, there is "simply no way of working out any relation between the value of money-what it will buy-and damages awarded for pain and suffering, and disabilities." P.S. ATIYAH, ACcidents, COMPENSATION AND the LAw 213 (3d ed. 1980).

26. Generally, jury instructions supply no instrument for measuring pain and suffering. The following charge by a New York judge demonstrates this inadequacy: "I know of no arbitrary rule that you can apply in determining the amount to be included for scar or permanency of injury, or pain and suffering, except again, Ladies and Gentlemen, your own good sense and good judgment as men and women of affairs." Zelermyer, Damages for Pain and Suffering, 6 SYRACuSE L. REV. 27, 30 (1954) (quoting Record, Poliani v. Scibilia, 281 A.D. 1071, 122 N.Y.S.2d 54 (1953) (mem.)); see Southern Ry. v. Gresham, 114 Ga. 183, 39 S.E. 883 (1901) (jurors instructed that damages are left to the enlightened conscience and intelligence of impartial jurors); see also C. MCCoRMICK, supra note $12, \S 88$, at 318-19.

27. In fact, most damage awards for intangible injuries could be arbitrarily multiplied or divided by a factor of two and they would be as defensible as they are presently. P.S. ATIYAH, supra note 25 , at 213 . One attorney suggests that plaintiff's counsel should "just pluck a figure out of the air and hope it's high enough." Galante, supra note 7, at 28 col. 2. Consider, for example, Cook v. Ross Island Sand \& Gravel Co., 626 F.2d 746 (9th Cir. 1980), where the court affirmed an award of $\$ 35,000$ for pain and suffering for the $21 / 2$ minutes victim was alive while drowning.

Variations in monetary award, however, do not necessarily signal a flawed system. For example, depending on the nervous sensibilities of the sufferer, two persons suffering the same kind of injury may experience differing degrees of pain. Herb v. Hallowell, $304 \mathrm{~Pa} .128,133,154$ A. 582, 584 (1931). Suclı persons, tlierefore, might differ greatly in their evaluation of "reasonable compensation." The unique nature of the experience of botll mental and pliysical pain, while possibly 
remains the danger that juries may be responding to irrelevant or even illegitimate distinctions in the cases. ${ }^{28}$

Closely related to the lack of standards for jury deliberation is the belief that compensation for intangible injuries promotes claimant fraud and bill-padding. Juries are presumed to be strongly plaintiff-oriented, especially when large corporations or wealthy insurance companies are the real (if not the named) defendants. ${ }^{29}$ Because proof of intangible injuries is heavily dependent upon plaintiff testimony and because such injuries lack a market value to serve as a ceiling for damages, defendants in cases involving intangible injuries are particularly susceptible to the threat of jury bias. Consequently, to avoid tlie risk and uncertainty of a jury verdict, such defendants often settle claims for noneconomic loss by offering a fixed multiple of more easily provable economic loss, for example, medical expenses. ${ }^{30}$ A compensation system which calculates damages for intangible injuries in this manner encourages both nuisance suits and fraud. It also promotes bill-padding which, by inflating economic accident costs, can raise proportionately compensation for intangible injury. ${ }^{31}$ Considering these factors, the administration of the law under the present system for coinpensating intangible injuries is vulnerable to criticism of unfairness and abuse.

Although the nonquantifiable nature of intangible injuries creates obvious compensation problems, these problems are not unique to such injuries. For example, damages for lost future wages, often viewed as tangible, economic losses, are also uncertain and a matter of conjecture. Even though the testimony employed to determine future wage loss uses the rhetoric of dollars and cents and statistics, the trier of fact is actually being asked to predict how long a plaintiff will live, ${ }^{32}$ what jobs he would have held and what salaries he would have received if not for the injury. When one contemplates this task in the context of the wrongful death of

explaining some variation in awards, is itself often expressed as a ground for disallowing compensation. See supra text accompanying notes 15-19, and infra text accompanying notes 134-40.

28. James, supra note 12, at 583. Trial and appellate courts, of course, can overturn an award for an amount "a reasonable person would [not] estimate as fair compensation." RESTATEMENT (SECOND) OF TORTS $\S 912$ comment b (1965). See, e.g., Gary v. Schwartz, 43 A.D.2d 562, 349 N.Y.S.2d 322 (1973). But the judge also lacks an instrnment for determining fair compensation.

29. W. Keeton, D. Dobbs, R. Keeton \& D. OWen, Prosser and Keeton on the LaW OF TORTS $\S 82$, at 591-92 (Sth ed. 1984) [hereinafter cited as PROSSER \& KEETON].

30. Payment for pain and suffering, for example, averages nearly one and one-half times the amount paid for economic loss. INSURANCE DEP'T OF THE STATE of NeW YORK, AUTOMOBlLE INSURANCE . . . FOR WHOSE BENEFIT? 26 (1970).

31. The problems of "post-accident inflation" of loss are graphically portrayed in a series of investigative reports in the Chicago Sun-Times quoted at length in O'Connell, $A$ Proposal to Abolish Defendants' Payment for Pain and Suffering in Return for Payment of Claimants' Attorneys' Fees, 1981 U. ILL. L. REV. 333, 334-35 (1981).

32. In a wrongful death case the jury needs to predict how long the deceased would have lived had there been no accident. 
a child, its crystal-ball gazing nature is obvious. ${ }^{33}$ Damages for intangible injuries, although admittedly difficult to quantify, appear no less justifiable on that basis alone than damages for loss of future wages.

The distinction between lost future wages and intangible injuries is the apparent transferability (or lack thereof) of the respective injuries. A typical tort involves claims for medical expenses, lost wages (past and future), and pain and suffering. Compensating the plaintiff for the first two coinpletely shifts those expenses from him to the defendant. ${ }^{34}$ The costs of medical expenses and lost wages, therefore, are transferable. Although the extent of pecuniary injuries such as future medical expenses and lost future wages inay be uncertain, the existence of such economic loss is virtually assured. To refuse any compensation because of the danger of error in determining an amount is to guarantee that all such costs are absorbed by the plamtiff rather than the defendant. An error in damage calculation, however, may be preferable to an error in damage allocation ainong the parties. ${ }^{35}$

In contrast, pain and suffering seeiningly gives rise to damages of a different, noneconomic nature. ${ }^{36}$ While a defendant who is liable for such costs suffers monetary loss, the plaintiff continues to experience pain and suffering. ${ }^{37}$ These damages, consequently, are nontransferable. ${ }^{38}$ Granting liability for nontransferable costs does not reallocate damages; rather it burdens both parties with the injury's cost. Where once there was a single injury, now two exist-the victim's continued pain and suffering and the injuror's economic dislocation.

Victim compensation, therefore, upon preliminary analysis, does not

33. Bell, supra note 8, at 355. See also Finkelstein, Pickrel \& Glasser, The Death of Children: A Nonparametric Statistical Analysis of Compensation for Anguish, 74 Colum. L. REV. 884, 884 (1974) (ridiculing states engaged in the "fanciful enterprise" of estimating the present value of the child's future wages).

34. Thus, as is discussed more fully later, the incentive to avoid such economic loss and to mitigate the impact of such damages is entirely with the tortfeasor. See infra text accompanying notes 101-07.

35. For a complete discussion of the role of cost allocation in tort, see infra text accompanying notes 100-12.

36. See generally James, supra note 12, at 603-05; Morris, Liability for Pain and Suffering, 59 COLUM. L. REv. 476 (1959); Zelermyer, supra note 26, passim

37. Since pain and suffering involves no financial loss, compensation in money cannot rest on the principle of making the plaintiff whole. Jaffe, supra note 9, at 224. "Pain is a harm, an 'injury,' but neither past pain nor its compensation has any consistent economic significance." Id.

38. This argument holds true only if the plaintiff's injury is pain and suffering or emotional distress in a pure sense rather than the prospect of uncompensated pain and suffering. Prior to the aceident, the plaintiff presumably would not have been willing to sell his endurance of the pain and distress experienced for a price equivalent to the monetary damages received. G. CALABRESI, THE COSTS of ACCIDENTS 217-18 (1970). Additionally, monetary compensation does not remove from the plaintiff the burden of physical or emotional pain. However, to the extent that the injury can be considered as uncompensated pain and distress, the damages would be transferable through compensation. 
provide a potent argument for granting tort damages for intangible injuries. $^{39}$ But this analysis, which traces arguments often presented by others, ${ }^{40}$ may be too simplistic. In many ways the injuries of pain and suffering and emotional distress are both transferable and calculable.

\section{Compensation for Intangible Injuries: An In-Depth Analysis}

If the plaintiff's injury is not merely physical and emotional distress but the fact that his distress remains unrecognized and uncompensated, the cost of such an injury is in fact transferable. ${ }^{41}$ To the extent that pain and suffering and emotional distress are real injuries, denial of compensation creates the appearance of legal and societal indifference to the victim's plight. An individual whose bodily or einotional integrity has been violated may feel a sense of continuing outrage. Because money is highly valued in our society, we use it to measure and recognize the worth of both tangible and intangible items. If society is to signify its commitment to the support of psychic well-being, ${ }^{42}$ damages for intangible injuries must be permitted. ${ }^{43}$ Compensation inay restore the plaintiff's sense of self-value, and ease his sense of outrage.

From the victim's perspective, compensation is not just reimbursement, it is making ainends for the injury done by bestowing a "consolation, a solatium." 44 Refusal to grant damages effectively bestows upon the injurer a form of legal "entitlement" to cause the injury. ${ }^{45}$ Although money damages may not be an equivalent to the injury experienced, they

39. In many ways the loss of arms and legs is also nontransferable. The argument here does not suggest that such injuries should not lead to damages but only that victim compensation may not be the only justification for such awards. Other reasons for damage awards may exist. See infra text accompanying notes $69-84,129-31,169,172-74$.

40. See sources cited supra note 36 .

41. See supra note 38 .

42. See supra text accompanying notes $5-7$.

43. Jaffe, supra note 9, at 224 .

44. Id. For a discussion of the significance of restitutive justice in tort, see infra text accompanying notes $69-99$.

45. The concept of "entitlement" is described as follows:

When a loss is left where it falls . . . it is not because God so ordained it. Rather it is because the state has granted the injurer an entitlement to be free of liability and will intervene to prevent the victim's friends, if they are stronger, from taking compensation from the injurer. The loss is shifted in other cases because the state has granted an entitlement to compensation and will intervene to prevent the stronger injurer from rebuffing the victim's requests for compensation.

Calabresi and Melamed, supra note 16, at 1091.

Professor John Rawls suggests a method of evaluating and justifying legal entitlements. $\mathrm{He}$ would consider what agreements about entitlements would likely result from a meeting of all persons about to form a society, held at a time when everyone was unaware of the position or wealth he would have in that society. J. RAwLS, A Theory OF Justice 11-12 (1971); see Michelman, Foreword: On Protecting the Poor Through the Fourteenth Amendment, 83 HARV. L. REV. 7, 15-16 (1969). Within our culture, it would be incredible if such a group gave individuals the right to cause significant physical or emotional distress. An entitlement to be free of such distress is more conceivable. 
can serve as an important symbolic means of preserving the entitlement of personal security and autonomy against infringement. ${ }^{46}$

In addition to compensation as a method of restoring a sense of personal value, pain and suffering and emotional distress may result in costs that are as quantifiable and transferable as those that exist in any other injury. Suffering can disable, leading to lost income, the need for medical attention, therapy, or drugs. ${ }^{47}$ The tort system clearly should allow recovery for these pecuniary consequences of physical and emotional distress.

Allowing damages but restricting them to these pecuniary ramifications has a number of advantages. First, it leaves momentary shock and discomfort to be borne by the victim as part of everyday life. This prevents these "mevitable aspects of the human condition"48 from generating repeated and costly hitigation issues which can lead to significantly increased imsurance costs. However, longer-lasting disabilities which are likely to cause pecuniary costs must be recognized if society is to uphold an individual's integrity and help him to cope adequately with a traumatic event. ${ }^{49}$ Furthernore, especially when dealing with those affected by emotional distress, such dainages may encourage sufferers to seek professional assistance and rehabilitation. ${ }^{50}$ Without such encouragement, these individuals might not pursue therapy due to feelings of shame or fear of stigina from acknowledging "emotional instability." The prospect of damages may suggest to such individuals that society legally recog-

46. Rosenberg, supra note 23 , at 877-79.

47. Morris, supra note 36 , at $476-77$. "A brain surgeon writhing in agony cannot operate. A tap dancer whose every movement causes pain must look for other work. An airline pilot who dulls a migraine headache with reaction-slowing drugs cannot be trusted with passengers' lives." Id.

48. Teff, Liability for Negligently Inflicted Nervous Shock, 99 LAW Q. REV. 100, 105 (1983).

49. The Hawaii Supreme Court has distimguished between two types of mental reaction to traumatic stimulus, labeling them "primary" and "secondary."

The primary response, an immediate, automatic and instinctive response designed to protect an individual froin harm, unpleasantness and stress aroused by witnessing the painful death of a loved one, is exemplified by emotional responses such as fear, anger, grief, and shock. This initial response, which is short in duration and subjective in nature, will vary in seriousness according to the individual and the particular traunatic stimulus.

Secondary responses, which may be termed traumatic neuroses, are longer-lasting reactions caused by an individual's continued inability to cope adequately with a traunatic event.

Leong v. Takasaki, 55 Hawaï 398, 411-12, 520 P.2d 758, 766-67 (1974). Secondary responses are precisely those most destructive of personal autonomy and most hikely to cause pecuniary ramifications.

50. The granting of damages might encourage both insurance companies and the medical profession to provide early crisis intervention assistance and to focus greater attention on the development of psychic rehabilitation, through counseling, pain climics and the like. The limiting of damage awards for intangible injuries to their pecuniary ramifications should be accompanied by a greater recoguition by courts of alternative and innovative methods for treating pain and emotional distress (e.g., chiropractic mampulation, acupuncture and meditation). 
nizes and encourages their seeking help for such afflictions. ${ }^{51}$

Limiting damages to pecuniary costs, while giving symbolic support and recognition to the plight of the injured party, also lessens the danger of claimant fraud or bill-padding. Since a plaintiff will receive damages only for the actual expenses incurred, he has little incentive to commit fraud or to inflate his bills since he will receive no financial benefit from such behavior.

This advantage is clearly gained for costs already incurred. It is less certain when dealing with projected costs for items such as continued therapy. Normally, damages for future projected costs are awarded as part of a lump-sum judgment. However, such awards lack any guarantees concerning the money's future use. Thus, while ostensibly granted to compensate for future medical expenses, these damages might instead be used to renovate one's home. Under such circumstances the incentive to fabricate or overstate one's suffering would remain. The use of conservatorships or trusts combined with special verdicts could assure that damages awarded were used for their designated purposes. ${ }^{52}$ The development of such an award system would both discourage fraud and encourage rehabilitation of the injured parties.

Notwithstanding all these advantages, a remedy system designed to avoid fraud by also limiting the compensation available to honest claimants is justifiably subject to criticism. Restricting damages for intangible injuries to their tangible ramifications clearly leaves part, if not a sigmificant part, of the injury to be borne by the honest plaintiff alone. Yet it seems only fair that a tortfeasor should assume all of the victim's damages.

However, awards for general, non-pecuniary damages cannot provide meaningful compensation for the victim. Society has sufficiently acknowledged the victim's right to bodily and emotional security by granting damages for the economic ramifications of his injury-his cost of coping and of being rehabilitated. The remaining injury is arguably

51. With such symbolic support individuals may seek help who never otherwise would, even though their first-party health insurance would cover any resulting expenses.

52. This assurance is never required when property for which there is an ongoing market is damaged. For example, a plaintiff whose car has been damaged may legitimately use an award computed to finance repair costs for any purpose he wishes while continuing to drive his damaged car. The plaintiff is free to use the award for purposes other than fixing the car because, prior to the accident, he could have sold his car and used the proceeds as he saw fit. The sum of the repair damages and the residual value of the car are presumed to equal the preaccident value of the automobile. The decision to use the damage award for other purposes is the equivalent of selling a portion of the car's value and using those proceeds. The plaintiff thus remains in the same financial position whether or not he repairs his car. But when dealing with intangibles for which there is no ongoing market, there is no similar guarantce that the plaintiff is compensated only to the extent necessary to return him to his preaccident condition. Consequently, it is necessary to insist that the damages be used specifically for that purpose. 
only that which is truly nonquantifiable and nontransferable and, therefore, best borne by the victim. ${ }^{53}$ When this factor is combined with the umique and individualized sensitivity of individuals to physical and emotional pain, ${ }^{54}$ meaningful compensation for nonpecuniary losses simply may be impossible. Such damages would neither restore nor rehabilitate. Rather than compensating, they merely would assure a wealthier existence than would have been experienced had there been no accident. There is, therefore, an incongruence between injury and reinedy. ${ }^{55}$

Professor Richard Pearson, however, in a recent article, ${ }^{56}$ provides an alternative perspective from which to view damages for pain and suffering. According to Pearson, damages are a method of correcting an improperly distorted pain-to-pleasure ratio. Assuming that pain could be objectively measured, a plaintiff permanently suffering ten units of pain can use money damages to purchase an offsetting ten units of pleasure, for example, an annual trip to Bermuda. The pain itself may be irreducible, "but it will be easier to bear in Bermuda."s7

Damages, according to this view, may help one become more satisfied with hife; they are a solace for suffering. Although this perspective is valuable when considering physical pain, it appears inappropriate when the injury is emotional distress due, for example, to witnessing the death of a loved one. ${ }^{58}$ Translating such injuries into dollars and cents, into pleasure/pam ratios, only demeans and trivializes the interests at stake. ${ }^{59}$ Beyond the intuitive discomfort of such calculations, it is unclear that damage awards actually are determined on the basis of such ratios. Cer-

53. If damages beyond pecumary loss are perceived necessary to symbolically demonstrate societal concern for an injured party, see supra text aceompanying notes $44-46$, a schedule of damages for severe injuries such as loss of limb may be developed. Sucl a schedule at least would reducc the risk of varied and unprincipled damage detennmations. See infra text accompanying notes 150 . 52 and note 150 .

54. As argued earlier, two people may experience the same physical injury or emotional trauma and suffer dramatically different levels of distress depending on their nervous sensibilities and ego strength. See supra note 27. See Herb v. Hallowell, $304 \mathrm{~Pa} .128,133,154$ A. 582, 584 (1931); Brody, Negligently Inficted Psychic Injuries: A Return to Reason, 7 VILL. L. REV. 232, 255-56 (1961-62).

55. The California Supreme Court, in dealing with another intangible injury, recognized this incongruence:

Loss of consortium is an intangible, nonpecuniary loss; monetary compensation will not enable plaintiffs to regain the companionship and guidance of a mother; it will simply establish a fund so that upon reaching adulthood, when plaintiffs will be less in need of maternal guidance, they will be unusually wcalthy men and women. To say that plaintiffs have been "compensated" for their loss is superficial; in reality they have suffered a loss for which they can never be compensated; they have obtained, instead a future benefit essentially unrelated to that loss.

Borer v. American Airlines, 19 Cal. 3d 441, 447, 563 P.2d 858, 862, 138 Cal. Rptr. 302, 306 (1977).

56. Pearson, supra note 8.

57. Id. at 502 .

58. Pearson himself recoguizes this limitation. Id. at 502-04.

59. G. Calabresi \& P. BobbitT, Tragic Choices 32, 88, 144 (1978). 
tainly pain and suffering awards in wrongful death cases are not meant to improve the state of the injured party's life. ${ }^{60}$

Nevertheless, a systen that awards damages only for pecuniary losses may appear sinply intuitively unfair. ${ }^{61}$ Why should a victim assunie any injuries, alone and uncompensated? Yet the suggestion that awards for nonpecuniary losses are necessary to make a compensatory system fair is inconsistent with the way people generally structure their own compensation schemes. Nonpecuniary aspects of eniotional distress and pain and suffering are only aspects of compensation in legal liability situations. No insurance company offers coverage for pain and suffering on a first-party basis. ${ }^{62}$ Yet the misfortunes covered by first-party fire and health insurance are as likely to involve pain or einotional distress as are any autoniobile accidents. In fact, coverage for such injuries would cost less under first-party than under third-party liability insurance. Apparently, there is insufficient demand for such coverage to motivate any carrier to include an override for physical or emotional distress beyond economic loss. ${ }^{63}$ In addition, surveys show that few successful accident suit claimants knew or cared about payment for pain and suffering. ${ }^{64}$ These factors imply that the concept of just compensation, standing alone, does not compel damages for the noneconomic ramifications of intangible injuries.

\section{Reexamining the Compensation Justification}

This Section has argued that compensation for pain and suffering and eniotional distress should focus on ramifications that are quantifiable and transferable-special/pecuniary rather than general damages. These damages give synibolic recognition to the iniportance of the injured party's bodily and emotional integrity. But they are likely to be limited and provable, and thus less subject to jury discretion. Additionally, they curtail incentives for plaintiff fraud or bill-padding. Of further importance, such daniages can be directed toward the best use of conipensation

60. Such damages are more explainable as an effort to impose costs on the injurer than to compensate the injured party. If general damages for pain and suffering are granted for a surviving victim, to deny such damages if the victim dies would make the tortfeasor better off by killing rather than simply injnring his victim. Both the symbolic and deterrent ramifications of such a result are unacceptable, but the issue is clearly not one of compensation.

61. The simple perception of unfairness appears to have led to the rejection both of severe limitations on damages for psychic injury and of attempts to terminate or cap pain and suffering damages in medical malpractice eases. See, e.g., Wright v. Central Du Page Hosp. Ass'n, 63 Ill. 2d 313, 347 N.E.2d 736 (1976); Carson v. Maurer, 424 A.2d 825 (N.H. 1980); Arneson v. Olson, 270 N.W.2d 125 (N.D. 1978); Simon v. St. Elizabeth Med. Ctr., 355 N.E.2d 903 (Ohio Ct. C.P. 1976).

62. Insurance for psychiatric/psychological care necessitated by trauma is available through most group health insurance plans but only for economic losses. Bell, supra note 8, at 370 n.150.

63. INSURANCE DEP'T OF THE STATE OF NEW YORK, supra note 30, at 26 n.39.

64. O'Connell \& Simon, Payment for Pain and Suffering: Who Wants What, When \& Why?, 1972 U. ILL. L.F. 1, 18-28. 
in these contexts-rehabilitation or making the injured party whole again.

However, as suggested earher, ${ }^{65}$ compensation alone does not justify our tort system. Social insurance would accomplish that goal more fully and simply. For example, compensation interests do not explain why the present system awards damages for intangible injuries in wrongful-death suits nor why defendants remain liable for costs under the collateral source rule even though the plaintiff already has been compensated through some other source such as medical insurance or sick pay. ${ }^{66}$

A more complete rationale for tort law obviously is necessary. There are two distinct issues central to our tort system-whether the victim is entitled to recover and whether the defendant ought to pay. Compensation in tort law creates a paradox: to the extent that damages are truely quantifiable and transferable, any benefit compensation bestows on the original viction is fully offset by the economic harm done to the one who has to pay. One victim is compensated by creating another. From the societal perspective of compensating victims, nothing is gained. ${ }^{67}$ In effect, tort law does not compensate victims; it merely shifts the loss and thus changes the victim's identity. Furthermore, the process of shiftmg the loss is itself costly. An interest other than compensation must exist to justify acceptance of this added shifting cost. ${ }^{68}$

To the extent losses may be shifted, the essential question becomes whether someone other than the initial victim should be burdened and, in essence, become the victim of the accident. The emphasis shifts from what the plamtiff should receive to what the defendant should pay. This noncompensation focus may offer grounds for granting awards greater or lesser than would be required by a singular interest in compensation. The noncompensation concerns of tort law must now be explored.

\section{B. Restitutive Justice}

Restitutive justice has been offered repeatedly as the criterion for

65. See supra text accompanying notes 14-22, 62-64.

66. Professor John Fleming noted almost twenty years ago that:

Tort recovery has thus long ceased to be the only, or even the principal, souree of repairing accident losses, besides the private resources of the victim himself. More typically today, some or all of the losses will have been taken care of by one or more. . . funds long before the injured party gets within the reach of what the slow and cumbrous common-law process may eventually afford him by way of tort damages.

Fleming, The Collateral Source Rule and Loss Allocation in Tort Low, 54 CALIF. L. REv. 1478, 1480 (1966). The mcrease of fringe benefits in collective and private labor contracts, for cxainple, normally assure that medical expenses from illness or accident, howsoever caused, are not borne by the afflicted party.

67. See Lang, Compensation of Victims-A Pious and Misleading Platitude, 54 CALIF. L. REV. 1559, 1559 (1966).

68. O.W. HoLmes, supra note 1 , at 76-78. 
determining who should rightfully bear the burden of accident losses. ${ }^{69}$ From this perspective, tort liability involves a moral appraisal of the individual actor's conduct in each case. Underlying this view is a behef that fairness demands that the blameworthy coinpensate the blaineless. ${ }^{70}$

\section{Theories of Restitutive Justice \\ a. Moral Blameworthiness}

The focus on moral blameworthiness in both tort and criminal law is not surprising since the remedies offered by both were originally administered by the same court in the same action. ${ }^{71}$ Both served to preserve the public peace by offering socially accepted methods for retribution and ventilation of feelings of indignation and resentment. ${ }^{72}$ To the wronged party, insufficient societal response to his injury inight symbolize official indifference and lead him to use violent self-help to satisfy his emotive needs

Although criminal law alone could serve this peace-keeping function, it is often a clumsy and ineffective device for dealing with antisocial activity. Tort law may better redress an array of smaller cases of outrage and oppression which in practice might escape the notice of prosecuting officials occupied with more serious crime. ${ }^{73}$ In addition, because criminal prosecutions are not under the direct control of the wronged party, tort law often offers a more dependable and individually fulfilling option. ${ }^{74}$

69. See ARISTOTLE, Ethica Nicomachea 1131b-1132b (W. Ross trans. 1925); 2 F. HARPER \& F. JAMES, THE LAW OF TORTS $§ 25.1$, at 1301 (1956).

70. During most of the last century and a half, the duty to rectify loss traditionally has not been viewed as based on the fact of mjury alone, but on the conjunction of wrong and harm. See O.W. Holmes, supra note 1, at 64, 105; J. SALMOND, LAW of TORTS 13, 18 (10th ed. 1945); Ames, Law and Morals, 22 HARV. L. REv. 97,99 (1908). Many modern tort scholars continue to recognize the importance of combining wrong with harm im justifying tort liability. See Posner, The Concept of Corrective Justice in Recent Theories of Tort Law, 10 J. LEGAL STUD. 187, 190 (1981); Rosenberg, supra note 23, at 877.

71. W. Prosser, supra note $1, \S 2$, at 8 . Tort damages were first awarded to an injured party as an incident to criminal prosecution. F. POLLOCK, LAW OF TORTS 150 (15th ed. 1951); see also Stat. 5 \& 6 W. \& M., ch. 12.

72. See Ehrenzweig, A Psychoanalysis of Negligence, 47 Nw. U.L. REv. 855, 865-69 (1953). For a full discussion of this function in criminal law, see Ingber, $A$ Dialectic: The Fulfillment and Decrease of Passion in Criminal Law, 28 RutGers L. REv. 861, 863-68 (1975).

73. Punitive damages most specifically play this role by creating imcentives for plaintiffs to serve as prosecuting officers for minor infractions. C. McCoRMICK, supra note 12, at $\S 77 ; 1 \mathrm{~T}$. STREET, Foundations OF LEGAL LIABILITY ch. XXXII (1906); 1 T. SEDGWICK, supra note 12, at § 352, p. 696; Morris, Punitive Damages in Tort Cases, 44 HARV. L. REv. 1173, 1178-79 (1931). When dealing with suits for mental suffering, insult, and indignity, however, the distinction between punitive and compensatory damages is easily blurred.

74. "To pay money to one's victim," Professor Jaffe recognized, "is a salutary lumiliation. The victiin is the focus of the communal sense of having been wronged. The receipt of money particularly from the wrongdoer assuages a justified sense of outrage." Jaffe, supra note 9, at 223. Such a personally foeused remedy is not normally forthcouning from the crininal law system. 
Tort law thus developed as an alternative to criminal law. General damages for pain and suffering served to punish wrongdoers and assuage the feelings of those wronged. ${ }^{75}$ These damages make much sense in this context. They are not designed for purposes of compensation; rather they are intended to assure that the moral wrongdoer receives no costfree pleasure or satisfaction from the suffering of his victim. ${ }^{76}$

Tort law thus has grown with an ostensible focus on "fault." Demands for punishment and the danger of self-help retribution, however, are likely most pronounced when the wrongdoer intentionally or recklessly injures his victim. ${ }^{77}$ In such cases, the defendant's conduct is morally reprehensible and damages are a suitable instrument of punishment. ${ }^{78}$ However, when injuries-especially intangible injuries-are due to negligence, a punishment justification for liability is more difficult to support. ${ }^{79}$

The trend in tort law over the last 150 years has been to distinguish moral wrongdoing from the legal fault of negligence. With the emergence of the objective standard of the reasonable man, ${ }^{80}$ an individual

75. Id. at 222-23; Morris, supra note 36 , at 478.

76. See R. NozICK, ANARChy, State AND Utopia 33 (1974) ("There is no justified sacrifice of some of us for others.")

77. A defendant acts intentionally when he hopes to cause an injury. He acts recklessly when, although realizing his conduct threatens injury to others, he is indifferent to whether the injury actually occurs. Because both types of tortfeasors are consciously acting in a manner likely to cause injury, they will both be treated as behaving willfully.

78. The earliest suits for emotional distress, for example, all involved willful wrongdoing on the defendant's part. See, e.g., Wilkinson v. Downton, [1897] 2 Q.B. 57 (defendant, as a practical joke, told plaintiff that her husband was "smashed up" in an accident); I de S v. W de S, 1348 Y.B. Lib. Ass. f. 99, pl. 60 (tavern keeper's wife dodged hatchet cast by irate customer). These early cases focused more on preserving peace by offering an alternative to self-help retribution than on preserving emotional tranquility. Pearson, supra note 8 , at 486.

Modern tort law and tort scholars have also accepted the legitimacy of damages for willfully caused emotional distress. See, e.g., Enright v. Groves, 39 Colo. App. 39, 560 P.2d 851 (1977) (false arrest of plaintiff); Great Atl. \& Pac. Tea Co. v. Roch, 160 Md. 189, 153 A. 22 (1931) (groceryman, as a joke, places dead rat rather than loaf of bread in package for plaintiff). The classic article on the subject is Magruder, Mental and Emotional Disturbance in the Law of Torts, 49 HARV. L. REV. 1033 (1936). See also Prosser, Insult and Outrage, 44 CALIF. L. REv. 40 (1956); Vold, Tort Recovery for Intentional Infliction of Emotional Distress, 18 NEB. L. BULL. 222 (1939); Wade, Tort Liabllity for Abusive and Insulting Language, 4 VAND. L. REv. 63 (1950). The Restatement (Second) of Torts recognizes a general tort for the infliction of emotional distress only if the defendant's behavior is "outrageous" and "intentionally or recklessly" causes "severe" emotional distress. RESTATEMENT (SECOND) OF TORTS $\S 46$ (1965). Clearly the Restatement's focus is on situational justice and punishment rather than on the preservation of emotional tranquility and compensation. Givelber, The Right to Minimum Social Decency and the Limits of Evenhandedness: Intentional Infliction of Emotional Distress by Outrageous Conduct, 82 Colum. L. REv. 42, 75 (1982).

79. See Friedmann, Principles of Tort Liability and the Growth of Insurance, in INTERNATIONAles VersicheRUNGSRECHT 39 (Möller ed. 1955) (Festschrift für A. Ehrenzweig) (retribution retains its justification in tort law only in a limited sphere where it serves to sanction immoral conduct). See also James, Some Reflections on the Bases of Strict Liability, 18 LA. L. REv. 293, 297 (1958).

80. Vaughan v. Menlove, 132 Eng. Rep. 490 (1837). 
could be found negligent despite bona fide efforts to avoid causing injury to others. Although an individual might well be absolved from moral blaine for injuries caused by an honest blunder, a mistaken behef, or limited intelligence, tort hability would be unaffected. Because neghigencelegal fault-requires nothing more than moinentary inadvertence, the deinand for restitutive justice in such cases is influenced less by moral fault than by rule and expectation violation.

\section{b. Restoration of Order}

Tortious behavior, whether an act of moral turpitude or not, disrupts the existing distributional system of benefits and burdens. Therefore, one of the functions of tort law is to preserve the contemporary sociomoral standards of behavior and thus to protect the status quo. The wrongdoer-whether his conduct is defined by moral, pohtical, or economic criteria-has caused by his rule violation an imbalance in the integrity of the interpersonal arrangements accepted by society. In this context, it seems proper to shift the net loss suffered by society to the rule violator. ${ }^{81}$

Froin this perspective, tort law is indifferent to the moral "rightness" of any given distributional system. Whatever system society has imposed, it has created an expectation that those who act in accordance with the system will be able to preserve their accumulated wealth and values, including health and psychic well-being. If an individual may violate these expectations with impurity, the rule violator in essence would become richer and the rule abider poorer. In such a case, little incentive would reinain to accept the imposed distributional system. Expectations could no longer be developed. Disorder would result.

Tort law reinforces the values of the rule abider. Reparations function as a recognition of the abider's rightful claim to restitutive justice, ${ }^{82}$ justice now defined as fairness and consistency within any given value

81. Professor Calabresi discusses at length this justification for the fault system. G. CALABRESI, supra note 38 , at 301.

82. Restitutive justice, sometimes called "corrective" justice, focuses on the relative distributional positions of wrongdoer and victim before and after a breach of societally fostered expectations or entitlements:

The picture is of a status quo, a base line which the actor disturbs. Behind [this] idea is

Nozick's, Kant's, Locke's conception of a private domain which defines the individual's discretionary space, within which he can work out his conception of happiness. It is the state's, the law's, duty to protect this privacy. ... . If [the boundaries to this private domain are wrongfully crossed by another,] then compensation is due. In other words, compensation is not compelled, [nor] rights protected for forward-looking reasons of the community, but rather just in recognition of those rights. This is what is classically called corrective justice, contrasted to distributive justice or to the pursuit of other policy goals of the community.

Fried, Is Liability Possible?, in 3 The Tanner Lectures on Human Values 91, 120-21 (S. McMurrin ed. 1982) (footnote omitted). 
system. ${ }^{83}$ The violator, in turn, is labelled "responsible" for any loss and burdened with an economic deprivation as a means of making amends. ${ }^{84}$

\section{Restitutive Justice and the Impact of Liability Insurance \\ a. The Demise of Individualized Conflict}

So far, this Section has argued that general damages for intangible injuries are best justified as a means by which wrongdoers or rule violators make amends for their actions and the unpleasant experiences they have caused others. Although the award of such damages is proper when imposed upon a wrongdoer, it is inappropriate when the cost is borne by innocent persons. ${ }^{85}$ Thus, as the emphasis of the tort process shifts from ad hoc pumishment to an orderly distribution of losses, such awards are increasingly less justified.

With the widespread use of hability insurance, ${ }^{86}$ torts may no longer be viewed bilaterally, as simply a method of resolving conflicts among individuals. Insurance funds and compensation plans have transformed tort law into a means of resolving multilateral problems of public policy involving large groups in society. ${ }^{87}$ The bill for intangible injuries is no longer paid only by rule violators or wrongdoers. ${ }^{88}$ Rather, it is borne by a public basically free of fault through insurance funds and pricing mechamsms. ${ }^{89}$ Restitutive justice becomes a fiction when the costs of accidents are shifted not from an innocent to a wrongdoer, but from one innocent to a group of innocents. ${ }^{90}$

83. The concept of justice as fairness is central to much of Rawls' work. See, e.g., Rawls, Justice as Fairness, in JUSTICE AND SocIaL PolicY 80 (F. Olafson ed. 1961).

84. The payment of reparations thus plays a role quite apart from any issue of compensation. G. CAlabresi, supra note 38 , at 301.

85. James, supra note 79 , at 297 ; Morris, supra note 36 , at 476.

86. Insurance need not always take the form of a formal insurance policy. A manufacturer may self-insure by taking the increment in his price necessary to cover the cost of an insurance policy and setting up his own liability pool.

87. W. Blum \& H. Kalven, Public Law Perspectives on a Private law Problem: auto Compensation Plans 8 (1965).

88. Of course the wrongdoer may suffer an increase in his insurance premiums. But the predominant amount of damages he has caused will be borne by all those individuals who have contributed to his insurance pool. The wrongdoer will pay little more than will the multitude of innocents who participate in a common activity.

89. As will be discussed shortly, see infra text following note 92 , this is most problematic when insurance is used to shift the burden of losses away from the morally blameworthy tortfeasor-the willful injurer. This individual may now benefit from his intentional wrongdoing without having to incur significantly greater costs than those borne by innocent members of his insurance pool. But see supra note 88 . This factor accounts for the noninsurability of punitive damages.

90. The advent of insurance has influenced development of the substantive law of negligence. See, eg., Williams v. Williams, 369 A.2d 669 (Del. 1976) (abrogating parent/child immunity); Williams v. City of Detroit, 364 Mich. 231, 111 N.W.2d 1 (1961) (abrogating governmental immunity); Schipper ex rel. Schipper v. Levitt \& Sons, Inc., 44 N.J. 70, 207 A.2d 314 (1965) (establishing liability of house builder for defects).

The decisions in Ybarra v. Spangard, 25 Cal. 2d 486, 154 P.2d 687 (1944); 93 Cal. App. 2d 43, 
As concepts of loss distribution increasingly replace notions of individual responsibility and guilt, all that remains of restitutive justice is the vindication tort law gives the injured person by formally proclaiming the responsible party. The core issue becoines one of inarking the tortfeasor as a wrongdoer. ${ }^{91}$ Where pain and suffering or elnotional distress are involved, however, this labeling can be accomphished without inposing liability for the nonpecuniary impacts of such injuries. This symbolic designation of responsibility requires only that society take sonie meaningful action against the wrongdoer. At least with simple negligence, the deniand for restitutive justice is adequately fulfilled by liniting the tortfeasor's liability to pecuniary costs.

However, both justice and practicality may necessitate liability beyond pecuniary loss to realistically adinonisli individuals who calculatingly risk injury to others. Liability that is limited to pecuniary loss may be insufficient to deter willful tortfeasors from endangering or hurting others. Dainage awards for willful torts slould impose a risk sufficiently high to discourage thein from being viewed by potential tortfeasors as acceptable entertainment or business costs. In this context, general damages for intangible injuries are justified. ${ }^{92}$ Arguments for limiting damages on the basis of fairness or the danger of jury abuse no longer apply because the willful wrongdoer could simply have avoided these consequences by consciously acting not to endanger or cause injury. Any liability risks he confronts have been voluntarily assumed.

Liability insurance thus interferes with restitutive justice by shifting liability away froin the willful inflictor of pain and suffering and enotional distress and placing it upon the innocent masses in the form of insurance premiuuns. Nevertheless, insurance for general damages serves an important function and should be allowed. Without insurance cover-

208 P.2d 445 (1949), may be explained as a reaction to the advent of insurance and the demise of wrongdoer punishment as a justifiable function of tort liability. In Ybarra an unconscious patient undergoing surgery for appendicitis suffered a traumatic injury to his shoulder. Res ipsa loquitur was applied against all doctors and hospital employees connected with the operation, initially to avoid dismissal and, thereafter, to justify liability of all defendants, although it seems clear that all could not have been responsible. Since insurance would spread any judgment among health professionals generally, the need to identify a specific moral wrongdoer was no longer decmed important by the California Supreme Court.

91. Of course, this marking function is less significant when the wrongdoer does not deserve moral blame but merely has becn negligent.

92. In short, willful tortfeasors should not be allowed the advantage of a liability rule of evaluation, but should be subject to property rules. See supra note 16 . The common law has implicitly recognized this need. Damages for willful torts may be made harsher than those for negligent ones by, for example, expressly informing the jury of its option to award exemplary damages, see $\mathrm{C}$. MCCoRMICK, supra note $12, \S 84$; elinnmating contributory negligence; or extending the scope of defendant's duty or the ambit of proximate cause, Bauer, The Degree of Moral Fault as Affecting Defendant's Liability, 81 U. PA. L. Rev. 586, 588 (1933); see also Vosburg v. Putney, 80 Wis. 523, 50 N.W. 403 (1891). 
age, a judgment-proof tortfeasor may feel licensed to injure and his victim may gain as vindication only an uncollectible formal judgment. To avoid this problem, the insurance company liable for the general, nonpecuniary dainages caused by a willful tortfeasor should be allowed to sue him for indemnification or, alternatively, to demand from him a significant surcharge for continued coverage. In this way the victim is assured of his reward while the tortfeasor experiences individualized repercussions for his wrongdoing.

\section{b. Restitutive Justice Within an Insurance Scheme}

Obviously, any effort to develop a danage scheme for intangible injuries must consider the impact of hability insurance on the goals of the tort system. Insurance, to the extent that it associates risks with activities rather than with specific wrongdoers, diminishes the importance of individualized justice as a rationale for tort liability for intangible injuries. In recent years, however, scholars have attempted to develop new moral justifications which are consistent with notions of restitutive justice and account for the trend of associating risks with activities rather than individuals. ${ }^{93}$

One such attempt was imitiated by Professor Robert Keeton who introduced the concept of "conditional fault."94 According to his theory, all those engaged in an activity involving anticipatable attendant risk are morally responsible for the harm caused regardless of the activity's inherent social value. ${ }^{95}$ Those who benefit from an activity must pay all of its costs. Otherwise they are unjustly enriching themselves by expropriating value possessed by their victims. ${ }^{96}$ Professor George Fletcher refined this theory by focusing on behavior that creates a "non-reciprocal risk." 97 According to Fletcher, those participating in such behavior "represent threats of harm that exceed the level of risk to which all members of the commumity contribute in roughly equal shares."98

Keeton and Fletcher's theories retain elements of restitutive justice while simultaneously accounting for the classical concept of strict liability for "ultraliazardous" activities" and the modern insurance industry's

93. R. Rabin, Perspectives on Tort Law 237-38 (2d ed. 1983).

94. Keeton, Conditional Fault in the Law of Torts, 72 HARv. L. REv. 401,418 (1959).

95. Many valuable activities, such as building a skyscraper or a tunnel, will with actuarial certainty take a toll in life and limb. When society permits sueh an activity, it demonstrates a willingness to incur such injuries.

96. Weiler, Defamation, Enterprise Liability, and Freedom of Speech, 17 U. TORONTO L.J. 278, 294 (1967). Cf. Michelman, Property, Utility, and Faimess: Comments on the Ethical Foundations of "Just Compensation" Law, 80 HARV. L. REv. 1165 (1967) (arguing that government is violating the fifth amendinent by not properly coinpensating all the victims of its actions).

97. Fletcher, Fairness and Utility in Tort Theory, 85 HARv. L. REv. 537, 542 (1972).

98. Id. at 547 .

99. Courts have approved the use of strict liability in cases involving: the use of explosives, see 
emphasis on activity liability. Although based upon restitutive justice, these theories easily blend into the purely econounic concept of enterprise liability and a view of tort law as a method of efficient cost allocation. Such cost-allocation theories pose the strongest challenge to the earlier posed suggestions for responding to intangible injuries.

\section{Cost Allocation}

Consideration of economic theory behind tort liability ${ }^{100}$ illustrates how proper allocation of injury costs may decrease the frequency, seriousness, and impact of injury to the individual. It thus provides a perspective vital for developing a model for analyzing intangible injuries.

Through its cost-allocation function, tort law can act to reduce the various costs associated with imjurious activities. The first of these costs are primary costs or the direct costs of the injury itself, as opposed to those associated with the impact of that injury. For example, if an accident results in $\$ 200$ worth of property damage, that loss of value will never be recouped. Although the primary costs of accidents inay be shifted to the tortfeasor, the net social loss is $\$ 200 .{ }^{101}$ The legal system, however, can allocate tort damages to encourage avoidance of these costs. By imposing hability upon those benefiting from the activity that generates primary costs, the legal system increases the cost of participation in such behavior. Increasing the costs of dangerous activities theoretically will reduce the frequency ${ }^{102}$ and the severity ${ }^{103}$ of mjuries. This results from either heightened safety precautions or a reduction in the overall level of the activity. ${ }^{104}$

Forcmg those responsible for accident costs to absorb or "internalize" them also inay lessen these costs by enforcing a more efficient "social cost accounting" in the allocation of scarce resources. ${ }^{105}$ For example, increasing the price of high-risk goods and services-those with high accident costs-may induce consuiners to seek less risky substitutes. Failure to internalize all accident costs, then, amounts to a subsidy for

cases collected in W. Prosser, supra note $1, \S 78$; the possession of dangerous animals, see id. $\S 76$; and the inanufacture and sale of products that typically require consumer reliance upon the manufacturer's and distributor's assurance of product safety, see id. $\$ \S 95,99$.

100. The economic model used is, generally, that developed in G. CalABREsI, supra note 38.

101. If $\$ 200$ is used to restore the damaged property, there is $\$ 200$ less with which to purchase other goods and services.

102. As the cost of an activity increases, individuals may choose to avoid the inore costly behavior or to participate in it inore carefully.

103. Other individuals may choose to take precautions that limit the damage caused by any given accident. Car buinpers, for example, are installed not to prevent accidents, but to reduce the amount of damage caused by the accidents that do occur.

104. G. CAl_ABresi, supra note 38, at 26-28; Pierce, supra note 2, at 1289-90.

105. Calabresi, supra note 1 , at 725 . 
high-risk goods and services, and an indirect subsidy for accidents. ${ }^{106}$ Primary cost avoidance therefore seeks to use the market system to deter the occurrence of injury by allocating the cost to those participating in dangerous activities or best able to prevent mjury by increasing safety measures. ${ }^{107}$

Secondary costs are the post-accident economic consequences associated with an injury. Rather than seeking to reduce the frequency or severity of such injuries, secondary cost avoidance involves allocating injury costs so as to decrease the economic dislocation caused by injuries. Spreading the impact of loss over time or among a class of individuals will decrease economic dislocation, ${ }^{108}$ thereby reducing secondary costs. ${ }^{109}$

106. "[T]he failure to show injury costs means that the prices of the goods the industry sells understate their true costs, and that too much is produced in the industry compared to those which are less accident prone." Calabresi, Some Thoughts on Risk Distribution and the Law of Torts, 70 YALE L.J. 499, 544 (1961).

107. Tort law's use of the market system to discourage injury-producing behavior is known as "general deterrencc." See G. CALABresI, supra note 38, at 68-94. Government could achieve this same goal of primary cost avoidance by controlling specific acts thought to cause accidents. Direct governmental regulation, or "specific deterrence," see id. at 95-129, avoids market processes and relies on collective determinations of the desirability of an activity, of who should participate in it, and of how it should be undertaken. Although general deterrence is far from perfect, see infra text accompanying notes $115-27$, specific deterrence is highly limited. Government would need to obtain detailed information on all activities. Such imformation gathering is costly. Governmental regulation without complete information, however, may be less efficient than leaving risk control to the market, where each industry already knows of its own operation.

Additionally, in a dynamic economy, significant technological and economic changes occur rapidly. See eg., Kasper, Cost-Benefit Analysis in Environmental Decisionmaking, 45 GEo. WASH. L. REv. 1013, 1016-17 (1977). Yet governmental evaluation of every conceivable alternative standard in response to changes in economic and technological factors would be prohibitively expensive. As a result, safety standards rapidly become obsolete. Using tort liability rather than direct regulation has the advantage of encouraging individual firms to devise the best metlood of preventing injury. This approach not only entails less public expense, but also may provide more effective protection by encouraging trial and error experimentation in response to scientific and technological advances.

Finally, as official enthusiasm for governmental regulation ebbs and flows, dependence on specific rather than general deterrence would make public safety captive to political fortunes and the predilections of agency bureaucracies. See Belsky, Environmental Policy Law in the 1980's: Shifting Back the Burden of Proof, 12 Ecology L.Q. 1, 3, $44-45$ (1984); Lovins, Cost-Risk-Benefit Assessments in Energy Policy, 45 Geo. WASH. L. REv. 911,935 (1977); Pierce, supra note 2, at 1314.

108. Spreading accident losses arguably reduces secondary costs in two ways. First, it may reduce economic dislocation. For example, the payment of $\$ 200$ in damages in 20 monthly installments of $\$ 10$ will hikely have less effect on one's life than if the entire sum were payable in full immediately. The second argument is based on the theory of the diminishing marginal utility of money. This theory implies that the loss in utility caused by the sum of small losses, e.g., 10,000 people who each lose one dollar, will not equal the utility loss associated with the loss of one largc sum, e.g., a single individual who loses $\$ 10,000$. See G. CALABresi, supra note 38, at 39. See generally Blum \& Kalven, The Uneasy Case for Progressive Taxation, 19 U. CH1. L. Rev. 417, 45579 (1952).

109. If secondary cost avoidance was the only societal goal, the most effective way to attain it would be a broad form of social insurance for all disabling accidents, or perhaps, for disability from any source. The cost of such insurance could be distributed over society tlirougl general taxation. 
The goals of primary and secondary cost avoidance clearly conflict. Viewing an accident in isolation, as the impact of the accident is reduced through loss spreading (decreasing secondary costs), the incentive to avoid the accident is also reduced (potentially increasing primary costs). ${ }^{110}$ Alternatively, as the impact increases (increasing secondary costs), the incentive to avoid accidents is increased (potentially reducing primary costs). Secondary cost avoidance appears to be inversely related to primary cost avoidance-increases in one will result in reductions of the other. ${ }^{111}$

The widespread use of insurance mitigates the effect of this inverse relationship by associating risks with activities rather than with individuals. When the class participating in the activity that generates the accident internatizes the costs of the accident, the price of that specific accident-prone activity is raised (leading to an incentive for primary cost avoidance), and the cost is spread among all those engaged im the activity (allowing secondary cost avoidance). An ideal system of compensation under this theory allocates accident costs to those activities whose participants can avoid accidents most cheaply but who also are sufficiently numerous to meet adequately secondary cost avoidance goals.

Finally there are tertiary costs associated with the administration of any systen 1 of accident-cost allocation. In developing a model of efficient cost allocation it is necessary to analyze alternative systeins of cost distribution to ensure that the cost reduction from primary and secondary cost avoidance is not consumed by the costs of financing the systen1. ${ }^{12}$ Building on this theoretical background, the renainder of this Section ana-

But, as shall be discussed, see infra note 111, such a broad scheme would have a devastating impact on proper resource allocation.

110. Consequently, the more our compensation system focuses on secondary cost avoidance, the more accidents would have to be controlled collectively. The difficulties in relying on specific deterrence were outlined earlier, see supra note 107.

111. In this light, consider the impact of a system of accident indemnification in which victims are compensated by government through use of funds from the public coffers. By spreading the cost of accidents among all taxpayers, this system would fulfill a high degree of secondary cost avoidance. It also would eliminate, however, virtually all economic imcentives for participants in the accidentproducing activity to limit the frequency or severity of losses. In addition, taxpayers as a class are less able to control automobile accidents than are the classes of those who produce and use automobiles. This process of placing costs on less efficient risk-avoiders and thereby creating a misallocation of resources is called "externalization." G. CALABRESI, supra note 38, at 144-50; see also Vickrey, Automobile Accidents, Tort Law, Externalities and Insurance: An Economist's Critique, 33 LAw \& CONTEMP. Probs. 464, 469-75 (1968).

112. Litigating a negligence suit, for example, is expensive. The effort to determine fault requires such resources as courtrooms, judges, lawyers, investigaters, and witnesses. Even following this investment of resources, the outcome in any given case often remains uncertain. These high litigation costs together with this uncertainty encourage excessively high settlements to avoid the nuisance value of poor or small claims and unfairly low settlements for good or large claims by plaintiffs who have immediate financial needs. Even assuming gocd primary cost reduction, tertiary costs still may make the system economically inefficient. 
lyzes each of these accident costs-primary, secondary, and tertiary-to deterimine the optimal method of responding to intangible injuries.

\section{Primary Cost Avoidance and Deterrence}

Although a number of scholars have questioned whether a rational scheme of deterrence would be structured to be imitiated only by the "fortuitous materialization" of accidental harm, ${ }^{113}$ even those who criticize the role of deterrence in tort law recognize it as one of the system's fundamental aspirations. ${ }^{114}$ For primary cost avoidance to function successfully, however, an assumption of econounic rationality must prove accurate and two core probleins of cost allocation must be resolved. I will broadly discuss these practical concerns and then relate thein specifically to the question of intangible injuries.

\section{a. Practical Considerations}

Tort law presumes that individuals will respond to economic pressure to reduce their costs. ${ }^{115}$ There is, however, no irrefutable evidence to prove this assumption. ${ }^{116}$ Many parties are unable to control future costs because they lack the information or ability to predict accident costs. ${ }^{117}$ Moreover, an individual's conscious choice plays a relatively insignificant part in causing or preventing accidents because of the inevitability of a substantial portion of human error. ${ }^{118}$ As Professor Cornelius Peck has noted, "[t]he concept that liability for daunages deters parties from dangerous and harmful conduct is of limited applicability to cases involving unintended consequences." 119 On the other hand, there

113. Weiler, supra note 96 , at 290 . For such critics the degree of deterrence appropriate should be a factor of the seriousness of the involved antisocial conduct rather than the "fortuitious character and magnitude of the harm caused." Id. See also W. BLUM \& H. KALVEN, supra note 87, at 13.

114. See, e.g., Rodgers, Negligence Reconsidered: The Role of Rationality in Tort Theory, $54 \mathrm{~S}$. CAL. L. REV. 1 (1980).

115. See, e.g., P.S. ATtYAH, supra note 25, at 557; G. CAlABRESI, supra note 38, at 69; L. Friedman, The Legal System: A Social Science Perspective 135-36 (1975); R. PosNer, ECONOMIC ANALYSIS OF LAW 4, 143 (2d ed. 1977).

116. There is some limited empirical evidence that tort law may effectively deter. See AMERICAN BaR Ass'n, Automobile No-Fault InSURANCE: A STUdy by the SPECIAL Committee ON AUTOMOBILE INSURANCE LEgISLATION 11-12 (1978). If people do not respond to economic incentives, tort law will not accomplish primary cost avoidance.

117. G. CALABrESI, supra note 38, at 224-25. Such mdividuals have high "transaction costs"costs which must be overcome before any effective action will be taken. See generally Calabresi, Transaction Costs, Resource Allocation and Liability Rules-A Comment, 11 J.L. \& EcoN. 67 (1968).

118. See the studies of aceident-producing behavior assembled in James \& Dickinson, Accident Proneness and Accident Law, 63 HARV. L. REV. 769 (1950). In any case, individuals often have the greatest imcentives to be careful quite aside from considerations of civil liability. James, Accident Liability Reconsidered: The Impact of Liability Insurance, 57 YALE L.J. 549, 558 (1948).

119. Peck, Compensation for Pain: A Reappraisal in Light of New Medical Evidence, $72 \mathrm{MICH}$. L. REV. 1353, 1373 (1974). One inay remain skeptical of the deterrent impact even on willful 
is evidence that the threat of liability is most effective in accident prevention when it focuses not on situational wrongdoing but on categories of activities ${ }^{120}$ and on large economic units such as industrial, transportation, or insurance companies. ${ }^{121}$

Even assuming that civil liability may influence behavior, two serious problems remam. First, all mjuries are likely to involve two or more activities or classes of behavior. ${ }^{122}$ Consequently, to accomplish the goals of cost allocation, the legal system must first determine properly which of the involved activities generated the injury and thus must internalize injury costs. This determination, however, is neither scientific nor policy-free. ${ }^{123}$ The process of selection is value-oriented, dependent on the goals we wish to achieve and the means we think are best to accomplish them. ${ }^{124}$ Liability is not only a matter of just deserts but a forward-

tortfeasors because of the potential muting effect of insurance. See, Brown, Deterrence and Accident Compensation Schemes, 17 U.W. ONT. L. REV. 111, 115 (1979); Pierce, supra note 2, at 1294-99. But see James, supra note 118, at 561-62 (liability insurance has not been responsible for any increase in accident rate).

120. For example, liability will more likely influence the choice of whether one transports goods by car, truck or air than whether one drives carefully.

121. The data show, for example, that large manufacturers make greater safety investments than small ones do. See INTERAgency TASK ForCE ON PROD. LIAB., Final REPORT IV 47 to -48 (1978). See also id. at IV-4, $-12,-19$ to -20 . Moreover, studies have been able to demonstrate a correlation between safety measures taken and insurance premiums only in cases of very large firms and a few common products. Pierce, supra note 2, at 1299.

Ironically, a threat of liability that focuses on large economic umits, while increasing the likely deterrent effect of liability, also attenuates the extent liability can be viewed as a response to moral blameworthiness.

122. An automobile-pedestrian accident, for example, involves the activities of auto transportation and walking the streets. A lawnmower accident involves the activities of manufacturing and lawnmowing.

123. Morris, Enterprise Liability and the Actuarial Process: The Insignificance of Foresight, 70 YALE L.J. 554, 590 (1961). Morris argues that:

The causation argument, after all, rehies upon the concept of risk, rather than the concept of physical causation. The question then becomes: What institutions have the duty to minimize risk? The taxicab company placed its cab upon the street, as it had the undoubted right to do. The houseliold permitted the child to play near the street, which was also proper. But both of these practices increased the risk. The allocation of the loss to one or the otlier of these institutions involves more than finding the risk-incrcasing institution; it involves a judgment as to which of the two has the greater duty to reduce risks. It appears, therefore, that the general consensus in this area is determined not only by factual observations of risk imcreasing beliavior, but also by our judgment concerning both the capabilities and proper role of the institutions involved. This judgment both dictates our goals and limits our sense of relevancy.

Id. Cf. Malone, Ruminations on Cause-in-Fact, 9 STAN. L. REv. 60, 61-64 (1956) Malone argues that a cause is not a fact in the seuse that its existence can be established inerely through the production of testimony. Determining cause requires a variety of intellectual functions peculiar to the trier of fact. $I d$.

124. This realization may explain why occasionally all the costs associated with an accident are not absorbed by a single activity. For example, the loss of jobs due to a tortiously started fire inay be handled more efficaciously through unemployment insurance. This is so even though we may wish to deter the tortfeasor by having him compensate for the damaged building. Consider also the New York fire rule, see supra text accompanying note 20 , according to which the tortfeasor need only 
looking attempt to allocate costs so as to develop patterns of conduct that promote safety. ${ }^{125}$

Second, the amount internalized by any activity inust represent an accurate accounting of accident costs. Iinproper internalization by a given activity would distort the deterrent effect of tort liability and lead to misallocation of resources. Such distortions may result, for example, where injured parties fail to sue or effectively prosecute their claims, ${ }^{126}$ or where they make claims that lack any meaningful inethod of accurate accounting. Consequently, when one combines "[t]he difficulty of calculating social costs, of evaluating noneconomic costs and benefits, [and] of allocating different costs to different activities ... [ [the result is] that general deterrence can usually only operate in a rough and ready way at

compensate the owner of the first building destroyed even though the fire spreads to a second one. The belief that destruction from fires-negligent or otherwise-may be minimized through fire prevention efforts in the construction and maintenance of buildings suggests that costs beyond the damage to the first building may best be imterualized in those activities.

125. Weiler, supra note 96 , at 304 . Three general methods have developed for allocating costs:

(1) Strict liability allocates cost without any determination of fault. Instead, it seeks to determine which categories of behavior involve actors best able to make a cost-benefit analysis between mjury costs and injury avoidance costs and to act upon that analysis. See Calabresi \& Hirschoff, Toward a Test for Strict Liability in Torts, 81 YALE L.J. 1055, 1060 (1972). Each activity must interualize the costs it generates so as to encourage future safety, mitigate impact through spreading, and allow the market to determine accurately the distribution of resources between risk-prone and risk-limited endeavors. See W. ProssER, supra note $1, \S 175$, at 494-96.

(2) The negligence system employs the courts to choose between injury costs and injury-avoidance costs. Theoretically, the factfinder inay inpose liability on the defendant only if the benefits of avoidance are greater than the costs of avoidance. See Conway v. O'Brien, 111 F.2d 611, 612 (2d Cir. 1940) ("The degree of care demanded of a person by an occasion is the resultant of three factors: the likelihood that his conduct will injure others, taken with the seriousness of the injury if it happens, and balanced against the mterest which he must sacrifice to avoid the risk."), rev'd on other grounds, 312 U.S. 492 (1941). The entire focus of a negligence standard of liability, therefore, is primary cost avoidance in the specific case. Liability exists only for accidents that are cheaper to avoid than to allow.

A system based on a negligence standard thus involves a case-by-case analysis to determine whether the parties acted properly. It focuses on the individual behavior of actors involved in a unique event, while strict hability focuses on injuries predictably generated by general types of activity. As suggested earlier, an emphasis on the unique, when combined with the impact of insurance, is less likely to result in effective deterrence. Furtlier, case-by-case analysis involves substantial administrative expense-tertiary costs-thereby both potentially deterring legal action by deserving plaintiffs and increasing the possiblity of nuisance suits.

(3) The final allocation system is liability for willful acts. Because the defendant has deliberately threatened injury to another, willful torts most casily justify the imposition of liability. The defendant is the best cost-benefit analyst simcc he already is aware that he threatens injury. Because his actions are considered, the possibility of tort damages is most likely to influence his behavior and least likely to discourage or disrupt societally valued activities.

126. This failure on the part of legitimate claimants to pursue their claims may be due to dificulty in proving fault or causation, expense of tort litigation, availability of compensation from other sources, existence of a judgment-proof tortfcasor, belief that it is wrong to sue unless the defendant did something "bad," or ignorance that the injury was caused by a third party or that tort compensation is even available. Pierce, supra note 2 , at 1295-96. 
best."127

In short, tort law may be a better means than social insurance to compensate victims because of its ability to effect primary cost avoidance. The central concern shifts from adequate compensation to proper internalization. It is not what needs to be collected but what needs to be paid. ${ }^{128}$ Cost allocation for intangible injuries must therefore be considered from this perspective.

\section{b. Impact on Intangible Injuries}

Primary cost avoidance arguments strongly support the propriety of general damage awards to cover the nonpecuniary costs of intangible injuries. ${ }^{129}$ Unless the full costs of physical and emotional distress are properly internalized through tort law, the price of the activities that generated such injuries will insufficiently reflect their actual costs. In effect, victims or the public would subsidize the cost of high-risk activities, thereby leading to inadequate deterrence ${ }^{130}$ and resource misallocation. From this perspective, full reparation for intangible injuries is desirable whether or not true victim compensation is possible. As stated earlier, ${ }^{131}$ however, this market-based deterrence process works only if the costs are properly placed and accurately valued. These requirements, generally problematic, have their difficulty compounded when the issue is intangible injuries.

To the extent that intangible injuries are truly nontransferable, imposing liability burdens the defendant with the costs of an injury that the plaintiff nevertheless must bear. ${ }^{132}$ There is essentially a "double accounting" in sucli cases that may present a danger of excessive avoidance and a concomitant misallocation of resources. ${ }^{133}$ In determining

127. P.S. ATIYAH, supra note 25, at 612 .

128. Fletcher, supra note 97, at 540-42; Vickrey, supra note 111, at 465-69. This view of tort law's intended function more fully explains the legal system's acceptance of the collateral source rule and awards for pain and suffering or emotional distress in wrongful death suits, neither of which is easily explicable as outgrowths of compensation concepts. See supra text accoinpanying notes 65-66.

129. For the most comprehensive discussion of the primary cost avoidance argument for full compensation of intangible injuries, see Bell, supra note 8, at 347-62.

130. These costs, not internalized by the defendant, will be borne by the plaintif. High transaction costs, however, may interfere with the victim's ability to self-protect. See infra text accoinpanying notes 147-48.

131. See supra text accoinpanying notes $122-27$.

132. Pain or emotional distress remains unshifted from the victim, motivating him to redirect his behavior so as to avoid such future injuries. Granting monetary damages would force the injurer also to suffer loss and redirect behavior. G. CALABRESI, supra note 38, at 218.

133. As suggested earlier, tort law does not seek to avoid injury at any cost. See supra notes 95 , 124-25; see also supra text accompanying notes 108-11. Liability for negligent acts, for exanple, attaches only when the cost of avoidance is low enough to inake nonavoidance unreasonable. An excessive amount of accident avoidance inay be highly dysfunctional. This is particularly important in the fields of defanation and privacy where the potential chilling effect on the press caused by tort liability is an inportant concern. See infra text accompanying notes $259-68,342-43,380-83$. 
which activity generated the injury and therefore should internalize its costs, one must be careful to avoid excessive deterrence that may unduly restrict a useful, but risky activity.

A traditional argument against hability for emotional distress is that the mjury is due more to the predisposition of the injured party than to the behavior of the defendant. ${ }^{134}$ Proponents of this view argue that the cost of the imjury should be borne by the plaimtiff himself. Indeed, even supporters of full compensation for emotional distress acknowledge that "[a] person's pre-existing psychological state unquestionably plays a significant role $\mathrm{m}$ determining the nature and extent of his response to trauma." 135 Given the nonscientific nature of "causation" as used in tort law, ${ }^{136}$ it is reasonable to question whether in these circumstances the defendant's actions alone "caused" the injuries claimed.

Although the predisposition of a plamtiff to injury may be more obvious in cases of emotional distress, different individuals may also be able to tolerate varying levels of pain and suffering from physical injury. Recent hiterature on pain strongly suggests that the relationship between injury and pain inay not be as direct as tort law assumes. ${ }^{137}$ Research by Doctors Ronald Melzack and P.D. Wall, for example, produced a radically different model for the psychological control of pain.

[I]t is important to recognize the role of cognitive or "higher central nervous system" activities such as anxiety, attention, and suggestion in pain processes. The model suggests that psychological factors such as past experience, attention, and emotion influence pain response and perception. . . . ${ }^{138}$

Thus, physical pain as well as emotional distress may be as much a function of the plaintiff's individual characteristics as of the defendant's behavior.

Furthermore, the same physical or emotional pain stimulus may

134. For example, consider the facts of Yandrich v. Radic, $495 \mathrm{~Pa} .243,433$ A.2d 459 (1981), where plaintiff committed suicide after the defendant negligently killed lis son in an automobile collision. Prior to his son's accident, however, three of the plaintiff's very young children died when his car rolled into a reservoir and sank with the unattended children inside. His wife had also died previously. These prior events obviously had affected plaintiff's emotional makeup. Should the defendant absorb the costs of this wrongful death action? Other cases pose similar factual patterns. See, e.g., Gross v. United States, 508 F. Supp. 1085 (D.S.D. 1981), aff'd in part, vacated in part, 676 F.2d 295 (8th Cir. 1982); Deziel v. Difco Laboratories, Inc., 403 Mich. 1, 268 N.W.2d 1 (1978); Wolfe v. Sibley, Lindsay Curr Co., 36 N.Y.2d 505, 330 N.E.2d 603, 369 N.Y.S.2d 637 (1975).

135. Bell, supra note 8, at 357 n.97. One study of individuals who were awarded damages for entotional distress found that in 216 of 301 cases, the plaintiff had a preexisting vulnerability which probably nuade him more susceptible to the type of injury alleged than would be an average person. Smith, Relation of Emotions to Injury and Disease: Legal Liability for Psychic Stimuli, 30 VA. L. REV. 193, 282 (1944).

136. See supra text accompanying notes 122-25.

137. Peck, supra note 119 , at 1367-68.

138. Melzack \& Wall, Psychophysiology of Pain, 8 INT'L ANEsthestology Clinics 3, 30 (1970). 
incapacitate some people and be only a minor annoyance to others. For example, persons experiencing the same emotional trauma-such as witnessing the death of a child in an accident-may equally react with fear and alarm. But then their defense mechanisms will be called into play to resist the innpact of the trauma. Depending on their ego strength, problem-solving ability, flexibility, and social skills, they will be more or less successful in assimilating that impact. ${ }^{139}$ Factors unique to the individual are thus at work in both the physical and emotional pain contexts. Yet, this very uniqueness of an individual's response to an injury was considered earlier as a possible justification for sontetinnes requiring that the individual bear lis own loss. ${ }^{140}$

At some poimt the reaction of the specific individual becomes sufficiently idiosyncratic and unexpected as to be "unreasonable."141 In sucli cases an individual distressed by an occurrence that most otliers would perceive as nontraunatic is required to bear the burden of his own fragile sensibilities. ${ }^{142}$ Otherwise eacli of us would have to conform our behavior to the needs of the most unstable in our midst. ${ }^{143}$ Consequently, lia-

139. See Jenkins, Psychosocial Modifiers of Response to Stress, 5 J. Hum. STREss 3, 4-5 (Dec. 1979).

140. See supra text accompanying notes 15-19.

141. I have argued elsewhere that "irrationality" may be defined in terms of the unexpected or unpredicted. Ingber, supra note 72, at $892 \mathrm{n} .157$. Individuals whose behavior we can neither predict by use of our own cultural expectations nor explain through the individual's identification with another culture are dismissed as irrational. A similar explanation can justify the use of the label "unreasonable."

142. See Spade v. Lynn \& B.R.R., 168 Mass. 285, 47 N.E. 88 (1897) (drunk man lurches toward a woman on a inoving street car).

Not only the transportation of passengers and the running of trains, but the general con-

duct of business and of the ordinary affairs of life, inust be done on the assumption that persons who are liable to be affected thereby are not peculiarly sensitive, and are of ordinary physical and mental strength.

... [A]s a general rule, a carrier of passengers is not bound to anticipate or to guard against an injurious result which would only happen to a person of peculiar sensitiveness. Id. at 89 .

The general rule does not apply, however, when a defendant intentionally disturbs or distresses soineone known to be unreasonably sensitive or vulnerable. See, e.g., Clark v. Associated Retail Credit Men, 105 F.2d 62 (D.C. Cir. 1939); Alcorn v. Anbro Eng'g, Inc., 2 Cal. 3d 493, 468 P.2d 216, 86 Cal. Rptr. 88 (1970); Richardson v. Pridmore, 97 Cal. App. 2d 124, 217 P.2d 113 (1950); Korbin v. Berlin, 177 So. 2d 551 (Fla. Dist. Ct. App. 1965), cert. dismissed, 183 So. 2d 835 (Fla. 1966); Delta Fin. Co. v. Ganakas, 93 Ga. App. 297, 91 S.E.2d 383 (1956); Nickerson v. Hodges, 146 La. 735, 84 So. 37 (1920); Continental Casuaity Co. v. Garrett, 173 Miss. 676, 161 So. 753 (1935). Otherwise we would have the intolerable situation of an individual's being able to take dehberate advantage of another's idiosyncrasies and then to demand insulation from suit because the victim's reaction was somehow "unreasonable." W. PROSSER, supra note $1, \S 12$, at 58; $c f$. RESTATEMENT OF TORTS $\S 538(2)(b)$ (1938) (when a representation is intended to deceive, it is considered material if the maker knows the recipient is peculiarly disposed to regard it as important, even though a reasonable man would not do so).

143. Dr. Hubert Smith concludes:

It is both just and expedient to require the frail fellow who ventures out into the world to assume such special risks of injury from every day stimuli as arise from his idiosyncrasy. He knows better than uninformed strangers how to protect his weakness by sheltering his 
bility is justified only if the defendant's behavior was such as to foreseeably cause emotive or physical distress of some noticeable level to an individual with normal sensibilities in the plaintiff's position. ${ }^{144}$

The more common case, however, does not involve basically innocent defendant behavior that unforeseeably causes harm to the ultrasensitive plaintiff. The more frequent context involves behavior which would foreseeably cause damages or at least discomfort in an ordinary person. Here, it is the mtensity of the plaintiff's reaction and the incapacity that it causes that are beyond normal expectations. Full recovery for these unanticipated effects would seem consistent with the traditional doctrine that one takes his victim as one finds him. An acknowledged tortfeasor is ordinarily not exculpated from liability for untoward consequences peculiar to a plaintiff with a preexisting susceptibility. ${ }^{145}$

The so-called "thin-skull plaintiff" rule ${ }^{146}$ is subject to criticism because it places upon the defendant costs that are as much an outgrowth of plaintiff's life history as of defendant's conduct. ${ }^{147}$ The justification for the rule, however, is simple: the fact that the plaintiff was predisposed to such injury does not mean he could easily have avoided it. Prior to the injury, the plaintiff may have been unaware of his predisposition. Alternatively, the cost of avoidance may simply have been so great as to preclude protective efforts on his part. ${ }^{148}$ If the choice is total liability for the defendant or total burden for the plaintiff, it seems inore equitable to place the accident costs on the defendant.

Achilles heel. As most persons possess average hardihood and resistance, an actor is entitled to expect that a particular person within his sphere of action has normal fortitude unless he has notice to the contrary.

Smith, supra note 135 , at 256.

144. This standard was accepted by the Califormia Supreme Court in Molien v. Kaiser Found. Hosps., 27 Cal. 3d 916, 616 P.2d 813, 167 Cal. Rptr. 831 (1980).

145. If a playful kick can make one schoolboy liable for the unforeseen resulting infection in the leg of his diabetic playmate, may not certain statements just as legitimately place upon the utterer the risk of triggering a neurosis or physical illness in a predisposed individual? Probert, Defamation, A Camouflage of Psychic Interests: The Beginning of a Behavioral Analysis, 15 VAND. L. REV. 1173, 1183 (1962) (comparing hability in defamation for injury to a predisposed individual to the facts found in the battery case of Vosburg v. Putney, 80 Wis. 523, 50 N.W. 403 (1891)).

146. For a discussion of the rule, see Steinhauser v. Hertz Corp., 421 F.2d 1169 (2d Cir. 1970).

147. Professor Peck insists that the doctrine of taking one's victim as one finds him is inapposite to cases involving intangible injuries. That doctrine requires that the plaintiff have a preexisting physical or mental condition. But according to Peck, the physical and emotional pain following an accident likely may be experienced "because family, work, or other social factors lead the victim subsequently [to the accident] to adopt a life of chronic pain." Peck, supra note 119, at 1388. If pain is a response to the victim's post-accident environment, the "thin skull" comparison is inapt.

148. Consider again the previously discussed example of an injured concert violinist. See supra note 19. When injured by a speeding auto, he may claim lost income due to the injury of his unusually talented hands. The defendant, therefore, may be liable for costs far beyond those resulting from ordinary hand mjuries. The alternative, however, would be to penalize the violinist for living a normal life, for example, walking on the public sidewalk or properly driving his car. By placing thc full burden of the injury on the tortfeasor, presumably he is encouraged to drive more responsibly. 
However, proper cost allocation of intangible injuries need not be perceived as an all-or-nothing proposition. By requiring the defendant's activity to internalize only pecuniary and transferable costs, the danger of double accounting and the problem of the predisposed plaintiff are avoided. ${ }^{149}$ Such a system also would place upon the defendant a major financial incentive to avoid engaging in activities likely to cause pain and distress. The general damages to be borne by the victim serve as formal recognition that the severity of the victim's injuries is due in part to his life experience generally. The subjective and nontransferable nature of general damages makes them inost suited to serve this symbolic function.

In addition to the danger of misplaced damages, the nonquantifiable nature of intangible injuries makes cost internatization for primary cost avoidance purposes unrehiable. Considerable variations in damage awards for such injuries make any likelihood of an "accurate" cost evaluation and "proper" resource allocation a matter of blind faith. ${ }^{150}$ Yet without any market yardstick against which to measure their judgments, juries, usually sympathetic to the plaintiff's plight, ${ }^{151}$ have unfettered discretion to determine the extent of damages. Not surprisingly, damages for pain and suffering are typically greater than for economic loss. ${ }^{152}$

149. Of course the individual so susceptible to emotional distress that he is injured where others would not be at all should have no cause of action even for pecuniary loss. See supra text accoinpanying notes 141-44.

A more significant problem with this proposal is created by the individual who, although foreseeably injured, simply enjoys going to psychiatrists or psychologists. There is little disincentive under tle proposed system for either these plaintiffs or their therapists to avoid potentially excessive or unneeded treatment.

Although this criticisin is justified, it also inay be directed at the present system to the extent we already compensate for einotional distress. The proposed system may at least mitigate this danger by lessening the opportunity for financial gain from plaintiff fraud. More importantly, however, any system of compensation for mental health services runs the risk of erring by creating either too great or too sinall an incentive for injured parties to seek help. In a system that limits the risk of fraud, I would opt for the risk of too inucl help over too little. Additionally, the use of conservatorships and trusts discussed earlier, see supra text preceeding note 52, may further reduce this danger.

150. Some authors concerued witl arbitrary jury judgments for pain and suffering have suggested developing a dainage scliedule for such injuries. See, e.g., Zelermyer, supra note 26, at 41. Schedules of average or base pain and suffering dainages could be inodeled after those used in workmen's compensation. Beyond that point, further pain and suffering costs would remain witl the injured party under the theory of allocating highly individualized damages to the victim. Other scholars have suggested that the rigidity of workmen's compensation scheduling inakes sucl a model unattractive. W. BLum \& H. KALVEN, supra note 87, at 25. See generally Riesenfeld, Basic Problems in the Administration of Workmen's Compensation, 36 MiNN. L. REv. 119 (1952).

151. See 2 F. HARPER \& F. JAMES, supra note 69, § 15.5, at 892-95; W. ProssER, supra note 1 , \$ 37, at 208; Franklin, Good Names and Bad Law: $A$ Critique of Libel Law and a Proposal, 18 U.S.F.L. REv. 1, 7 (1983); Nixon, Changing Rules of Liability in Automobile Accident Litigation, 3 LAw \& CONTEMP. ProBs. 476, 477 (1936). Sucli bias is understandable. In the drama of trial, the plaintiff appears crippled, broken, or misused. The jury's sympathy is aroused. The plaintiff bears the pain, luuniliation, and disappointınent. Why, questions the jury, sliould not the defendant, who is known to be actually an insurance company, at least bear the economic mipact?

152. INSURANCE DEP'T OF THE STATE OF NEW YORK, supra note 30, at 26. 
Any system of risk allocation that increases the role of juries-as hability for intangible injuries necessarily does-increases the parties' uncertainty regarding the systen's likely outcoine. The litigant who feels most threatened by such uncertainty probably also feels the strongest pressure to settle. Consequently, while the rise in damages for intangible mjuries has received the greatest publicity in the few cases in which enormous amounts have been awarded, it has had its inajor effect upon the pattern of compensation awards in the inuch inore numerous cases in which smaller amounts have been recovered. ${ }^{153}$ In small cases, the certainty gained by setthing a claim typically is worth more to the insurance company than to the claimant. Consequently, small claims tend to be overpaid. In such cases the excess over economic loss is usually called "general" dainages or "pain and suffering." 154 However, in large cases where severe disability exists, the injured party may desperately need immediate compensation to cover his pecuniary needs and losses. ${ }^{155}$ In such cases, certainty is usually worth more to the claimant than to the insurance company. Large claims therefore are often grossly underpaid. ${ }^{156}$

In short, the present system of "full" compensation for pain and suffering is defective because it often undercompensates severely injured parties and overcompensates parties with relatively small econounic losses. To the extent that compensation does not accurately reflect the

153. Most liability cases are settled and thus never get to court.

154. American MUt. Ins. AllianCe, Statement on Automobile ACCident law and automobile Insurance 10 (1969); A. Conard, J. Morgan, R. Pratt, C. Voltz, \& R. Bombaugh, Automobile ACcident Costs AND PAyments: StUdies in the ECoNomics of INJURY REPARATION 197 (1964) [hereinafter cited as AUTOMOBILE ACCIDENT Costs].

155. National ASS'N OF INS. COMM'rs, Automobile Insurance Study Background Memorandum, in Report of the Special Committee on Automobile Insurance Problems 99-100 (1969).

Those who have suffered injuries in automobiles know that prompt payment of compensation is rare, and that the gap between loss and compensation is vast. . . .

The long delays, cliaracteristic of this system, produce a cruel injustice that strikes larder as injuries are more severe. A hard bargaining insurance company can buy the claim of such a person with a penurious settlement offer that capitalizes on his pressing needs in face of a long wait for trial.

Investigation of Auto Insurance: Hearings on S.J. Res. 129 Before the Consumer Subcomm. of the Comm. on Commerce, 90th Cong., 2d Sess. 180-81 (1968) (statement of the Executive Board of Communications Workers of America).

156. "If there is one thing which the surveys have shown conclusively," reports Professor Alfred Conard, "it is that the tort system overpays the small claimants who need it least, and underpays the large claimants who need it most." Conard, Testimony Before the New York Joint Legislative Committee on Insurance Rates and Regulations, U. Mich. L. QUADRANGLE NOTES, Fall 1970 , at 15.

One sucl study found that of the accident victims with the largest economic loss, $71 \%$ received one-quarter or less of their econonic loss through the tort system-because they settled. Automo. BILE ACCIDENT COSTS, supra note 154, at 197; see also AMERICAN BAR Ass'N, REPORT OF THE Special Committee on Automobile Accident Reparations 104 (1969). 
"true" cost of the injury, the goals of primary cost avoidance are frustrated. A system that limits liability to the pecuniary effects of intangible injuries would effectively regulate juries and would eliminate concerns about nuisance suits. ${ }^{157}$ Except where the tortfeasor willfully attempts to cause another pain and suffering, ${ }^{158}$ the primary cost avoidance goals of tort law are not necessarily better served by "full" liability for intangible injuries than they would be under a more refined damage model.

\section{Secondary Cost Avoidance and the Reduction of Impact}

So far, my analysis of cost allocation has suggested only that full compensation for intangible injuries may not reduce the social cost of accidents. I have not yet considered whether such compensation serves secondary cost avoidance goals of affecting the impact of such injuries by making the class of potential victims-the "sensitive" within our midstricher and the class of potential injurers-the "aggressive" within our midst-poorer. It is questionable, however, whether recognizing liability for pain and suffering and emotional distress has this effect or mitigates these injuries at all. In fact, the legal recognition of such damages may aggravate the injury for those suffering.

First, limiting damages for intangible injuries to pecumary and transferable costs may imdirectly result in more effective utilization of insurance. As previously noted, allowing general damages for intangible injuries encourages frequent settlements with compensation for intangible injuries going most to those who suffer least and least to those who suffer most. ${ }^{159}$ Smaller injuries absorb a disproportionate amount of insurance compensation for intangible injuries. Consequently, the miniinum value of small claims tends to be very high. This causes liability

157. See supra text accompanying notes 51-52. Such a system, however, might also reduce the pressure on defendants to settle claims fairly. This danger and a method to avoid it are discussed later in this Article. See infra text accompanying notes 190-92.

158. The goal of dissuading the willful tortfeasor is sufficiently strong to counterbalance any fear of misplacing or misevaluating the costs of intangible injuries. In such cases a property rule of evaluation is appropriate. See supra note 92 and accompanying text. Consequently, the jury bias toward the plaintiff and the danger of higher damages is consistent with the tort process' purpose of deterring the willful tortfeasor by removing any benefit for his misdeed that he might consider worth the resultant cost.

159. See supra text accompanying notes 153-56. A Department of Transportation study of auto insurance shows that Americans who suffered the most pecuniary loss received relatively little from tort claims. According to the study, approximately $60 \%$ of those who suffered economic loss of $\$ 10,000$ or more receiveed nothing from tort claims; among those with more than $\$ 10,000 \mathrm{~m}$ pecuniary loss who received something from a tort claim, over $95 \%$ received less than their pecuniary loss; $85 \%$ received less than half their pecuniary loss and only $0.6 \%$ received more than twice their loss. 1 United States DeP'T of Transp., Economic Consequences of Automobile Accident INJURIES, Table 25 FS., at 235 (1970). At the other end of the spectrum, among those with pecuniary loss less than $\$ 1,000$ who received tort payments, none received less than half their loss; $87 \%$ received more than their loss, $41 \%$ received more than twice their loss, and $14 \%$ received at least four times their loss. Id. 
insurance with low limits to be very costly. ${ }^{160}$ Thus, in states that require insurance coverage as a condition for participating in certain activities, such as driving, individuals often carry only the mandated minimums. ${ }^{161}$ Tle severely injured plaintiff, therefore, may find that his award quickly exceeds the policy limits of an otherwise judgment-proof defendant. ${ }^{162}$ Consequently, those inost in need of mitigation may find tlieinselves undercompensated and forced to largely absorb the pecuniary burdens of their injuries themselves. ${ }^{163} \mathrm{~A}$ decrease in general damages for intangible injuries inay significantly lower imsurance costs, thereby enabling people to purcliase greater insurance coverage. Therefore, a reduction in intangible injury costs actually inay result in greater mitigation of tlie pecuniary mipact of accidents on the severely injured.

Not only inay tlie granting of general damages for intangible injuries increase tlie burden of pecuniary losses on the severely damaged, but, ironically, such recoveries inay even prolong or intensify the physical or emotional suffering of accident victims. ${ }^{164}$ An individual seeking damages for intangible injuries in a personal-injury suit typically is encouraged to focus on his suffering, to preserve, nurture, and memorialize every vexation and twinge of pain. ${ }^{165}$ Yet such concentration on one's suffering inay be contrary to sound medical practice, which encourages tlie victim to quickly put the accident or traumatic event belind him and strive to return to a nornal life. ${ }^{166}$ Extended litigation may well prolong or renew the plaintiff's suffering as he is compelled to repeatedly

160. This high insurance cost will be reflected, of course, in the general cost of living. Its impact, like that of a regressive tax, thus will be felt most by the poor in our society through their purchases of goods and services.

161. R. Keeton \& J. O'ConNell, Basic Protection for the Traffic Victim 109 (1965). Low compulsory insurance himits are understandable because states do not wish to price their citizens out of vital activities such as driving.

162. Most telling, those foreign systems that have limited or rejected intangible damages for accidents tend to have no insurance limits on liability coverage. O'Connell, supra note 31, at 340.

163. One method of reducing the financial drain on the tort system of small claims might be to require a set deduction of $X$ thousands of dollars before one could collect on an award for general pain and suffering. In a similar vein, the Uniform Motor Vehicle Aceident Reparations Act sug. gested a uniform automobile no-fault law with a $\$ 5,000$ floor for tort actions. UNIF. MOTOR VEHlCLE ACCIDENT REPARATIONS ACT $\S 5(a)(7)$ (1972). The model law simply mandates the reduction of any tort award by that amount. This approach to intangible injuries might both discourage nuisance suits and cause insurance companies to stop overcompensating minor injury claims.

164. "Unlike altruism-which is destroyed if purchased," muses Calabresi, "emotional pain, if converted into money terms, often is increased." G. CALABRESI, supra note 19, at 77. A similar argnment may be stated for physical pain as well.

165. Bell, supra note 8, at 373-74. The Association of Trial Lawyers of America offers guidelines for advising clients on how to maximize recovery for pain and suffering. See ANATOMY of A Personal Injury Law Surt: A Handbook of Basic Trial Advocacy 20-21 (R. Dudnik ed. 1968) ("Instructions to Clients" that include, for example, a suggestion that the victim keep a daily diary memorializing his suffering and disability).

166. The plaintiff suffering from emotional distress may be most injured by having to recall repeatedly the traumatizing event. 
stress and relive the gravity of his symptoms during pre-trial discovery and, possibly, trial itself. ${ }^{167}$ At least one study indicates that suffering is extended for those accident victims receiving or hoping to receive compensation. ${ }^{168}$

However, the secondary cost avoidance implications of intangible injury litigation are not all negative. Bringing suit may have therapeutic aspects. It may give the depressed plaintiff a sense of control over his life and the satisfaction of being able to confront his injurer. Moreover, the possibility of compensation may encourage him to seek professional help $^{169}$ and ease the financial concerns associated with his disabihities. An effective remedy system for intangible injuries, therefore, should accentuate the positive and minimize the negative ramifications of litigation.

In addition to the impact of hitigation, consideration should be given to social influences when evaluating the benefit to victins of a system awarding dainages for intangible injuries. By awarding damages for emotional and physical distress, society is formally recognizing such injuries. This recognition, in turn, may subtly enhance the perception of those affected by these injuries. Irrespective of fraud, there are items of damages which if recognized will increase and if demed will decrease. In a similar vein, societal reaction to the abohtion of a cause of action for alienation of affections as well as the recognition of a right to choose to abort a fetus illustrate the extent to which law both responds to and molds social attitudes. Both legal developments were responses to societal and cultural shifts. But both also led to greater societal acceptance of behavior ${ }^{170}$ and injury previously found offensive. ${ }^{171}$ Were the legal system to deny recovery for physical and mental distress, the level of suffering perceived by individuals likewise might decrease in response to this

167. Contested litigation itself is anxiety producing, both because of its delay and uncertainty and because the defendant usually attempts to discredit the plaintiff.

168. The study revealed that persons with surgically treated and those with nonsurgically treated low back pain both tended to be disabled longer or rehabilitated less successfully if they were receiving or hoping to receive compensation than if they were in no position to be compensated. Finneson, Modulating Effect of Secondary Gain on the Low Back Pain Syndrome, in 1 ADVANCES IN Pain Research and Therapy 949, 950-51 (J.J. Bonica and D. Albe-Fessard eds. 1976).

169. See supra text accompanying notes 50-51.

170. The most significant impact of Roe v. Wade, 410 U.S. 113 (1973), holding that women have a constitutional right to abort a pregnancy, may be this very symbolic ramification. Prior to Roe, a woman could obtain an abortion if she were financially able to travel to a state with liberal abortion laws. Given that Roe has been interpreted not to require public financing of abortions, Harris v. McRae, 448 U.S. 297 (1980); Maher v. Roe, 432 U.S. 464 (1977), a poor woman may still be unable to obtain an abortion. Thus, the women most affected by Roe are those who likely could have obtained an abortion even before the decision. The difference is that, following Roe, a decision to abort now may be seen as an exercise of a constitutional right and, therefore, less objectionable.

171. As will soon be evident, I am, however, not suggesting that increased callousness is necessarily a good thing, but only that it may result from such a symbolic change in the law. See infra text accompanying notes 172-74. 
reduction in societal support. An argument, therefore, can be made that placing the burden for physical and emotional distress on those who suffer may reduce the impact of such injuries and advance secondary cost avoidance goals.

Legal limitations on damages for intangible injury, in fact, might help to raise the pain threshold of mdividuals and make them more callous to environmental impacts. ${ }^{172}$ Our legal structure may very well encourage the development of a certain type of societal personality. However, before adoptimg such a proposal, we inust determine whether we wish to become more hardened, callous, and accustoined to trauma or whether we prefer to maintain a society which views some behavior as shocking and offensive, and some distress-whether emotional or physical-as worthy of concern. In essence, we must decide whether the long term costs of desensitizing our society are worth the short term gains of decreasing the secondary costs of intangible injuries. ${ }^{173}$ Especially with emotional distress, we may be willing to pay the price for a more caring and empathetic society. ${ }^{174}$

Again, however, the choice is not full hability versus none at all. As is true for primary cost avoidance, the best technique for secondary cost avoidance is one that contours its remedy to meet societal goals. A systein that awards damages for the pecuniary losses associated with intangible injuries_-but refuses general damages_-would demonstrate societal concern for the victim's plight while emphasizing rehabilitative needs rather than suffering. Thus, the systein's focus would be positive-on healing-rather than negative-on disability.

\section{Tertiary Cost Avoidance Under the Proposed System}

Obviously, no proposed compensation system for intangible injuries should be adopted unless its potential benefits outweigh its costs of impleinentation. It is to this consideration that this Section now turns. First, however, it would be helpful to review the basic aspects of this Article's proposal.

172. Some scholars, accepting this argument, insist that tort law should reject liability for emotional distress generally. See, e.g., Magruder, supra note 78, at 1035 ("Against a large part of the frictions and irritations and clashing of temperaments incident to participation in a community life, a certain toughening of the mental hide is a better protection than the law could ever be.")

173. The choosing of the immediate benefit without sufficient consideration of the long-term ramifications has been dubbed the "Faust attitude." G. Calanres1, supra note 38, at 57.

174. For example, there is presently considerable debate about the extent to which violence in children's television has desensitized young viewers to the need to avoid injury to others. See R.A. Baron, Human Aggression 101-11 (1977); 1 \& 2 National INST. OF MENTAL Health, TeleVISION AND BeHAVIOR: TEN Years of ScIENTIFIC Progress and IMPLiCations for the Eighties (1982); Buvinic \& Berkowitz, Delayed Effects of Practiced Versus Unpracticed Responses After Observation of Movie Violence, 12 J. EXPERIMENTAL SOC. PSYCHOLOGY 283 (1976). 


\section{a. The Proposal Summarized}

Just compensation and appropriate cost-allocation interests require that courts impose liability on defendants whose behavior foreseeably has resulted in intangible injuries to others. However, damages should be limited to the extent that these injuries have caused or are anticipated to cause transferable, out-of-pocket expenses. Such pecuniary damages are likely limited and capable of relatively firm proof. They, consequently, are less subject to plaintiff fabrication and jury abuse. Plaintiffs, under such a system, would feel vimdicated by public recognition that the defendant had unlawfully transgressed their physical and emotional security. Additionally, plaintiffs would be financially protected against economic dislocation caused by their injury or by efforts to aineliorate its effects. Moreover, such compensation would reduce the danger of intensifying the injury experienced because damage awards-and the tort process more generally-would focus on the plaintiff's positive efforts to rehabilitate and cope.

General damages serve less to compensate than to punish or deter. Consequently, nontransferable damages should be awarded only when the purpose is to pumish the morally blameworthy or encourage primary cost avoidance. As such, general damages should be available only when restitutive justice and deterrence are both feasible and desirable. Therefore, as the defendant's behavior becomes more calculated, general damages become mcreasingly justified. Consistent with this purpose, intentional wrongdoers should not be allowed to easily transfer the financial impact of their hability through insurance mechanisms. ${ }^{175}$ Instead, insurance companies should be permitted either to sue the willful wrongdoer for imdemnification or to collect significant surcharges from him for future coverage.

The proposed system would differ from the present tort process in a number of respects. Pain and suffering and emotional distress would be treated similarly. ${ }^{176}$ In general, damages would be more limited for both pain and suffering and entotional distress than under the present system. However, liability for emotional distress would be expanded to mclude cases where currently liability is not generally recognized. ${ }^{177}$ In essense, the proposed system shifts the tort process' focus from liability to remedy by expanding the universe of injured parties who may be compensated but limiting the ainount of dainages recoverable. Havmg undertaken this

175. Insurance policies inust cover even intentional wrongdoing. Otherwise intentionally victimized plaintiffs may find themselves unable to collect on their judgments from financially limited wrongdoers. See supra text following note 92.

176. Much of the criticism advanced against the present tort systein's handling of emotional distress is focused on its inconsistent treatınent of these damages. See supra note 11.

177. See infra text accompanying notes 194-227. 
basic review, the remainder of this Section explores the tertiary cost avoidance implications of the proposed system.

\section{b. Tertiary Cost Avoidance Implications}

$i$. Reduction of damages for pain and suffering and emotional distress. The substantial elimination of general damages for intangible injuries may impair the financial ability of injured parties to sue and the willingness of imsurance companies to settle claims fairly. ${ }^{178}$ Both of these dangers must be addressed.

(a) Litigation costs. Due to the substantial cost of litigation, accident victims, often already suffering from the economic impact of their mjuries, may not have sufficient funds to initiate and actively litigate their claims. Under the present system, such parties may be able to pursue legal remedies by entering into a contingent-fee contract with their attorneys. Under this contract, attorneys accept cases without compensation, contimgent upon an agreement that, should plaintiff win, the attorney will retain a portion, generally one-third to one-half, of the damages received. ${ }^{179}$

Widespread use of contingent-fee arrangements, however, may adversely affect plaintiffs under a tort system that denies general damages for imtangible injuries. Juries, generally aware of such arrangements, often mcrease damage awards to ensure that the plaintiff is compensated for both his loss and his attorney's fees. ${ }^{180}$ Because juries cannot easily increase the award for injuries of a provable and calculable nature, they

178. Such change may also foster windfall profits for these insurance companies. Insurance companies currently set premiums based on the risk of liability including general damages. Reforming the tort system to restrict general damages to a small number of cases would allow these companies to reap a short-term windfall. Consequently, sufficient time must be allowed to pass prior to the implementation of the proposed system for insurance premiums to adjust accordingly.

Although common law courts occasionally have postponed the impact of changes in doctrine so as to allow hability insurance plans to conform to the proposed changes, see, e.g., Spanel v. Mounds View School Dist., No. 621, 264 Minn. 279, 118 N.W.2d 795 (1962) (overruling judicially created sovereign imimunity, but postponing effectiveness until close of legislature's next session), legislative rather than judicial institutions are better equipped to make the changes proposed in this Article. Legislatures often change policy and then postpone implementation so as to allow commercial practices to conform through market pressures. This Article's proposal may be more readily accepted by the populace if it arises as a legislative reform. This is because it would have the benefit of being considered in its entirety, rather than through a case-by-case consideration of equities. Properly drafted legislation, thus, could avoid both the appearance and actuality of insurance company windfalls.

179. For analysis of this contingent-fee system, see generally F. MACK1NNON, CONTINGENT Fees for Legal Services (1964); Arlidge, Contingent Fees, 6 OTTAWA L. Rev. 374 (1974); Combs, The Contingent Fee Contract, 28 TEX. B.J. 949 (1965); Schwartz \& Mitchell, An Economic Analysis of the Contingent Fee in Personal-Injury Litigation, 22 STAN. L. REV. 1125 (1970).

180. For example, a jury, concluding that a plaintiff deserves to be compensated for injuries resulting in $\$ 300,000$ worth of damages, may be concerned that due to contingent fees the plaintiff will actnally receive only two-thirds of any award for his injuries. In such a case the jury might award $\$ 450,000$ in damages to assure full plaintiff compensation. 
tend to provide for attorney costs by increasing general damages for intangible injuries. ${ }^{181}$ However, to permit contingent-fee arrangements in a tort system that eliminates general damages would require that the attorney's share come from damages needed to compensate the plaintiff for pecuniary loss. Consequently, any process that rejects such general damages must examine the reluctance of American jurisprudence to grant attorney fees.

If, in fact, general damages for intangible injuries constitute the source of attorney fees in the present system, it seems a peculiarly clumsy substitute for a system of court-awarded legal expenses. However, American courts traditionally have refused to award attorney fees in tort litigation, reasoning that settlements otherwise would be influenced more by concerns of litigation costs than by the merits of individual cases. ${ }^{182}$ Ultimately, lowever, a contingent-fee system may have this same effect. Litigation costs, whetller court-awarded or disguised as general damages, tend to influence settlement considerations. The systems differ only in that inflated general damage awards accomphish this result less overtly and, thus, with less impact on the symbols of our adversary process. ${ }^{183}$ This questionable advantage of the contingent-fee system would not seem to justify its potential adverse impact on plaintiff recovery.

However, a second, more cogent argument for contingent fees has been made. Under a court-awarded fee system, fees only are awarded to successful parties and then only for reasonable fees earned in the particular case. But estimates of hitigation costs and determinations of whether to bring suit are made prior to research or discovery, when neither the plaintiff nor his attorney can be assured of ultimate victory. Consequently, it is argued, a system of court-awarded fees forces plaintiffs to accept the risk that a case will prove unsuccessful and they will have to absorb their own attorney costs. This risk may be more than plaintiffs of limited means can bear. As a result, many suits which, if properly pursued, would have proven successful might not be brought. Poorer accident victims therefore could be deprived of deserved compensation. On the other hand, a contingent-fee system compensates lawyers not only for time spent on winning cases but also for time expended on losing causes. Winning plaintiffs, in effect, contribute to a pool that funds attorney fees for all personal injury cases. Successful plaintiffs are subsidizing those plaintiffs whose actions prove nnsuccessful.

The proposition that contingent fees help finance suits by the poor is

181. See Morris, supra note 36, at 477.

182. See, e.g., D. DoBns, HANDBOOK ON THE LAw OF Remed1es $\S 3.8$, at 201-02 (1973).

183. For other examples of mechanisms by which law masks the effect of its decisions, see Ingber, The Interface of Myth and Practice in Law, 34 VAND. L. REv. 309, $332-38$ (1981) [hereinafter cited as Ingber, Interface]. See generally Ingber, Procedure, Ceremony and Rhetoric: The Minimization of Ideological Confict in Deviance Control, 56 B.U.L. REv. 266 (1976). 
founded more on theory than practice. The argument assumes that attorneys often accept cases with a high risk of no financial return. But as Professor Jeffrey O'Connell has persuasively argued, ${ }^{184}$ this assumption is unfounded. Lawyers rarely accept cases on a contigent-fee basis that do not eventually result in recovery. In fact, one study undertaken in New York City indicated that payments were made in ninety percent of the cases undertaken. ${ }^{185}$ It is therefore questionable whether the contingent-fee system really helps poor tort victims obtain legal representation when their claims are relatively uncertain or involve limited damages.

Since virtually all suits currently initiated have some settlement value, the risk is small that plaintiffs currently able to find representation would fail to do so in a system of court-awarded attorney fees. ${ }^{186}$ Such a system actually may make it economically worthwhile for attorneys to take on small but complicated cases. Small, risky cases may be vital to poor individuals, ${ }^{187}$ yet they are precisely those that are least attractive under a contingent-fee arrangement. Attorneys, assured of a reasonable fee if victorious, may remain interested in cases involving limited damages. ${ }^{188}$

For these reasons, the proposed abohition of general damages for pain and suffering and emotional distress in all but willful torts is desirable only if courts will grant attorney fees to successful litigants. A systein of court-awarded attorney fees, in fact, may be necessary to avoid a charge that the elimination of general damages for intangible injuries results in an unconstitutional deprivation of an accident victim's due pro-

184. J. O'CONNELL, THE INJURY INDUSTRY AND THE REMEDY OF NO-FAULT INSURANCE 49 (1971).

185. Id.

186. Some suits, it is argued, have little settlement potential because their sueeess would require sophistieated and creative arguments by counsel resulting in legal change. Acceptance of sueh cases would be too risky except on a contingent-fee basis. But practice in federal civil rights cases where attorney fees are granted for successful plaintiffs, 42 U.S.C. $§ 1988$ (1982), suggests otherwise. Since courts may consider the trailblazing nature of the litigation in determining what fee is reasonable, Blum v. Stenson, 104 S. Ct. 1541, 1548-50 (1984), creative arguments are sufficiently eneouraged. See also id. at 1550-51 (Brennan, J., concurring).

187. The poor individual, for example, may face pecuniary losses which, although small, are beyond his economic means. The present system, which does not take aceount of such eircumstances, may make an injured party feel that the system is imdifferent to his plight, thus causing him additional emotional distress.

188. At first glanee, such encouragement to litigate small claims may seem to foster nuisance suits. It is proper, however, to internalize small as well as large accident costs into the activity that generated them. The concern about nuisance suits stems from the possibility of legitimate costs being illegitimately infiated. The proposed system avoids this problem by awarding damages only for pecumary losses. In addition, an attorney who spends excessive time on a simple case will not be compensated beyond his reasonable attorney fees. Incentives to settle also may reduce the tertiary costs of multiple small-claim litigation. 
cess rights. ${ }^{189}$ There is still the danger, however, that the proposed reduction of damages will remove an incentive for insurance coinpanies to settle clainis fairly.

(b) Settlement incentives. The proposed abolition of general damages for intangible injuries could imfluence the settlement process. Some fear that insurance companies-no longer faced with the uncertamty of such damages nor the risk of unfettered, plamtiff-predisposed juriesmay lack incentives to make or accept settlement offers. ${ }^{190}$ In many cases where hability is clear this fear is less justified. In such cases, settlements are likely to increase under the proposed system because the residual damage issue is more subject to objective proof and is less subject to factfinder discretion at trial. Except where plaintiffs require immediate comipensation, ${ }^{191}$ they need not accept a settlement offer for less than their pecuniary loss. Thus, insurance compamies will feel pressure to settle such claims to avoid paying plaintiff attorney fees in addition to a certam verdict.

However, there is a real danger of discouraging fair settlenients when liability is unclear or when the plaintiff's compensation needs are pressing. An insurer, facing no threat of a judgment beyond the victim's pecuniary loss, niay refuse to pay total pecuinary loss. The insurer may argue that when hability is uncertain, it is justifiable to discount the damages by the probability of success. ${ }^{192}$ Similarly, the insurer may coerce a victim to accept a discount by emphasizing the long delays inherent in the litigation process.

Although discounting is arguably appropriate when liability is trnly uncertain, compensatimg plaintiffs for less than pecuniary loss is disquieting. To encourage insurers to accept viable settlenient offers, a defendant should be required to pay the plaintiff a fixed surcharge above the awarded damages if the defendant had previously rejected a settlement offer equal to or less than the judgment rendered at trial. ${ }^{193}$ Such a rule

189. See generally O'Connell, supra note 31 .

190. Id. at 358-59.

191. Such may be the plight of the most severely injured who are, consequently, most likely to be influenced by fear of compensation delays.

192. Under the present system where general damages for intangible injuries are possible, insurance companies are often inclined to settle uncertain claims by agreeing to pay at least pecuniary losses. See H.L. Ross, Settled Out of Court: The Social Process of Insurance Claims ADJUSTMENT 230 (1970). The insurer thus avoids the risk of general damages and the planitiff is protected from financial dislocation.

193. Determining the size of this surcharge may, however, prove difficult. If too small, the incentive to settle may be inadequate. If too large, there may be an overincentive to settle. It is unlikely that this latter danger will encourage nuisance suits, however, because damages under iny proposal are limited to pecuniary losses, which are more readily provable, discoverable, and predictable. This systen, especially when combined with conservatorships, see supra text preceeding note 52 , also decreases any incentive for plaintiffs to inflate settlement deinands. 
would reinove any incentive to reject reasonable settleinent offers caused by the ehimination of general dainages.

ii. Expansion of liability for emotional distress. The proposed system for compensation of intangible injuries, while limiting damages, also broadens the scope of liability for emotional distress beyond the present norm. Although courts during the last twenty-five years have expanded significantly the circumstances in which they will award damages for emotional distress, ${ }^{194}$ historically courts have regarded such injuries with great discomfort ${ }^{195}$ and have awarded damages only grudgingly. ${ }^{196}$

Judicial and scholarly concerns over granting damages for emotional distress have focused on practical problems. Foremost of these concerns has been the behief that emotional distress claims are easily feigned and exaggerated. ${ }^{197}$ In addition, courts have been uncomfortable tracing the causal connection between the defendant's behavior and plaintiff's emotional condition. ${ }^{198}$ Finally, they have worried that the recognition of such dainages would open the floodgates of litigation, giving rise to liability grossly disproportionate to wrongdoing. ${ }^{199}$

In response to these concerns, courts have dcveloped several legal tests either to assure the genuineness of the clained injury ${ }^{200}$ or to limit the scope of liability. ${ }^{201}$ Initially, inost jurisdictions required a concurrent physical injury or condition. ${ }^{202}$ Many courts also insisted on proof

194. See, e.g., Keck v. Jackson, 122 Ariz. 114, 593 P.2d 668 (1979); Dillon v. Legg, 68 Cal. 2d 728, 441 P.2d 912, 69 Cal. Rptr. 72 (1968); Dziokonski v. Babinbeau, 375 Mass. 555, 380 N.E.2d 1295 (1978); Battalla v. State, 10 N.Y.2d 237, 176 N.E.2d 729, 219 N.Y.S.2d 34 (1961); Whetham v. Bismarck Hosp., 197 N.W.2d 678 (N.D. 1972); D'Ambra v. United States, 114 R.I. 643, 338 A.2d 524 (1975).

195. Courts regarded emotional distress as something "'metaphysical,' 'too subtle and speculative to be capable of admeasurement by any standard known to the law.'" W. Prosser, supra note $1, \S 12$, at 50 .

196. Most cases involving claims for emotional distress fall within a limited number of categories. They include situations where plaintiff witnesses or learns of danger or harm to somc third party (commonly referred to as "bystander liability" cases), is confronted by or escapes from some physical danger, is forced to endure personal indignities, or is offered and nearly eats impurc foods.

197. Brody, supra note 54, at 259; Rosenberg, supra note 23, at 878 n.111; Teff, supra note 48, at 101.

198. Brody, supra note 54 , at 259 . Some courts feared that the plaintiffs condition or some susceptibility to that condition might have existed prior to the defendant's conduct, or that the plaintif's consciousness might constitute an intervening cause.

199. W. Prosser, supra note $1, \S 4$, at 21; Brody, supra note 54, at 259-60; Teff, supra note 48, at 101. The argument of disproportionate liability is not convincing when the defendant acts willfully. See supra note 92 and accompanying text.

200. Prosser, supra note 78, at 43; see also Molien v. Kaiser Found. Hosps., 27 Cal. 3d 916, 930, 616 P.2d 813, 821, 167 Cal. Rptr. 831, 839 (1980).

201. For a full discussion of these various tests, see Brody, supra note 54, at 233-41.

202. International Ocean Tel. Co. v. Saunders, 32 Fla. 434, 439-40, 14 So. 148, 149 (1893); Sullivan v. H.P. Hood \& Sons, 341 Mass. 216, 221-22, 168 N.E.2d 80, 84-85 (1960); see also RESTATEMENT (SECOND) OF TORTS $§ 436$ A (1965); Teff, supra note 48, at 105; Notc, The Death of the Ensuing Physical Injury Rule: Validating Claims for Negligent Infliction of Emotional Harm, 10 HOFSTRA L. REV. 213, 214-15 (1981). In essence, damages for emotional distress were parasitic to 
of an external blow or some form of "impact."203 More recently, courts have developed a "zone-of-danger" test. Under this test, plaintiffs may collect for emotional distress only if they are withm the zone physically endangered by the defendant's tortious conduct. This test does not require physical injury, and the plamtiffs' distress may result either from fear for their own safety or from witnessing injury to others. ${ }^{204}$ Those within this zone are foreseeable victims to whom the defendant thus owes a duty of reasonable care. ${ }^{205}$

The most dramatic contemporary expansion of liability for emotional distress was ushered in by the California Supreme Court's opinion in Dillon v. Legg. ${ }^{206}$ Although not within the zone of danger, the plaintiff recovered damages for emotional imjuries resulting from witnessimg the negligently caused death of her daughter. In attempting to formulate a method to test for liability in such circumstances, the court articulated several guidelines. It instructed courts to consider how close the plaintiff was to the scene of the accident, whether the plaintiff directly observed the accident, and whether the plaintiff and the victim were closely related. ${ }^{207}$

The courts have developed these various tests to limit the perceived dangers of recognizing liability for all damages of reasonably foreseeable victims. ${ }^{208}$ Each of these judicially imposed tests, however, also is blatantly arbitrary. ${ }^{209}$ A slight physical injury does not assure the genuineness of an emotional distress claim or guarantee that awards for the

damages for physical injuries. The physical injury apparently assured the genuineness of the claim and reduced the number of possible suits.

203. W. Prosser, supra note 1, §54, at 331; see also Easton v. United Trade School Contracting Co., 173 Cal. 199, 202-03, 159 P. 597, 599 (1916); Gillam v. Stewart, 291 So. 2d 593 (Fla. 1974), overruled by Champion v. Gray, No. 62,830 (Fla. Mar. 7, 1985); Spade v. Lynn \& B.R.R., 168 Mass. 285, 290, 47 N.E. 88, 89 (1897), overruled by Dzionkonski v. Babincau, 375 Mass. 555, 380 N.E.2d 1295 (1978); Mitchell v. Rochester Ry., 151 N.Y. 107, 45 N.E. 354 (1896), overruled by Battalla v. State, 10 N.Y.2d 237, 176 N.E.2d 729, 219 N.Y.S.2d 34 (1961).

204. E.g., Maryland v. Thomas, 173 F. Supp. 568 (D. Md. 1959); Waube v. Warrington, 216 Wis. 603, 608, 258 N.W. 497, 499 (1935); see also RESTATEMENT (SECOND) OF TORTS §§ 313(2), 436(3) (1965); Comment, Bystander Recovery for Negligent Infliction of Emotional Distress in Iowa: Implementing an Optimal Balance, 67 IowA L. REV. 333, 338 (1982); Comment, Duty, Foreseeability, and the Negligent Infliction of Mental Distress, 33 ME. L. REv. 303, 305 (1981).

205. The zone-of-danger test is an obvious outgrowth of Justice (then Judge) Cardozo's landmark opinion in Palsgraf v. Long Island R.R., 248 N.Y. 339, 162 N.E. 99 (1928).

206. 68 Cal. 2d 728, 441 P.2d 912, 69 Cal. Rptr. 72 (1968).

207. Id. at $740-41,441$ P.2d at 920,69 Cal. Rptr. at 80 .

208. There would be no need for special rules limiting liability for einotioual distress if the victim was an unduly sensitive individual unexpectedly reacting to injury of a third party. General principles of tort law would deny hability in such cases. These special rules do serve, however, to limit liability in the situations where general tort doctrine would grant hability. See Snnth v. Postal Tel. Cable Co., 174 Mass. 576, 577-78, 55 N.E. 380 (1899) (Holmes, C.J.) ("[The impact rule] is not put as a logical deduction from the general principles of liability in tort, but as a limitatiou of those principles upon purely practical grounds.").

209. W. Prosser, supra note $1, \S 54$, at 335. See generally Pearsou, supra note 8. 
"mental anguish" will be proportional to the wrongdoing. ${ }^{210}$ On the other hand, lack of physical injury alone is not a reliable indication of a fraudulent claim. ${ }^{211}$ Moreover, the presence of a minor "impact" 212 makes emotional distress no easier to prove (or disprove) or quantify. Yet under that rule, once '[t]he magic formula 'impact' is pronounced[,] the door opens to the full joy of a complete recovery."213 The zone-ofdanger rule is similarly arbitrary; it is based on the absurd proposition that a parent's emotional distress caused by the negligent death of his or her child is not foreseeable. ${ }^{214}$ Even the Dillon guidelines have generated arbitrary and inflexible duty limitations to recovery for emotional distress. For example, parents who did not actually observe the event that caused their child's mjury have been denied damages. ${ }^{215}$ Liability for

210. See, e.g., Draper v. Baker, 61 Wis. 450, 21 N.W. 527 (1884) (\$1,200 for spitting in the face); Craker v. Chicago N.W. R. Co., 36 Wis. 657 (1875) (school teacher who was kissed awarded $\$ 1000$ for her "terror and anguish, her outraged feeling and insulted virtue, her inental humiliation and suffering"); Ragsdale v. Ezell, 49 S.W. 775 (1899) (\$700 against defendant who "seized hold of [plaintiff] and put his arms around her, and . . . hugged and kissed her . . . until she pulled away from him and ran into another room and locked the door"); see also Magruder, supra note 78, at 1034.

211. See, e.g., Fournell v. Usher Pest Control Co., 208 Neb. 684, 305 N.W.2d 605 (1981) (Plaintiff, hospitalized three times for reactive depression and treated by a psychiatrist constantly for morc than two years, denied recovery because no physical injury.).

212. "Impact" has meant a slight blow, Homans v. Boston Elevated Ry. Co., 180 Mass. 456, 62 N.E. 737 (1902); a trifiing burn, Kentucky Traction Ternimal Co. v. Roman's Guardian, $232 \mathrm{Ky}$. 285, 23 S.W.2d 272 (1929); an electric shock, Clark v. Choctawhatchee Elec. Coop., 107 So. 2d 609 (Fla. 1958); a jolt or jar, Zelinsky v. Chimics, 196 Pa. Super. 312, 175 A.2d 351 (1961); a forcible seating on the floor, Driscoll v. Gaffey, 207 Mass. 102, 92 N.E. 1010 (1910); dust in the eye, Porter v. Delaware, L. \& W.R. Co., 73 N.J.L. 405, 63 A. 860 (1906); or the inhalation of smoke, Morton v. Stack, 122 Ohio St. 115, 170 N.E. 869 (1930). The requirement has even been satisfied by a fall brought about by a faint after a collision, Comstock v. Wilson, 257 N.Y. 231, 177 N.E. 431 (1931), or the plaintiff's wrenching of her own shoulder in reaction to the fright, Freedman v. Eastcrn Mass. St. Ry., 299 Mass. 246, 12 N.E.2d 739 (1938). A Georgia circus case, Christy Bros. Circus v. Turnage, $38 \mathrm{Ga}$. App. 581, 144 S.E. 680 (1928), found "impact" where the defendant's horse "cvacuated his bowels" into the plaintiff's lap.

213. Goodrich, Emotional Disturbance as Legal Damage, 20 M1CH. L. REv. 497, 504 (1922).

214. For example in King v. Phillips, [1953] 1 Q.B. 429, a mother heard screams, looked out a window and saw her son's tricycle under a taxi. In denying liability for the mother's emotional distress Lord Denning asserted that "[t] he taxicab driver cannot reasonably be expected to have foreseen that his backing [his eab over a young child] would terrify a mother 70 yards away. . . ." Id. at 442 (Denning, L.J., concurring). If the driver could be said to have forescen killing a young child it is no great leap of faith to believe that he ought also to have anticipated that the child's parents would be distraught. The Court is merely arbitrarily limiting the extent of the driver's hability. See W. Prosser, supra note $1, \S 54$, at 335 .

215. California courts have demed recovery under Dillon to plaintiffs who were not present at the scene to witness the accident. Recovery was denied a mother, for example, who arrived on tlie scene of an automobile accident involving her son about three minutes after its occurrence. Arauz $\mathrm{v}$. Gerhardt, $68 \mathrm{Cal}$. App. 3d 937, $137 \mathrm{Cal}$. Rptr. 619 (1977). The court ruled the plaintiff was "not near enough to the scene to have any sensory perception of the impact," and observed that impressions were not "caused by the direct emotional impact of her sensory and contemporaneous observance of the accident." Id. at 949, 137 Cal. Rptr. at 627 (quoting Dillon, 68 Cal. 2d at 740, 441 P.2d at $920,69 \mathrm{Cal}$. Rptr. at 80 ). Similarly, a father who came upon a wrecked automobile containing his two daughters within a "few moments" of the accident could not recover under Dillon bccause 
emotional distress therefore may depend on which side of the street the plaintiff was standing and whether he was looking in the right direction at the instant of the accident.

Although the rules limiting liability are arbitrary, the concerns against which they are directed are not wholly unfounded. Those who support full liability for emotional distress insist that medical science and psychology have become sufficiently refined ${ }^{216}$ that the judicial process may be relied on to dismiss fraudulent claims and properly determine causal links. ${ }^{217}$ To deny all legitimate claims of emotional distress in order to screen out fictitious or exaggerated ones clearly is unjust. ${ }^{218}$ Nevertheless, to ignore that intangible injuries pose significant risks of plaintiff abuse and jury error is patently unrealistic. ${ }^{219}$

The primary reason for limiting hability for emotional distress is the danger of opeming the courts to an "infinity of actions."220 Every accident victim is likely to have family and friends. Without limiting liability, so it is theorized, eacli act of negligence may lead to multiple claims that could crush the defendant with liability disproportionate to his wrongdoing. ${ }^{221}$ Professor Fleming James has likened sucli arguments to "the fabled cry of 'wolf,' " notimg that such fears often have been invoked only to later be proven groundless. ${ }^{222}$ Nevertheless, even James cautions that "[t]he caveats . . . do not all run in one direction. As the fable itself suggests, although the cry of 'wolf' may often be false, there are wolves,

according to the "uncontradicted facts there has been no showing that [the plaintiff] saw, heard, or otherwise sensorily perceived the injury-producing event." Parsons v. Superior Court, $81 \mathrm{Cal}$. App. 3d 506, 512, 146 Cal. Rptr. 495, 498 (1978). In Hathaway v. Superior Court, 112 Cal. App. 3d 728, 169 Cal. Rptr. 435 (1980), the parents of a child electrocuted because of the defendant's alleged negligence could not recover because they did not see the electrocution take place, although the accident occurred outside the house occupied by the plaintiffs, and they saw their son in his death throes ininutes later. Id. at 736, $169 \mathrm{Cal}$. Rptr. at 440.

216. See Comment, Negligently Inficted Mental Distress: The Case for an Independent Tort, 59 GEO. L.J. 1237, 1248-53, 1258-62 (1971). The Comment exammes the medical aspects of mental reactions to trauma and concludes that "medical science is capable of satisfactorily establishing the existence, seriousness, and raunifications of emotional harm." Id. at 1253.

217. Dillon v. Legg, 68 Cal. 2d 728, 737, 441 P.2d 912, 918, 69 Cal. Rptr. 72, 78 (1962) ("Courts must depend upon the efficacy of the judicial processes to ferret out the meritorious from the fraudulent in particular cases."); Einden v. Vitz, 88 Cal. App. 2d 313, 319, 198 P.2d 696, 700 (1948).

218. Orlo v. Connecticut Co., 128 Conn. 231, 239, 21 A.2d 402, 405 (1941); Owens v. Liverpool Corp., [1939] 1 K.B. 394, 400 (1938).

219. These risks often are as high for claims of pain and suffering as for claims of emotional distress. C. MCCoRMick, supra note 12, at 322.

220. W. Prosser. supra note 1, $\S 4$, at 21 (quoting Winterbottom v. Wright, 152 Eng. Rep. 402 (Ex. 1842)).

221. A similar fear was long used as justification for the requirement of "privity of contract" in product liability cases. Winterbottoin v. Wright, 152 Eng. Rep. 402 (Ex. 1842).

222. James, Limitations on Liability for Economic Loss Caused by Negligence: A Pragmatic Appraisal, 25 VAND. L. REv. 43, 48 (1972). 
and wolves are dangerous."223 Consequently, courts have been haunted by the spectre of unlimited liability for emotional distress crushing the defendant because of a momentary lapse of proper care. ${ }^{224}$

Although these fears at times may be valid, judicially developed rules meant to confront them are defective because they concentrate upon the wrong issue: the scope of liability for emotional distress rather than the type and extent of damages. ${ }^{225}$ As discussed, the pressures on the tort system to expand such liability arise primarily from an understandable empathy toward the sufferer, a concern for the impact of his suffering and a need to symbolically express that concern. The proposal presented in this Section, which separates the issue of liability from damages and then recognizes the claims for compensation for specific/pecumary losses suffered by all foreseeable victims, adequately responds to these pressures. Moreover, the reforins proposed also would lessen mcentives for fraudulent claims and reduce the danger of overburdening the defendant. ${ }^{226}$

Although the proposed system cannot completely elminate the danger of error in determining causation, a complete denial of liability in uncertain cases would also create a risk of error. Where difficulties in determining causation arise from informational limitations rather than plaintiff fraud, the risk of assignimg too much or too little liability is inevitable. Under the proposed system, at least, the defendant's behavior will lead to liability only if it was reasonably hkely to cause significant distress in the ordinary individual. Additionally, the current state of medical and psychiatric expertise hopefully will reduce the likelihood of error.

223. Id. at 49.

224. As a consequence of similar concerns, courts have refrained from holding accountants responsible when their negligent evaluation of the books of their client leads to third-party injuries. E.g., Ultramares Corp. v. Touche, 255 N.Y. 170, 174 N.E. 441 (1931). Each enterprise other than the accountant's client injured by reliance on the accountant's work is required to absorb its own loss. Injured third parties thus cannot place the sum of their losses on the backs of the defendants. The analogy to third-party suits for emotional distress caused by negligent accidents is readily apparent.

Of course differences also are apparent. When the third-party enterprise internalizes losses caused by accoimtant error, that type of error merely becomes another risk of doing business. Enterprises may avoid this risk by demanding independent verification of the accountant's report or pass it on to enterprise beneficiaries as a decrease in profit or an increase in consumer prices. Wlien the third-party individual who suffers emotional distress following a negligent accident absorbs the cost of his injuries, lie may only avoid them by becoming callous, supra text accompanying notes 172-74, and he may not be able to pass them on to others at all, supra text accompanying notes 36-38.

225. Justice Thurgood Marshall, when analyzing the dangers of defamation suits (another intangible injury), first recognized that the crucial issue was the size of judgments rather than the existence of liability per se. Rosenblooin v. Metroinedia, Inc., 403 U.S. 29, 82 (1971) (Marshall, J., dissenting).

226. Needless to say, dangers of excessive and disproportionate liability overburdening the defendant are of little significance when the tortfeasor willfully caused the emotional distress. See W. Prosser, supra note $1, \S 54$, at 329 . In such circumstances, general damages and all their consequences are justified. 
In any event, primary cost avoidance interests suggest that it is preferable to err on the side of too much liability. ${ }^{227}$

This Section advocates replacing strained and arbitrary rules that limit liability for emotional distress with a damage limitation model that would more effectively fulfill the objectives of tort law. Part I of this Article, in its treatment of pain and suffering and emotional distress, has used this focus on remedies to justify expanding liability wliile restricting damages. But tle intangible injuries of defamation and privacy invasions differ from those previously discussed. Rather than resultimg from accidents, these intangible injuries normally arise in situations where the plaintiff's interests clash with societal and individual values of free speech and press. Consequently, altliough the damage model developed in Part I may serve as a beneficial starting poimt, any proposal for compensating for these injuries must recognize their umique nature, understand the conflict of values they engender, and develop a remedy scheme for each that minimizes the negative implications of these conflicts. Part II will address these issues and refine the proposed reforıns for intangible imjuries to reflect these special interests.

\section{II}

\section{Defamation and Privacy: The Unique Problem of TORTS IMPLICATING THE FIRST AMENDMENT}

Defamation and privacy imjuries may be viewed as particular types of intangible injuries. ${ }^{228}$ The gravanen of a defamation action is the creation of a false opinion about a person, whether in the mind of one other person or many people, while the gravamen in the public disclosure privacy cases is the degrading of a person by exposing intimate aspects of his life to public view. In addition to compensating for emotional distress, damages for such injuries demonstrate social recognition of an interest in human dignity encapsulated by these reputational ${ }^{229}$ and privacy ${ }^{230}$ concerns.

227. This analysis is reminiscent of that used by the California Supreme Court in the landmark case of Summers v. Tice, 33 Cal. 2d 80, 199 P.2d 1 (1948). Plaintiff was injured by a shot from one of two negligent hunters. The court, refusing to require the plaintiff to prove which of the hunters had caused the injury, granted him a judgment against both. Apparently the court beheved it was better to burden both defendants when they each participated in conduct which risked precisely the injury that took place rather than to dismiss the case for lack of sufficient proof of causation and thereby burden the innocent victim.

228. See generally Probert, supra note 145.

229. An individual's right to the protection of his own good naine "reflects no more than our basic concept of the essential dignity and worth of every human being. . . ." Rosenblatt v. Baer, 383 U.S. 75, 92 (1966) (Stewart, J., concurring).

230. The specific importance of insulating a portion of one's life from the public eye was eloquently described by Edward Bloustein:

The man who is compelled to live every minute of his life among others and whose every need, thouglit, desire, fancy or gratification is subject to public scrutiny, has been deprived 
The torts of defamation and privacy invasion promote this dignity interest in several ways. First, an action for privacy invasion provides a public recognition of privacy rights by formally acknowledging their violation. An action for defamation, on the other hand, provides public vindication of reputational concerns by setting the record straight in a public forum. ${ }^{231}$ Second, a successful suit can publicly reprimand and economically penalize publishers of defamatory statements or intimate details of another's life. The risk of such suits presumably deters individuals from making statements that invade privacy or are falsely defamatory. Third, a successful suit supposedly compensates the victim for both the economic and personal loss caused by such statements.

\section{A. A Conflict of Values}

Defamation and invasions of privacy differ from other intangible mjuries because the threat they pose to dignitary interests arises out of communication efforts. To the extent that potentially damaging communication is restricted or financially burdened, reputation and privacy may be protected. However, communication is itself highly valued as part of our society's interest in "free expression."232

One may view the first amendment's focus on freedom of speech and press as an attempt to protect and encourage discussion essential to the process of reason. In fact, orthodox first amendment theory ${ }^{233}$ places freedom of expression at the pinnacle of political values. It asserts as a corollary to democratic theory that each person's ideas are equally worthy and that society benefits most from broad dissemination of different views. ${ }^{234}$ A major tenet of the orthodox theory, therefore, is that each citizen has a riglit to participate in governmental decisionmaking. ${ }^{235}$

of his imdividuality and human dignity. Such an individual merges with the mass. His opinions, being public, tend never to be different; his aspirations, being known, tend always to be conventionally accepted ones; his feelings, being openly exhibited, tend to lose their quality of urique personal warmth and to become the feelings of every man. Such a being, although sentient, is fungible; he is not an individual.

Bloustem, Privacy as an Aspect of Human Dignity: An Answer to Dean Prosser, 39 N.Y.U. L. REV. 962, 1003 (1964).

231. On the subjeet of vindication, see Rosenblatt v. Baer, 383 U.S. 75, 93 (1966) (Stewart, J., concurring); RESTATEMENT OF TORTS $\$ 569$ comment b (1938); Cohen, A New Niche for the Fault Principle: A Forthcoming Newsworthiness Privilege in Libel Cases?, 18 UCLA L. REv. 371, 375-77 (1970); Note, Vindication of the Reputation of a Public Official, 80 HARV. L. REv. 1730 (1967).

232. This interest in freedom of expression includes the freedoms of speech and press. See, e.g., T. EMERSON, THE SYSTEM OF FREedOM OF EXPRESSION 3 (1970).

233. For a description and critique of first amendinent orthodoxy, see Ingber, The Marketplace of Ideas: A Legitimizing Myth, 1984 DUKE L.J. 1.

234. This presumption closely parallels the ideals of the Jacksomian model of democracy. See L.R. LEWIS, DEMOCRACY AND THE LAW 199-201 (1963).

235. Rawls, Constitutional Liberty and the Concept of Justice, in 6 Nomos: JUSTICE 98 (1963). This view rejeets the elitist argument that only those possessing the expertise pertinent to any issue should be involved in decisions concerning that issue. Sec, e.g., B.F. SkINNER, WALDEN Two 55 
Free expression, it is argued, not only recognizes the equahity of all citizens, but also promotes informed decisionmaking by the electorate ${ }^{236}$ through the "discovery and spread of political truth." "237 This first amendment theory also views free expression as a mechanism that diverts protests for social change away from revolution and towards the creation of a popular consensus. ${ }^{238}$ Freedom of expression, in short, replaces the stratagem of force with that of reason.

These positive justifications for a value of free expression seek to demonstrate that first amendment activities are especially valuable and thus deserve special protection. But negative justifications for free speecl1 also are available. These justifications stress the special dangers of allowing governmental regulation of expression. For example, Professor Frederick Schauer insists:

Freedom of speech is based in large part on a distrust of the ability of government to make the necessary distimctions, a distrust of governmental determinations of truth and falsity, an appreciation of the fallibility of political leaders, and a somewhat deeper distrust of governmental power in a more general sense. ${ }^{239}$

This argument emphasizes the danger of authorizing goverument to determine what is valuable commumication. Fearful that government censors may be predisposed to prevent expression that questions government policy and authority, this perspective emphasizes the first amendment's role as a limit upon the ability of those with political power to regulate the content of expression. ${ }^{240}$

(1948). Inherent in the orthodox theory is a disavowal of any claim of infallibility in tlie judgment of trutll. Truth is viewed not as a fixed concept, but as transient and fleeting, e.g., Abrains v. United States, 250 U.S. 616, 630 (1919) (Holnies, J., dissenting).

236. Professor Alexander Meiklejohn considered the function of free expression for denocratic decisionniaking to be the preeminent function of the first amendnuent. A. MEIKLEJoHN, FreE SPEech AND ITS RELATION TO SELF-GOVERNMENT 22-27 (1948). lndeed, he viewed the first amendment as an absolute restriction on legislation intended to linit freedoin of speeeh. However, he thought tliat only speech pertinent to denocratic consideration fell within this absolution. See id. at 24-25. In later years, however, Meiklejohn found the distinction between public and private speech difficult to naintain. See generally Meiklejohn, The First Amendment Is an Absolute, 1961 SuP. Cr. REV. 245.

237. Whitney v. California, 274 U.S. 357, 375 (1927) (Brandeis, J., concurring); see also Bork, Neutral Principles and Some First Amendment Problems, 47 IND. L.J. 1, 24 (1971).

238. Justice Brandeis, in Whitney v. California, summarized the view that free expression reduces social strife.

Those wlio won our independence ... knew that order cannot be secured nierely through fear of punishment for its infraction; that it is hazardous to discourage thought, hope and iniagination; that fear breeds repression; that repression breeds hate; that hate menaces stable government; that the path of safety lies in the opportunity to discuss freely supposed grievances and proposed reniedies; and that the fitting remedy for evil counsels is good ones.

274 U.S. 357, 375 (1927) (Brandeis, J., concurring).

239. F. SCHAUER, FREE SPEECH: A PHILOSOPHICAL ENQUIRY 86 (1982).

240. Sinilarly, the first amendment inust also limit the ability of the general public to control expression. A systein of free expression is necessary to prevent the developnient of tyranny. In a 
Essentially, the first amendment forbids the governmental processes from regulating, burdening, or censoring expression according to some evaluative standard of the worth ${ }^{241}$ or social cost of its content. ${ }^{242}$ Yet the tort process involves precisely such an evaluative function. The torts of defamation and privacy invasion are founded upon a notion of decency that provides a standard by which acts, or more specifically, words may be judged. This use of an evaluative process poses a conflict between tort law and orthodox first amendment theory. The conflict emerges between the tort law value of decency and the first amendment value of reason. ${ }^{243}$ Any proposal for the protection of reputational or privacy interests must consider this inherent conflict.

Courts and scholars long have recognized that whatever is added to the field of defamation or privacy is taken from the field of free debate. ${ }^{244}$ First amendment evaluations norinally create a tension between public safety and free expression-both socially important values. ${ }^{245}$ Thus, society feels the impact of the decision to sacrifice either. ${ }^{246}$ The benefits of free expression are thought to outweigh the dangers of false or unwise statements, at least so long as there is sufficient time for corrective discus-

truly democratic system there is no need to protect popular expression. Public accountability should ensure that officials would not remain long in their positions if they regularly disregarded public sentiment. The governmental limitation incorporated into the first amendment is significant only if it protects unpopular expression-expression that the community will not act to support. See, e.g., T. Emerson, Toward a General Theory of the First Amendment 9-10, 16 (1966). The first amendment prevents the majority from controlling the expression of the minority. See A. DE TOCQUEVILLE, DEMOCRACY IN AMERICA 235-51 (New York 1838) (the real danger of tyranny in America was the tyranny of the majority).

241. The absolute relativism accepted by the orthodox theory of the first amendinent strips law of any substantive basis upon wlich to justify evaluations of what constitutes the "true" or "best" ideas or perspectives. This relativism, when viewed as an outgrowtl of free speech's negative justification, does not refute the possibility to search and find the true or best, but only maintains the inappropriateness of these designations being made by government institutions.

242. See Hudgens v. NLRB, 424 U.S. 507, 520-21 (1976); Erznoznik v. City of Jacksonville, 422 U.S. 205, 209-12 (1975); Police Dep't v. Mosley, 408 U.S. 92, 95 (1972). See generally Ely, Flag Desecration: A Case Study in the Roles of Categorization and Balancing in First Amendment Analysis, 88 Harv. L. Rev. 1482 (1975); Karst, Equality as a Central Principle in the First Amendment, 43 U. CHI. L. Rev. 20, 26-35, 65-67 (1975).

243. This confiict between reason and decency is the theme of an earlier article. See Ingber, Defamation: A Conflict Between Reason and Decency, 65 VA. L. REV. 785 (1979). The following discussion of defamation is largely based on ideas from this prior work.

244. See New York Times Co. v. Sullivan, 376 U.S. 254, 273 (1964); Pierce v. Capital Cities Communications, Inc., 576 F.2d 495, 503 (3d Cir. 1978); Afro-American Publishing Co. v. Jaffe, 366 F.2d 649, 664 n.1 (D.C. Cir. 1966); Sweeney v. Patterson, 128 F.2d 457, 458 (D.C. Cir.), cert. denied, 317 U.S. 678 (1942); Sinchak v. Parente, 262 F. Supp. 79, 85 (W.D. Pa. 1966); see also M. NIMMER, A TREATISE ON FREEDOM OF SPEECH § 2.05[C][1] (1984); F. SCHAUER, supra note 239, at 32.

245. Z. ChafeE, FREEDOM OF SPEECH 38 (1920).

246. Traditionally, free speech is the rallying cry of individual freedom, and control of speech is defended as necessary for the public good. The typical settings for this confiict-e.g., protests against war, racism, and governmental institutions-usually assure that any damage occurring through the protection of speecl is sliared by the community in such forms as the fear of violence, insurrection, and obstruction. 
sion. ${ }^{247}$ An appropriate balance is thus struck between these two social interests with society both reaping the benefits and bearing the burdens.

The burden of limiting suits for defamation and privacy invasion, however, is not shared generally by the populace. Rather, it falls directly and immediately upon the injured individual. Those injured may be unable to obtain redress through the legal system because of first amendment interests. When this occurs, the value of free speech is subsidized by the injured individuals rather than by the populace that benefits from a system of free expression. ${ }^{248}$ Consequently, intangible injuries to reputation and privacy create a unique problem for the legal system not found in intangible injuries generally: a direct conflict between important social values and the danger that legal support of one will jeopardize the other.

Nowhere is the tension between these free speech and decency interests greater than in the context of the American press. ${ }^{249}$ With the rise of the press's pervasiveness, power, and importance in our society, the tension between these interests increases. Consequently, pleas for governmental protection from "irresponsible" journalism become more frequent. ${ }^{250}$ The following two Sections focus upon the means by which our legal system has and should resolve this tension involving the intangible injuries of defamation and privacy invasion.

247. Whitney v. California, 274 U.S. 351, 377 (1927) (Brandeis, J., concurring) ("If there be time to expose through discussion the falsehood and fallacies, to avert the evil by the processes of education, the remedy to be applied is more speech, not enforced silence.").

248. The apparent inequity of sacrificing the individual for the good of the community led Justice White to comment:

It is difficult for me to understand why the ordinary citizen should himself carry the risk of damage and suffer the injury in order to vindicate First Amendment values by protecting the press and others from liability for circulating false information. . . . The owners of the press and the stockholders of the communications enterprises can much better bear the burden. And if they cannot, the public at large should somehow pay for what is essentially a public benefit derived at private expense.

Gertz v. Robert Welch, Inc., 418 U.S. 323, 392 (1974) (White, J., dissenting).

In response to Justice White's suggestion that the press internalize the injury it generates, one Comment warned that the benefit to society gained from the publication of a possibly false news story may be much greater than the benefit the publishing paper received in terms of increased circulation or prestige. Comment, Strict Liability Versus Negligence: An Economic Analysis of the Law of Libel, 1981 B.Y.U. L. REv. 398, 400-06. Consequently, even if the societal value of publication were high, a newspaper might refrain from printing an item if it feared liability.

249. The tenn "press" will be used to encompass all media of communication that are engaged in gathcring, reporting, and commenting on news.

250. Paton, Reform and the English Law of Defamation, 33 ILL. L. REv. 669, 670 (1939) ("[T]he corollary of the great power of the modern press is a strict sense of responsibility for the reputation of those who lie at their mercy . . . ."); see, e.g., Briscoe v. Reader's Digest Ass'n, 4 Cal. 3d 529, 533, 483 P.2d 34, 37, 93 Cal. Rptr. 866, 869 (1971) ("Acceptance of the right to privacy has grown with the increased capability of the mass media and electronic devices with their capacity to destroy an individual's anonymity, intrude upon his most intimate activities, and expose his most personal characteristics to public gaze."). 


\section{B. The Problem of Defamation}

\section{Description and Critique of the Present Remedy System}

Prior to 1964, the common law utilized a modified system of strict liability for defamatory statements made by the press. Causes of action for libel possessed three characteristics: liability without fault, ${ }^{251}$ a presumption of damages, ${ }^{252}$ and limited availability of defenses for truth ${ }^{253}$ and privilege. ${ }^{254}$ Such a system initially seems an attractive means to

251. The plaintiff needed only to present the derogatory statement and prove that the defendant was responsible for uttering or publishing the statement to others who were capable of understanding its defamatory meaning. W. PROSSER, supra note $1, \S 114$, at 776. The plaintiff did not need to prove that the statement was false. Id. $\S 116$, at 798. The burden was on the defendant to prove truth as an affirmative defense. As for intent, the plaintiff was not required to show that the defendant knew of the statement's falsity, or even that the defendant would have discovered it false in the exercise of due care. See, e.g., Jones v. E. Huiton \& Co., [1909] 2 K.B. 444 (C.A.), affd, [1910] A.C. 20 (P.C.). Because innocent defannation could cause as much harm as intentional defamation, the common law did not distinguish between the two but chose to hold all defaners strictly liable. Thus, expression-whether printed, written, or spoken-was placed in "the same class with the use of explosives or the keeping of dangerous animals." W. ProsSER, supra note 1, $\S 113$, at 773.

252. The plaintiff in a common law hbel suit also did not have to prove he suffered any actual injury to his reputation as a result of the defamatory statement. See generally 1 F. HARPER \& F. JAMES, supra note 69 , at $\S 5.9$; W. PROSSER, supra note $1, \S 112$, at $762-63$. Because of the concern that a clearly defamed plaintiff might be unable to prove actual damages, the common law irrebutably presuined injury to reputation as a inatter of law. General damages thus were pernitted without proof of actual loss. The general dainage award included actual out-of-poeket pecuniary loss (when it could be shown) and intangible danages-for example, for lessened esteem in the cyes of others. See D. DoBBS, supra note $182, \S 7.2$, at 513-14. Courts commouly also pennitted punitive damages upon a showing of inalice. Id. at 522 .

While critics recognized that juries might use general damages punitively, see Note, An Alternative to the General-Damage Award for Defamation, 20 STAN. L. REV. 504, 506-07 (1968), the presumption of injury and general damages was allowed as a necessary evil to assure compensation of deserving plaintiffs. See Gertz v. Robert WeIch, Inc., 418 U.S. 323, 394 (1974) (White, J., dissenting); W. Prosser, supra note $1, \S 112$, at 765; Developments in the Law-Defamation, 69 HARV. L. REv. 875, 884, 891-92 (1956) [hereinafter cited as Developments]. Consequently, the amount of damages that a plaintiff inight recover was highly speculative. Awards, often with no apparent rationale, varied from a few cents to thousands of dollars. W. PROSSER, supra note $1, \S 112$, at 76I.

253. Truth was a complete defense, but under the coininon law "trnth" meant literal truth. If, for example, the defamatory statement related that the plaintiff had been arrested three times for moral infractions when he had been arrested only once, the cominon law requirement of truth would not have been inet. See W. Prosser, supra note $1, \S 116$, at 798 . The harshness of this rule for defendants led most Annerican courts and legislatures to require only substantial truth. See, e.g., Florida Publishing Co. v. Lee, 76 Fla. 405, 411-12, 80 So. 245, 246 (1918); Maguire v. Vaughan, 106 Mich. 280, 286, 64 N.W. 44, 46 (1895); Minn. Stat. Ann. $\$ 609.765(3)$ (West 1964). Some jurisdictions required the defendant to prove that his motives in conveying the truth were good rather than malicious. Franklin, The Origins and Constitutionality of Limitations on Truth as a Defense in Tort Law, 16 STAN. L. Rev. 789, 792 (1964). The more common rule, however, was that truth was always a defense, regardless of motive. Id. at 790-91.

254. A defendant might also defend on the basis that his statements were absolutely or conditionally privileged. Absolute privileges prohibited suits regardless of malice and generally were limited to official participants in processes of government. The privilege was grounded on the belief that it benefited the public to have officials doing their jobs, unencumbered by fear of litigation. Barr v. Matteo, 360 U.S. 564, 569-72 (1959). Among the justifications advanced for the absolute privilege were the uncertainty of jury behavior, the danger of jury bias, and the time and expense of litigation. 
protect reputational interests. Courts frequently have recognized that erroneous statements injurious to reputation are inevitable in the media. ${ }^{255}$ Because of the rapid dissemination and mass distribution of information by the media, there is a substantial risk of accidental harm. By this analysis, the press inay be compared to highly desirable but unavoidably dangerous instrumentahities whose owners should insure the public against the harm they inevitably will cause. ${ }^{256}$ It would seem appropriate, therefore, to impose some form of strict hability on the press. $^{257}$

The media can more effectively avoid and absorb the risk of defamation than can its victim. Defamation does not strike the ordinary individual frequently enough to warrant his imsuring against it, so the victim can only protect himself by perpetually avoiding situations that may attract press coverage. On the other hand, because publishers are aware of the risk of libel, they can take steps to decrease its likelihood. ${ }^{258}$ In addition, pubhishers can treat madvertent hability as a cost of their enterprise by creating fund reserves for compensation. The cost of creating those reserves can be dispersed through their pricing structures to readers and advertisers. Thus, those who benefit from the press' activity would also pay the cost.

If decency were the only interest involved in the legal response to defamation, strict hability would function well indeed. However, the value of free expression is also important. The Supreme Court recognized this fact in New York Times Co. v. Sullivan. ${ }^{259}$ Beginning with this case, the Court proceeded to constitutionalize the law of defamation. The Court realized that although the common law defense of truth is essential and constitutionally mandated, that defense alone insufficiently satisfies first amendnient needs. ${ }^{260}$ Tlie process of ascertaining truth is simply too uncertain and risky.. For example, if a publisher knows his defamatory statement is true, he must still consider the possibility that a

A conditional privilege existed when the defendant published his statement to fulfill a public or private duty to speak, whether the duty was legally or morally based. There was also a conditional privilege for statements made to protect one's legitimate interests. The plaintiff could defeat the privilege by proof that the defendant pubhished the statement with malice. Developments, supra note 252 , at 930 . The common law never precisely defined malice, but often referred to the ill will or other wrongful states of mind of the defendant. See W. PROSSER, supra note 1, § 115, at 794.

255. Gertz v. Robert Welch, Inc., 418 U.S. 323, 340 (1974); Time, Inc. v. Hill, 385 U.S. 374, 388-89 (1967); New York Times Co. v. Sullivan, 376 U.S. 254, 271-72 (1964).

256. See discussion of ultrahazardous activities supra text accompanying notes $95-99$ and note 99.

257. The press is in a much better position to make a cost benefit analysis between injury costs and injury avoidance costs than is the class consisting of their potential victims. See supra note 125 .

258. For example, publishers can hire more conscientious reporters, obtain information from more reliable sources, or avoid publishing unverified statements.

259. 376 U.S. 254 (1964).

260. Id. at $278-79$. 
court will hold otherwise and impose hability. ${ }^{261}$ Even more importantly, a publisher may occasionally publisl material mistakenly believed to be accurate. Because it is often either not feasible or not possible to verify every statement with demonstrable certainty, ${ }^{262}$ a publisher must choose to either publish and risk hability or refrain from publishing to avoid the risk. The Court acknowledged that "[a] rule compelling the [publisher] to guarantee the truth of all [liis] assertions and to do so on pain of libel judgments virtually unlimited im amounts-leads to ... 'self-censorslip.' "263 The Court hoped to avoid the danger that, in an uncertain situation, a risk-averse publisher might self-censor and avoid controversial subjects. ${ }^{264}$

Self-censorship, however, is notling more tlian anotlier word for deterrence. Of course, the law of defamation must foster some deterrence if it is to protect the reputation of individuals. Consequently, when courts shield the press from liability in the imterest of free expression, they place the burden of defaination on the injured parties who, presumably, are less capable of either avoiding or imitigating injury. Given the importance of free expression, however, the "chilling" of the press is fundamentally different from the deterrence of other injury-causing activities. Using tort liability to deter the press froin publishing false statements may result in over-deterrence. A rule penalizing falsity actually may induce self-censorship of statements that are in fact true.

Before Sullivan, two additional factors increased the risk of press self-censorship. First, permittimg general or inferred dainages in defamation cases created a risk of fraud and abuse. Lacking any heavy evidentiary responsibility, the plaintiff could easily fabricate reputational injury. Moreover, juries, without any guidelines to evaluate evidence of injury, ${ }^{265}$ could use damages to punish unpopular defendants. General damages also created the risk that innocent or negligent statements miglit subject the defendant to virtually unlimited liability. ${ }^{266}$ This was

261. Error is possible in any fact-finding process. J. FRANK, CourTS ON TRIAL 15-16 (1949).

262. "[E]rroneous statement[s] [are] inevitable in free debate. . . ." New York Times Co. v. Sullivan, 376 U.S. at 271.

263. Id. at 279.

264. At one time it was believed that a system of free expression was adequately fostered by restriction against prior restraint alone. See 4 W. BlACKSTONE, Commentaries *152. See also Near v. Minnesota ex rel. Olson, 283 U.S. 697, 713-14 (1931) (citing syinpathetically Blackstone's view). But the Supreme Court in 1964 thought the chilling effect on speech caused by the anticipation of after-the-fact punishment and the other factors discussed in this Section clearly indicated the insufficiency of merely prohibiting prior restraint. Fear of libel suits could cause self-censorship as effectively as fear of criminal statutes. See New York Tines Co. v. Sullivan, 376 U.S. at 277-78.

265. "[I]n no other area of tort law does the jury so lack guidelines in the determination of damages." Franklin, supra note 151, at 11.

266. This was precisely the risk feared by the New York Court of Appeals in Ultramares Corp. v. Touche, 255 N.Y. 170, 179, 174 N.E. 441, 444 (1931) (public accountants found liable for fraud, but not for negligence). See supra note 224 and accoinpanying text. 
especially true for publishers of widely circulated newspapers because they could be subject to suit in any jurisdiction where they were read. Under such conditions, publishers might have been discouraged from publishing controversial material, and if sued, might have preferred to settle rather than face the vicissitudes of a jury trial. ${ }^{267}$

Second, the expense and mconvemence of litigation served to further discourage publication. Even if a publisher ultimately prevailed in the legal system, he would be forced to bear substantial litigation costs. ${ }^{268}$ Plaintiffs thus were encouraged to bring even groundless suits in the hope that their nuisance value might result in settlement offers. Consequently, the mere possibility of suit might have dissuaded publication even when the publisher believed he ultimately would prevail.

The Court has attempted in the last twenty years to reduce the risk of self-censorship while still protecting the imterest in reputation. It responded to the danger of self-censorship by limiting both the extent of liability and the amount of damages resultimg from publication of a defarnatory statement. On the liability side, the Court held that public persons (public officials and public figures) may recover for defamation ouly upon a showing of "clear and convincing proof that the defamatory falsehood was made with knowledge of its falsity or with reckless disregard for the truth."269 The Court found such knowing falselıods to be of "no essential part of any exposition of ideas." 270 Thus, no unwarranted self-censorslip would result from imposing liability for the publcation of statements known or believed false by their utterer-those published with what tlie Court termed "actual malice."271

267. See C. MCCormick, supra note 12 , at 443.

Apart from the occasional traceable money loss recovered as special damages, damages in defamation cases are measurable by no standard which different men can use with like results. Amounts of verdicts vary froin'nominal damages of a few cents to a fortune in six figures, according to numberless factors, such as the age, sex, wealth, and personal attractiveness of the parties, the skills of the respective counsel, the pungency of the defaming words, and the infinite variety of the experiences, sympathies, and prejudices of the Id. jurymen.

268. The cost of defendimg a hibel suit from discovery through trial and appeal begins at about $\$ 20,000$ and can run inuch higher. LeMaistre, Who Needs Egg on His Face?, JuRIS Dr., May 1974, 33, 34; see also Dugger, A Report to Our Friends, TeX. OnSERVER, Feb. 14, 1975, at 17. The successful defense in one suit eventually reaching the United States Supreme Court, for example, is reported to have cost nearly $\$ 100,000$. See Ek, Libel Insurance, in H. NELsON \& D. TeETER, LAW OF MASS Communications 666, 678 (2d ed. 1973).

269. Gertz v. Robert Welch, Inc., 418 U.S. 323, 342 (1974). See also Curtis Publishing Co. v. Butts, 388 U.S. 130, 162-65 (1967) (Warren, C.J., concurring); New York Times Co. v. Sullivan, 376 U.S. at $279-80$ (1964).

270. Garrison v. Louisiana, 379 U.S. 64, 75 (1964) (quoting Chaplinsky v. New Hampshire, 315 U.S. 568, 572 (1942)); see also Oeala Star-Banner Co. v. Damron, 401 U.S. 295, 301 (1971) (White, J., concurring).

271. New York Times Co. v. Sullivan, 376 U.S. at 280. The use of the term "actual malice" suggested that the same standard would be applied here as was necessary to overcome a common law 
In defamation suits brought by private persons against the news media, the Court held that states could adopt a standard less than actual malice so long as they did not impose liability without fault. ${ }^{272}$ Private persons must prove at least negligence. The crucial issue, therefore, is who qualifies as a public figure. An individual may qualify as a public figure in one of two ways. First, "an individual may achieve such pervasive fame or notoriety that he becomes a public figure for all purposes and im all contexts."273 Second, an individual may inject himself or be drawn into a public controversy, ${ }^{274}$ thereby becoming a public figure for a limited range of issues. These two types of plaintiffs do not require the same protection as does the private person because they "commanded sufficient continuing public interest and had sufficient access to the means of counterarguinent to be able 'to expose through discussion the falsehood and fallacies' of the defamatory statements."275

In addition to limiting the extent of liability, the Court sought to avoid chilling by limiting damages as well. It held that a private individual who could not prove malice could recover only for "actual" rather than presumed ijjury. ${ }^{276}$ The Court beheved that jury verdicts for general or presumed damages without specific proof of injury were often

conditional privilege. However, the common law standard included bad motives, see supra note 254, while the standard set by the Court was limited to knowledge of falsity or reckless disregard of the truth or falsity of the statement. The Court's standard seemed closer to that of "scienter." See W. Prosser, supra note $1, \S 118$, at 821 . Reckless disregard meant that there was sufficient evidence to conclude that the defendant had serious personal doubts of the truth of his published statements. See St. Amant v. Thompson, 390 U.S. 727, 731 (1968).

272. Gertz v. Robert Welch, Inc., 418 U.S. at 347-48. The Court thus left the states some leeway in decidimg the standard for defamation of private individuals. Most states and the RESTATEMENT have adopted the lower negligence standard. RESTATEMENT (SECOND) OF TORTS $\S 580 \mathrm{~B}$ (1977). Some states, however, sucl as Indiana and Colorado, impose the higher malice requirement if the defamatory statement concerns an issue of public interest. See Walker v. Colorado Springs Sun, Inc., 188 Colo. 86, 98-99, 538 P.2d 450, 457, cert. denied, 423 U.S. 1025 (1975); Cochran v. Indianapolis Newspapers, Inc., 175 Ind. App. 548, 557-58, 372 N.E.2d 1211, 1219 (1978).

273. Gertz v. Robert Welch, Inc., 418 U.S. at 351.

274. Id. The Court has observed, at least hypothetically, that a person may become a public figure through no purposeful action of his own. However, "the instances of truly involuntary public figures must be exceedingly rare." Id. at 345; see Wolston v. Reader's Digest Ass'n, 443 U.S. 157, 166 (1979) (person "dragged unwillingly" into controversy not public figure).

275. Curtis Publishing Co. v. Butts, 388 U.S. 130, 155 (1967) (citation omitted). The Court suggested two points. First, in a manner closely analogous to assumption of risk in torts, public officials and figures have invited attention and comment by thrusting themselves into the forefront of public controversies. They therefore should not complain when they do not like public reaction, because, in effect, they have asked to be judged. Second, public officials and figures are seen as less vulnerable to injury than private individuals. The public person enjoys greater access to effective channels of commumication. In short, the system of free expression supplies a sufficient remedy for such persons by providing them an opportunity to contradict the lie or correct the error. See id. at 164 (Warren, C.J., concurring).

276. Gertz v. Robert Welch, Inc., 418 U.S. 323, 349-50 (1974). Thus, although only private figures ean receive damages without proof of malice, both public and private figures may continue to recover presumed and punitive damages if they establish liability by clear and convincing proof that 
based more on the unpopularity of the speech at issue than on any actual harm done to the plaintiff. ${ }^{277}$ Accordingly, the Court limited those occasions when the jury could grant general or presumed damages.

Recognizing the difficulty of proving actual injury, ${ }^{278}$ the Court softened the consequences of this restriction. It did not limit damages to out-of-pocket/pecuniary loss. Rather, it held damages could imclude impairment of reputation, personal humihation, and mental anguish and suffering. Although all awards required support by competent evidence, "there need[ed] be no evidence which assigns an actual dollar value to the imjury." 279

During this period of activity, the Court hoped to preserve first amendment values, yet still protect reputational interests. The Courts' efforts, however, have been generally unsuccessful in protecting either one's reputation or first amendment values. Currently, the law of defamation fails both to insulate the press from self-censorship pressures and to protect adequately the individual's reputation.

Despite the Court's attempt to reduce the dangers of self-censorship, libel litigation appears not only to have survived but to be thriving. ${ }^{280}$ The trend actually is for greater damage awards and higher settlement

the defamatory falsehood was made with knowledge of its falsity or with reckless disregard of the truth. Id. at 348-50.

As this issue went to press, the Supreme Court decided Dun \& Bradstrect, Inc. v. Greenmoss Builders, 53 U.S.L.W. 4866 (U.S. June 26, 1985). The Court restricted the scope of Gertz by holding that a private individual need not prove "actual malice" to recover presumed and pumitive damages provided the defamatory statements do not involve "matters of public concern." Id. at 4869 . The Court did little, however, to clarify what constitutes a "matter of public concern." Consequently, the Dun \& Bradstreet decision likely ensures the continued thriving state of defamation litigation. See infra text accompanying notes 280-81.

277. The Court in Gertz concluded:

The largely uncontrolled discretion of juries to award damages where there is no loss unnecessarily compounds the potential of any system of liability for defamatory falseliood to inhibit the vigorous exercise of First Amendment freedoms. Additionally, the doctrine of presumed damages invites juries to punisil unpopular opinion rather than to compensate individuals for injury sustained by the publication of a false fact.

Id. at 349 .

278. Mucl of the structure of defamation law derives from a recognition that injury to reputation is difficult to demonstrate, even when serious liarm has resulted. 1 F. HARPER \& F. JAMES, supra note $69, \S 5.30$, at 468 . It may be difficult to identify and locate persons in the commumity who think less of the plaintiff because of the publication, especially when the defamatory statement has been indiseriminately circulated. Furthermore, ouly the rare witness will admit to the plaintiff or testify in court that his opinion of the plaintiff lias changed because of the publication, especially when by so doing lie admits that he changed his opinion without determining the truth or falsity of the statement.

279. Gertz v. Robert Welch, Inc., 418 U.S. 323, 350 (1974). See Time, Inc. v. Firestone, 424 U.S. 448, 460-61 (1976); cf. RESTATEMENT (SECOND) OF TORTS $\S 623$ (1977) ("One who is liable to another for [defamation] is liable also for emotional distress . . . that is proved to have been caused by the defamatory publication.").

280. See Anderson, Libel and Press Self-Censorship, 53 TEx. L. REv. 422, 430 (1975). 
agreements. ${ }^{281}$ The Court's approach is defective because it operates at the wrong end of the litigation. In most cases, ${ }^{282}$ the rules limiting liability merely changed the instruction under which the case is submitted to the jury. Juries thus retain considerable discretion. ${ }^{283}$ Jury animosity toward the press may partially explain the frequency of verdicts for plaimtiffs. The traditional jury bias favoring plaintiffs may be most pronounced in suits involving unpopular defendants who have made defamatory statements about popular individuals or causes. ${ }^{284}$ People tend to react negatively to statements which are contrary to their convictions or present an unfavorable picture of groups to which they belong. The Court's rules, which retain the pivotal role for unpredictable and potentially biased juries, fail to remove the threat of costly litigation and, therefore, the likelihood of self-censorship.

Additionally, the Court's efforts have failed to reduce the incentive for nuisance suits. Because a factual determination of the defendant's actions prior to publication is central to the Court's liability-limiting standards, the defendant incurs a major portion of defense costs before the trial stage. ${ }^{285}$ To the extent that juries are predisposed against the

281. See Smolla, supra note 3, at 1-14. Recent studies by the Libel Defense Resource Center (LDRC), a New York based information clearinghouse organized by media groups to monitor developments in libel law, reveal a dramatic increase in the size of damages awarded at trial although many awards are later reduced or reversed on appeal. See Libel Defense Resource Center, Bulletin No. 4, Oct. 15, 1982, at 3-4 [heremafter cited as LDRC Bulletin No. 41; Libel Defense Resource Center, Bulletin No. 7, July 15, 1983, at 58 [heremafter cited as LDRC Bulletin No. 71. The typical damage award is now in the millions of dollars. LRDC Bulletin No. 7, supra, at 58. One LDRC study showed that thirty out of forty-seven awards included punitive damages, and seven of those pumitive damage awards were for $\$ 1$ million or more. LDRC Bulletin No. 4, supra, at 3, 5 \& table 2, $6 \&$ table 2-B. More recent data from the LDRC indicate punitive damage awards arc even more pervasive, witl such awards now averaging "almost $\$ 8$ million per pumitive award." Libel Defense Resource Center, Special Alert, July 29, 1983, at 1.

282. By clianging the substantive elements of defamation, the rules-particularly the "actual malice" rule-do preclude a few plaintiffs from reacling the jury. The plaintiff, under the aetual malice rule, must prove malice with "convincing clarity," New York Times Co. v. Sullivan, 376 U.S. 254, 285-86 (1964), and failure to meet this burden makes a summary judgment or directed verdict for the defendant appropriate. See Hutclimson v. Proxmire, 579 F.2d 1027 (7th Cir. 1978), rev'd on other grounds, 443 U.S. 111 (1979).

283. "When a libel case gets to a jury, the First Amendment kind of drops to the wayside." Jenkins, Chilly Days for the Press, STUDENT LAw., Apr. 1983, at 23, 28 (quoting Henry Kaufman, General Counsel of the Libel Defense Resource Center).

284. Professor Marc Franklin discussed this jury bias:

In some cases a popular plaintiff has been the subjeet of the defamation; in some an unpopular publication is the defendant. Sometimes that publication is from another part of the country and the plaintiff is local. The impact may be enhanced if the plaintiff is a public official whose defamation lias also east a bad light on the community itself. Although a jury from the plaintiff's commumity is probably best able to ineasure liarm to reputation, it is also less likely to be a completely impartial panel.

Franklin, supra note 151, at 8-9; see also supra text accompanying notes 29,151 and note 151 .

285. Systeins demanding careful case-by-case consideration involve high tertiary costs. See supra note 125 . 
press, ${ }^{286}$ the media may be able to win many of these cases only on appeal. ${ }^{287}$ The cost of defending a libel suit thus remains high and the settlement value of nuisance suits remains undiminished.

The Court also has failed to respond adequately to the danger that the potential of substantial damage awards will lead to media self-censorship. It has authorized presumed or punitive damages only when liability is based on actual malice. In all other circumstances, the jury can award only "actual damages." These limitations, however, have failed to reduce the chilling impact of large awards. Presumed damages still remain available where malice is proven. Consequently, the awards in successful hibel actions are often considerable. ${ }^{288}$ Although successful actions are rare under the actual malice standard, the possibility of windfall damages probably lures some plaintiffs into court. The fear of substantial judgments presumably chills publishers and further pressures media defendants to settle rather than risk the outcome of litigation. ${ }^{289}$

Tlie limitation to "actual damages" for hability based on negligence provides little greater protection. Aware of the difficulty in proving actual injury, ${ }^{290}$ the Court did not limit such damages to calculable and transferable costs. Damages are proper where the plaintiff can demonstrate "impairment of reputation and standing in the community, personal humiliation, and mental anguish and suffering."291 Once the plaintiff lias produced some evidence of emotional injury-such as his own testimony-tlie jury may infer the nature and extent of that injury and the award appropriate for compensation. Thus, although a jury may not presume emotional injuries, it still may infer them. Such an insignif-

286. See supra text accompanying note 265. The Court's abstract doctrinal scheme cannot be intelligently evaluated without considering its real-world consequences. For example, unless the defendant admits the intentional communication of falsehood required under the "actual malice" test, scienter can only be inferred from circumstantial evidence. Since this evidence is often the internal content and credibility of the counmunication, even under the more stringent of the two Court created liability standards, the jury may effectively pass critical judgment on political opinion.

287. Furthermore, even the chance of success on appeal is hikely hinited to cases tried under the actual malice standard. One study found that no case tried on a neghigence standard had been reversed exclusively on an appellate ruling that the jury's finding of negligence was erroneous. Libel Defense Resource Center, Bulletin No. 6, Mar. 15, 1983, at 35, 42.

288. See, e.g., Curtis Publishing Co. v. Butts, 388 U.S. 130, 138 (1967) (jury awarded $\$ 3,060,000$, reduced by trial court to $\$ 460,000$ ); Goldwater v. Ginzburg, 414 F.2d 324, 328 (2d Cir. 1969) (\$1.00 actual damages, $\$ 75,000$ punitive damages), cert. denied, 396 U.S. 1049 (1970); Burnett v. National Enquirer, Inc., 144 Cal. App. 3d 991, 997, 1018-19, 93 Cal. Rptr. 206, 208, 223 (1983) (jury awarded $\$ 1.6$ million, reduced by trial court to $\$ 800,000$, further reduced on appeal to \$200,000); Field Research Corp. v. Patrick, 30 Cal. App. 3d 603, 605, 106 Cal. Rptr. 473, 474 (\$150,000 actual damages, \$150,000 pumitive damages), cert. denied, 414 U.S. 922 (1973).

289. The normal suit filed by public officials or public figures now seeks damages in the multimillions. See Smolla, supra note 3, at 2-4. The mere prospect of a judgment of such magnitude, even if only occasionally upheld, must seriously concern the editorial offices of the press.

290. See supra note 278.

291. Gertz v. Robert Welch, Inc., 418 U.S. 323, 350 (1974). 
icant change is unlikely to reduce substantially the amount of awards. Given the flexibility in calculating damages in defamation suits, the jury clearly retains the power to punish the press. ${ }^{292}$ Considered together, the combination of the uncertainty and high cost of litigation, the pressure to settle claims, and the potential of extensive liability strongly encourage press self-censorship.

Ironically, while the Court's efforts have failed to reduce media selfcensorship and adequately protect first amendment values, they have also inadequately protected certain reputational interests. First, the Court's culpability standards may prevent certain plaintiffs from recovering damages even where their injury is clear and their losses are both calculable and transferable. ${ }^{293}$ Consequently, these plaintiffs must internalize the cost of the injury themselves, and, in effect, subsidize an industry which is itself better able to both avoid and absorb such losses. ${ }^{294}$ They lack any method of vindication or even a ineans of formally setting the record straight. ${ }^{295}$ Second, even when plaintiffs can prove liability and obtain a money judgment, the remedy is not likely to reestablish their reputation in the community. ${ }^{296}$ Financial compensation for the truly intangible aspects of reputational loss is not possible. Rumor, like pain, still continues. In summary, the present systent of liability for defamation does not reestablish the planitiff's reputation and does not coinpensate the plaintiff rationally, yet it continues to threaten or chill communication. ${ }^{297}$ An alternative system nuust be sought.

\section{An Alternative Remedy System}

The damage system proposed in Part I is an attractive starting point

292. Professor Alfred Hill thus warns: "A jury inclined to excess can indulge this inclination quite easily on the basis of the testimony of one or inore witnesses friendly to the plaintiff, and indeed can go far with the plaintiff's own testimony of mental suffering." Hill, Defamation and Privacy Under the First Amendment, 76 CoLUM. L. REV. 1205, 1252 (1976).

293. For example, under the present law, a defamed private individual who cannot prove negligence, and a defamed public figure who cannot prove malice, may not recover damages. This holds even though the defamatory statement may have led to the libeled party being dismissed from his employment or becoming sufficiently distressed to require medical attention. The pecuniary losses attached to these injuries are easily calculable and transferable.

294. See supra text accompanying note 258.

295. The public may view attempts by the injured party to refute the defamatory statement as self-serving and unrehable when these efforts are unsupported by a court determination.

296. Such a judgment

seldom comes to the attention of one tenth of the people who read the [defamation] and who remain under the impression created by the offending publication. [The plaintiff] is met by a conspiracy of silence on the part of the press as [defamation] suits against newspapers, by professional courtesy, usually are not reported.

Donelly, The Right of Reply: An Alternative to an Action for Libel, 34 VA. L. REv. 867, 873-74 (1948); see also Pierce, The Anatomy of an Historic Decision: New York Times Co. v. Sullivan, 43 N.C.L. REV. 315,347 (1965).

297. Franklin, supra note 151 , at 2. 
for developing an improved remedy scheme for defamation. Regardless of the plaintiff's status-whether he is a public or private person ${ }^{298}$ courts should award damages for actual pecuniary loss, for example, lost income and psychological therapy expenses. Such damages in defamation contexts, however, are rare, generally fixed, and certainly himited. Consequently, to the extent that the size of damage awards causes selfcensorship, the chilling effect of damage awards if limited to pecumary loss would be minimized. ${ }^{299}$ Because the plaintiff will need to prove outof-pocket loss specifically, this approach removes the danger of punitive jury awards and allows the court to exercise greater control over the size of the award.

Because these pecuniary costs are clearly transferable, defendants should be held strictly liable for such damages. Pecuniary damages should be internalized as a cost of the activity that generated the injury and paid for by those benefiting from the activity. Even when dealing with the inevitable, fault-free defamatory statement, the inedia-consuming public should compensate the equally fault-free plaintiffs for injuries that are difficult to fabricate, ${ }^{300}$ and, being objectively calculable, are conipletely transferable.

Courts should grant awards for actual but nonpecuniary injuries ${ }^{301}$ where the plaintiff can denionstrate that the defendant knew of the falsity of his statement or recklessly disregarded personally held suspicions of its falsity. A reasonable inference may be drawn that under such circumstances the defendant would not have published the defamatory statement unless he thought and hoped it would injure the plaintiff. In such cases, it does not seem unjust to require the defendant to bear the actual damages resulting from his defamatory statenient. After all, the willful

298. The distinction between public and private persons has proven elusive, thus increasing the time and expense of litigation. Such increased tertiary costs only are desirable when counterbalanced by some societal gain. The present system's efforts to make this distinction have led only to a "decade of groping" rather than any societal benefit. Id. at 37. Professor Christie also has proposed a single standard of liability in defamation actions. See Christie, Injury to Reputation and the Constitution: Confusion Amid Conflicting Approaches, 75 MICH. L. REv. 43, 63-64 (1976); Christie, Underlying Contradictions in the Supreme Court's Classification of Defamation, 1981 DUKE L.J. 811, 821.

299. The press also inay be chilled if, following a jury finding of defamation, the public is made aware of the press' inaccurate reporting. Editorial chilling caused by the fear that knowledge of the defainatory behavior will spread is not, however, the kind of chilling the first amendment aims to prevent. See Red Lion Broadcasting Co. v. FCC, 395 U.S. 367, 390 (1969). In fact, public knowledge that defamation suits exist as a check against falsehood and damaging inaccuracy actually inay help the press by increasing the willingness of citizens to place faith in the truthfulness of press reports. Hunsaker, Freedom and Responsibility in First Amendment Theory: Defamation Law and Media Credibility, 65 Q.J. SPEECH 25 (1979).

300. If dainages are really for out-of-pocket losses, little financial incentive remains for a plaintiff to try to fabricate such injuries.

301. Such damages would not include the presumed/general damages presently available upon a showing of malice but only the nore limited "actual damages" now awardable in suits where only negligence is proven. See supra text accoinpanying notes 276-79. 
defendant can best evaluate consciously all risks prior to acting. In this context, restitutive justice is appropriate, and primary cost avoidance is both effective and desirable. In allowing nontransferable damages, the goal is precisely to chill-to avoid the externalization that might result in insufficient deterrence of the defamatory statement. ${ }^{302}$

To avoid the danger of overdeterrence, however, the proposed remedy system would not permit punitive damages. The threat of enormous and unregulated punitive damages may seriously threaten freedom of expression. ${ }^{303}$ For example, the danger that juries night award such damages against unpopular inedia defendants in situations where the publication was not willful might deter publishers from distributing innocent, though controversial, statements. ${ }^{304}$ Because such punitive damages may be uninsurable, ${ }^{305}$ permitting both actual and punitive damage awards inay chill all inedia publishers, not simply intentional tortfeasors.

Although the proposed systen for damages is an improvement over the systen created by the Court, it is, without further refinement, still an nisufficient protection of reputation. Under the proposed system no cause of action exists for a defamed plaintiff who can prove neither pecuniary dan1ages ${ }^{306}$ nor intentional wrongdoing. Some mechanisn is necessary to vindicate such a plaintiff's reputation, while imposing some responsibility on the defendant to be aware of his potential to injure. ${ }^{307}$ Even when noney damages are available, such judgments alone are likely not to draw sufficient public notice to, in Professor Clarence Morris's words, "quiet title" to plaintiff's reputation. ${ }^{308}$

302. Thus, as with other willful torts, property rather than liability rules of evaluation are preferable. See supra text accompanying note 175 and note 92 . The proposed system would encourage the negotiations and settlements essential to obtaining the proper evaluation under a property rulc.

303. See Wheeler v. Green, 286 Or. 99, 119, 593 P.2d 777, 789 (1979) (punitive damages in defamation cases found to violate statc constitution's protection for freedom of expression). The proposed remedy system recognizes that general, presumed, and punitive damages all serve less a compensation and more a punishment/deterrence function. It is thus troubling when a plaintif who has already received compensation for nonpecuniary injuries also recovers significant punitive damages, which are justified by a need to punish the defendant.

304. The danger that a punitively-prone jury may find seienter where none exists is discussed infra text accompanying note 319.

305. Lankenau, Public Policy Limitations on the Insurability of Punitive and Actual DamagesPart I, in Media Insurance 165 (J. Lankenau ed. 1983) (Practising Law Institute, Course Handbook Series).

306. Any attempt to limit the dangers of general damages must recognize that even plaintiffs whose reputations are truly injured may find out-of-pocket damages difficult to prove. See supra note 278 .

307. A realization of this unfulfilled need led Justice Brennan, in Gertz v. Robert Welch, Inc., to note that states might be permitted to enact legislation "not requiring proof of fault, which provide[s] for an action for retraction or for publication of a court's determination of falsity if the plamtiff is able to demonstrate that false statements have been published concerning his activities." 418 U.S. 323, 368 n.3 (1974) (Brennan, J., dissenting).

308. C. MORRIS, Inadvertent Newspaper Libel and Retraction, in STUDIES IN THE LAW OF TORTS 314,317 (1952). 
Fortunately, an array of nonmonetary remedies exist that may meet these needs without inducing self-censorship. For example, any individual feeling wronged should be able to bring a simple action for a declaratory judgment affirming the false ${ }^{309}$ and defamatory nature of the defendant's statement about him. Such a judgment would help vindicate the plaintiff as well as legitimize any subsequent reply or retraction. ${ }^{310}$

Even declaratory judgments, however, are inadequate. Often they cannot restore the injured party's reputation in the community because they are insufficiently publicized, especially in comparison with the defamatory statement. Consequently, a defendant against whom a declaratory judgment is rendered should be required to choose between publishing a retraction or financing the reasonable costs of a reply elsewhere. ${ }^{311}$ Compensation for reply costs, however, should be contingent upon the plaintiff inaking a good-faith effort to obtain media reply time or space without charge. ${ }^{312}$ This additional remedy assumes that correc-

309. Any system of remedy for defamation, imcluding the one proposed, requires either a judge or jury to determine whether the statement at issue is false. Thus a legal institution, in a manner inconsistent with orthodox first amendment theory, is choosing between truth and falsity. This problem may be avoided only by granting the media absolute immunity froin suit.

Although we may justifiably question any governmental attempt to suppress opinion upon the basis of official certainty of the opinion's falsity, see supra text accompanying notes 239-40, some judicial determmations of truth may be consistent with that posture. In virtually every kind of case, juries make determinations of fact which are, in essence, determinations of truth. But as Professor Frederick Schauer cautions, such determinations do not signify certainty.

More than in most other areas of enquiry, it is crucial here to distimguish knowledge from certainty. We can approach a standard measure, such as the standard metre, by narrowing the range of tolerance (increasing the degree of accuracy) even if we can never exactly duplicate the standard metre. So too can we approach truth, or acquire knowledge, despite the lack of absolute certainty. The lack of certainty does not, as some have inistakenly argued, mean that no uncertain behef is preferable to any other. Even if we can never achieve 100 per cent certainty, we can still prefer 99 per cont assurance to 55 per cent assurance, which in turn is better than 6 per cent assurance. In this context we can describe the search for truth, or the search for knowledge, as the search for beliefs of which we are more confident, rather than as the searcl for beliefs of which we are absolutely certain.

F. SCHAUER, supra note 239 , at 18.

Some speech, such as discussions of aesthetics, fall into categories least subject to verification. Other categories of expression involve factual or otherwise verifiable propositions. There the possibility of error is significantly smaller. This is most often the case in defamation. Professor Marc Franklin lias suggested a method of protection from even this residual danger. Franklin would eliminate any determination of falsity in defamation suits unless the plaintiff could prove that falsity with "convincing clarity." Franklm, supra note 151, at 40. As Franklin put it: "[d]ebatable propositions should be debated and not adjudicated." Id. at 40 n.178.

310. As stated earlier, supra note 295 , a reply unsupported by any court determination may be viewed by the public as self-serving and, consequently, unreliable.

311. The reply must be limited to the defamatory issue decided in the court proceeding and of equal scope to the defamatory remark.

312. Courts, in varied areas of the Iaw, frequently must inake determinations of good-faith efforts. See, e.g., U.C.C. $\$ 2-103$ (1966). There is no reason to believe this determination will be more difficult or complicated in the reply context. 
tive statements are more helpful than money damages ${ }^{313}$ in restoring a person's reputation following a defamatory publication. ${ }^{314}$ This assumption, in turn, is in accord with the first amendment faith that the best remedy for falsity is more speech. ${ }^{315}$

Allowing the defendant to choose between publishing a retraction or financing a reply avoids the danger of governmental encroachment on editorial prerogatives. It also lessens the impact of individuals' varying degree of access to channels of communication. ${ }^{316}$ If the defendant chooses to retract his original statement, the language of the retraction will be his own and not the plaintiff's. Furthermore, a defendant wishing to stick by his former statement may continue to do so. ${ }^{317}$ However, he then inust compensate the plaintiff for any reasonable costs necessary to make an adequate reply elsewhere. ${ }^{318}$

Since the remedy scheme focuses on those lacking ready media access, reply costs should be awarded only where the plaintiff can show reasonable efforts to obtain cost-free media coverage. As a matter of practice, therefore, reply costs probably will be required only when the defamatory statement concerns what is currently called a private individual rather than a public official or figure. Indeed, where defamation arises in the reportmg of matters of public interest, even a private individual probably will have access to the inedia for reply purposes.

The proposed remedy scheme recognizes the existing clash between

313. They are also less likely than money damages to engender media chilling through the jury's punitive use of award judgments.

314. While everyone who read or heard a defamatory statement might not subsequently encounter a published retraction or reply, such efforts at correcting earlier false accusations are certainly more likely to restore reputation than are the quiet entries of judgments on the musty rolls of courts. The justices themselves, at least arguably, have realized this fact. See Gertz v. Robert Welch, Inc., 418 U.S. 323,344 \& n.9 (1974).

315. Whitney v. California, 274 U.S. 357, 377 (1927) (Brandeis, J., concurring).

316. With the commumication explosion, media organizations have accumulated vast amounts of privilege and power. Monopolistic practices and economies of scale have made it difficult for new ventures to enter the field of mass communication. See F. THAYER, LEgal CoNTrol of THE Press $\S 22$, at 128-30 (4th ed. 1962). Owners and managers of the press may determine which persons, facts, and ideas will reach the public. Courts should take these access differentials into account when fashioning remedies for defamation.

317. Thus, Miami Herald Publishing Co. v. Tornillo, 418 U.S. 241 (1974), is inapposite. In that case, the Court struck down a statute requiring the defendant newspaper to publish the reply of a legislative candidate whicl the paper had assailed. Of course, the court must determine whether the retraction is adequate, contains no insinuations, is not a hypotletical or hesitant withdrawal, and presents no new calumnies in disguise. But if agreement between the court and the defendant is not reaclied, the defendant may refuse to retract and opt instead to finance the plaintif's reply elsewhere.

318. This remedy scheme recognizes the varying degree of access individuals have to the media, yet it does not create the general "right of access" rejected by the Supreme Court in CBS v. Democratic Nat'l Comm., 412 U.S. 94 (1973) (political advertiser had no constitutional right to require media to sell air time) and Tornillo, 418 U.S. 241 (1974). Only those plaintiffs who have secured through the court a right of reply or retraction are granted access. Further, it is not mandated that this limited right be assured exercise in any specific forum. 
reputation and first amendment values without rejecting either of the competing perspectives. It treats both sides in the conflict with respect and sympathy, achieving an accommodation between thein. The reinedy scheme aims to bring us somewhat closer to an optimal point for both interests by delimiting the risk of excessive money damages while expanding alternative remedies.

Under the proposed system, however, there is still the danger that a jury sympathetic to the plamtiff will find the requisite scienter where none exists. This problem also is present under the current law, although appellate review limits the danger somewhat. If the jury, trial judge, and appellate judges are all simultaneously prejudiced against the media defendant, ouly absolute immunity or the permanent limitation of damages to pecuniary loss would protect it. Both alternatives would sacrifice the individual's reputation interest to even malicious and fraudulent publication. At least the proposed system improves on the present one by eliminating punitive damages and by liniting nonpecumary damages to situations where the plamtiff has a heavy burden of proof.

However, this danger of a jury's wrongfully finding intent deinands further refinement of the generally proposed scheine for willful torts. Unlike the case of willful torts causing pain and suffering or emotional distress, ${ }^{319}$ media defendants found to have willfully defamed should not be subject to subrogation suits brought by their insurance carriers. The costs of nonpecuniary damages should not be borne by a single defendant. Rather, the media as a whole should bear such costs as part of an insurance pool. Thus, for example, a biased jury could not financially destroy a small newspaper through an extravagant judgment for nonpecuniary loss. Nonetheless, such a system would motivate the industry to regulate itself and prevent irresponsible reporting. ${ }^{320}$

Additionally, by substantially eliminating general damages, the proposed remedy system must address the problem of attorney fees. Part I suggested a inethod for compensating intangible injuries which included reasonable fees awards. ${ }^{321}$ In the context of no-fault actions for defamation, however, awards for attorney fees may increase the danger of nuisance suit settlements, chill editorial courage, and, consequently, increase pressures for primary cost avoidance. Awarding attorney fees against defendants in such contexts, therefore, may unduly retard first amend-

319. See supra text following note 92.

320. Although, on first blush, it may seem inequitable to force nonmalicious members of the media to subsidize the malicious members of the industry through insurance, the media itself continues to clamor for self-regulation. See, eg., The First Amendment and Professional Broadcast Journalism, Remarks by Thomas M. Wyman, Chairman and Chief Executive Officer of CBS, at the Sloan Colloquium in Communications, Duke University (February 5, 1985) (suggesting media selfregulation makes it unnecessary as well as unwise for government to regulate the media).

321. See supra text accompanying notes $186-89$. 
ment interests. Consequently, fees should be granted only where the plaintiff proves negligence or willfulness. When both plaintiff and defendant are deemed to be innocent of negligent or intentional wrongdoing, both parties should assume their own attorney fees. ${ }^{322}$ Where the defendant is not without fault, he should bear the cost of any corrective hitigation. The threat of hability for plaintiff's attorney fees presumably would encourage settlements and some primary cost avoidance. Where the defendant is at fault, limited incentives for self-control seem appropriate.

Finally, it is worth noting that under this remedy proposal, courts and juries no longer would need to distmguish between public and private figures. Consequently, tertiary costs would be reduced significantly. ${ }^{323}$ Perhaps more importantly, however, courts would cease to be involved in a decisional process imconsistent with orthodox first amendment doctrine. A major function often attributed to the first ainendment is to limit the government's power to decide what the public does and does not have a right to know. ${ }^{324}$ The concept of freedom of expression means hittle if government can determine what speech may be initiated. Although limitations on speech are sometimes necessary, ${ }^{325}$ significant restrictions on governmental control over expression are vital to prevent government from mainipulating the thinking processes of our society.

In spite of this concern, the Supreme Court's rules for defamation cases require a delicate deterinination of what the public has a right to know. Deciding whether an individual who voluntarily participated in a controversy $^{326}$ should be classified as a public figure for a specific issue

322. Since the fault levels here are reciprocal, concepts of restitutive justice do not place the equities with either party. See generally Fletcher, supra note 97.

It may be asked, however, whether plaintiffs will bring suit for small amounts of pecuniary damages if they must also pay their own attorney fees. Two responses are possible. First, the proof requirements for these suits are mimimal. The plaintiff only need show that the statements were made, that they were false and defamatory, and, if alleging actual damages, that he suffered pecuniary loss. Therefore, except when the question of truth is seriously litigated, attorney fees should be less than if the plaintiff had to prove negligence or intent. Presumably, the plaintiff may absorb these reduced fees more easily.

Second, because the proposal's focus when dealing witl fault-free defendants is not primary cost avoidance, it is appropriate that suits be brought only by those strongly committed to gaining vindication or so seriously pecuniarily damaged as to make suits worthwlile. These two classes of plaintiffs are precisely those most needing a cause of action for purposes of secondary cost avoidance. These plaintiffs, who are unable to prove defamation with malice or negligence, currently have no remedy available. The proposal is clearly an improvement on the present state of the law.

323. As noted earlier, the distinction has proven clusive, demanding a considerable allocation of court time and concern. See supra note 298.

324. Professor Meiklejolin stressed that under the first amendment, "What is essential is not that everyone shall speak, but that everything worth saying shall be said." A. MEIKLEJOHN, POLITICAL FREEDOM 26 (1960). But who determines if something is "worth saying"?

325. For example, limitations on fraudulent statements, perjury, and false advertisement.

326. See supra discussion of the concept of "public figure" in text accompanying notes 272-75. 
requires the court to determine whether it was a "public controversy."327 Yet government evaluations of the "appropriateness" of specific subjects for public concern is precisely what ortlodox first amendment theory forbids.

Permitting courts to determine if something is deserving of general public concern often results in a constitutional debate among judges as to the justifiability of the public receiving information about a person or event. $^{328}$ The standard the Supreme Court has developed, however, requires repeated ad-hoc evaluations of whether the contested publication was inerely catering to public curiosity or was conveying information about a controversey in which the public had a justifiable interest. The remedy package for defamation proposed in this Article removes the need for such constitutionally suspect evaluations. Unfortunately, such deteruninations may be unavoidable in suits for invasion of privacy.

\section{The Problem of Privacy Invasions}

\section{The Essence of Privacy}

Less than a century ago a cause of action expressly for an invasion of privacy was unknown to the common law. The tort developed in response to an article written in 1890 by Samuel Warren and Louis Brandeis. ${ }^{329}$ The authors concluded that a new tort was needed because "[i]nstantaneous photographs and newspaper enterprise [had] invaded the sacred precincts of private and domestic life" and because "[t]he press [was] overstepping in every direction the obvious bounds of propriety and of decency." 330 Unless a cause of action was created to deal with the inore flagrant breaches of decency, they feared the ultimate result would be the destruction of "robustness of thought and delicacy of feel-

327. This need for a court determination is extremely ironic, for the Court specifically refused in Gertz v. Robert Welch, Inc., 418 U.S. 323 (1974), to extend the "actual malice" rule to statements concerning issues of public interest. The Court rejected the proposed "public interest" standard for fear that it committed to state and federal judges the task of deciding "on an ad hoc basis which publications address[ed] issues of 'general or public interest." " Id. at 346. Yet under present Courtmade rules, the existence of a public controversy, although alone insufficient to mandate the greater press privilege, see Wolston v. Reader's Digest Ass'n, 443 U.S. 157 (1979), is still a necessary finding before a court will impose the malice burden. See id. at 166 n.8, 167-68.

This irony is heightened by the Court's recent opinion in Dun \& Bradstreet, Inc. v. Greenmoss Builders, 53 U.S.L.W. 4866 (U.S. June 26, 1985), limiting the Gertz damage restriction by allowing a private individual to recover presumed and punitive damages without proving malice when the defamatory statements do not involve matters of "public concern." See supra note 276.

328. For example, in Time, Inc. v. Firestone, 424 U.S. 448 (1976), Justice Rehnquist, writing for the Court, and Justice Marshall, dissenting, strongly disagreed as to whether reports of the divorce proceedings between socialite Mary Alice Firestone and her millionaire husband involved public figures within a public controversy. Compare id. at 454-55, with id. at 484-90 (Marshall, J., dissenting). See also Wolston v. Reader's Digest Ass'n, 443 U.S. 157 (1979).

329. Warren \& Brandeis, The Right to Privacy, 4 Harv. L. REv. 193 (1890).

330. Id. at 195-96. 
ing" in the society at large. ${ }^{331}$

As technological development and popular migration into cities began to transform society, the Warren/Brandeis article struck a responsive chord. By 1980 virtually all jurisdictions had recognized a "right of privacy" in one form or another. ${ }^{332}$ But the common law growth of the right has been sporadic. No coinprehensive profile has developed from which to justify and define the right. ${ }^{333}$ This Article will focus only on that aspect of privacy which involves public disclosure of personal facts. ${ }^{334}$ It is in this context that the clash between privacy and the first amendment is inost pronounced. ${ }^{335}$ The "right to privacy" in such a setting consists of the right to determine for oneself the extent to which one will share with others one's thoughts, one's feelings, and the facts of one's personal life.

Before proceeding, however, a further distinction must be made between disclosures the plaintiff finds objectionable because they detract froin his stature in the community and disclosures objectionable because of the information's intimacy. While a false statement which detracts is justifiable grounds for a suit in defamation, publication of true information which detracts may be inerely setting the record straight. Consequently, the plaintiff who wishes to sue because of such a disclosure, essentially, is hoping to continue to inisrepresent himself to the public. Such an interest deserves little public sympathy or legal recognition.

Quite different is the plaintiff who suffers the publication of intimate facts. The essence of such injuries is the mass dissemination of facts not relevant to issues of public concern and thus not justifiably within the

331. Id. at 196

332. By 1980, only Rhode Island had not recognized a right of privacy in some form. PROSSER \& KEETON, supra note $29, \S 117$, at 851 . The scholarship in this area has also been considerable. E.g., A. Westin, Privacy AND Freedom (1967); Bloustein, supra note 230; Davis, What Do We Mean By "Right to Privacy"?, 4 S.D.L. REv. 1 (1959); Gross, The Concept of Privacy, 42 N.Y.U. L. REv. 34 (1967); Konvitz, Privacy and the Law: A Philosophical Prelude, 31 LAW \& CoNTEMP. ProBs. 272 (1966). An extensive list of the early writings following the Warren/Brandeis article may be found in W. Prosser, supra note $1, \S 117$, at $802-03$ n.9.

333. Bloustein, Privacy, Tort Law, and the Constitution: Is Warren and Brandeis' Tort Petty and Unconstitutional as Well?, 46 TEx. L. REv. 611, 615 (1968); Kalven, Privacy in Tort Law-Were Warren and Brandeis Wrong?, 31 LAw \& ConTEMP. ProBs. 326, 333 (1966).

334. Prosser, reviewing the developing case law, concluded that four privacy interests ratler than a single interest had developed: the interest not to have one's name or likeness appropriated by another for his gain or benefit, not to have one's seciusion or solitude unreasonably and offensively intruded upon, not to have true but highly personal facts about oneself disclosed to the public, and not to have publicity place one in a false light in the public eye. W. ProssER, supra note $1, \S 117$, at 804-14.

335. Other areas of privacy, for example, intrusion upon one's solitude, may involve no first amendment issue at all. The press has no greater right than has any other member of the public to invade an individual's home to ascertain facts about him. See Houchins v. KQED, Inc., 438 U.S. 1 (1978); Saxbe v. Washington Post Co., 417 U.S. 843 (1974); Pell v. Procunier, 417 U.S. 817 (1974). 
public domain. Professor Milton Konvitz writes of such a view of privacy:

Its essence is the claim that there is a sphere of space that has not been dedicated to public use or control. It is a kind of space that a man may carry with him, into his bedroom or into the street. Even when public, ... . it is a part of his "property". . . with respect to which its owner has delegated no power to the state. ${ }^{336}$

For example, when the press relates a man's emotional crisis upon being forced to leave his wife and children, the wrong is found in the fact that "a private life has been transformed into a public spectacle."337 This unjustified transformation attacks the essential core of the right to privacy, ${ }^{338}$

To some extent the injury caused by a privacy invasion, inuch like defamation, is a specific type of emotional distress. ${ }^{339}$ The renedy proposal developed in Part I, therefore, may be apphicable. Compensation could be available for specific, pecuniary losses, such as the costs of psychological therapy, relocation to another commumity, or loss of wages following discharge from employment. ${ }^{340}$ General damages for intangible injuries would be unavailable unless the plaintiff could prove the injury was willfully inflicted. ${ }^{341}$

However, the main impetus for an action for invasion of privacy is not the emotional distress the invasion causes. The focus is more on the protection of human dignity than on compensation for loss. Once an intinate fact has been publicly disclosed, otliers will know of it and the resulting injury-indignity and humiliation-cannot be rectified. In defanration the availability of declaratory judgnents, retractions, and replies all serve to remedy the intangible damage caused by the reputational

336. Konvitz, supra note 332 , at 279-80,

337. Bloustein, supra note 333 , at 619 .

338. Of course cases may arise in which a single disclosure both reveals facts of an intimate nature and detracts from one's stature in the community, for example, the revelation to a Catholic clurch congregation that one of its members lias had an abortion. However, the essence of a cause of action for the privacy invasion should be the intimate nature of the facts revealed rather than the damage to stature.

339. "It is only because, lumamity being constituted as it is, the feelings are deeply outraged by the exposure to public gaze of intimate private matters, that some courts liave raised the interest in privacy to the dignity of a legal right." Magruder, supra note 78, at 1062 n.124.

340. Obviously the loss of one's job is more likely to occur if the disclosure detracts than if it merely reveals an intimacy. Although statements that are merely detractive should not constitute a tort, see supra text accompanying notes 335-38, publication of intimate facts that also detract should justify awards that compensate for the pecuriary ramifications of both the lost privacy and the lost stature. Needless to say, a court must determine that the sensitivity of the plaintiff is not so umique as to require him to absorb even the pecuniary costs of his emotional response. The jury evaluation of "proximate cause" could readily serve this function.

341. Willfulness, in order to constitute sometling close to scienter, would necd to be defined not merely as intent by the defendant to disclose specific information, but as intent to upset the plaintiff by disclosing something known or suspected by the defendant to be outside of the public domain. 
injury. No coinparable remedies exist for invasions of privacy. Unlike virtually all other areas of coinmunication, more speech or information can never rectify the wrong. ${ }^{342}$ Consequently, the justification for invasion of privacy actions is less to correct past wrongs than to discourage future transgressions. ${ }^{343}$ These suits serve prinary cost avoidance goals. Their main purpose is to deter or "chill" the media-precisely those purposes which the Supreme Court found inost troubling in the context of defaination suits. Therefore, a careful constitutional analysis of a "right to privacy" is suggested.

\section{Constitutional Analysis}

The theoretical justification for removing private issues from the robust debate encouraged by the first amendment can be stated fairly simply. Constitutional rules generally are rules to order and regulate group living. They are rules of the collectivity. The right of privacy, however, msulates a portion of mdividual hife from the group, creating a doinain excluded froin collective hife and thus not governed by the rules of collective living. ${ }^{344}$ Consequently, the rules safeguarding the right of privacy supersede those constitutional rules and rights, including first amendment rights, that focus on group dynamics.

The Supreme Court in Griswold v. Connecticut ${ }^{345}$ and Roe v. Wade $^{346}$ recognized a constitutional right of privacy. Griswold insulated from governmental regulation an individual's decision whether to use contraceptive devices. Roe did the same for a woman's decision to abort a fetus during the first trimester. These decisions involve significant values of inorality, life, and liberty. Democratic theory suggests that elected legislative bodies are generally best suited to make decisions requiring such a choice among values. ${ }^{347}$ In fact, before Roe, nany state legisla-

342. Nimmer, The Right to Speak from Times to Time: First Amendment Theory Applied to Libel and Misapplied to Privacy, 56 CALIF. L. REv. 935, 961 (1968).

343. An argument may even be made that those persons who file suit, by that very act, have shown themselves least sensitive to public exposure and therefore least in need of a remedy. To gain personal vindication, such litigants liave demonstrated a willingness to initiate a process likely to further disclose their claimed intimate fact. A certain callousness to further public disclosure is therefore necessary. Those most sensitive are likely to avoid furtler notoriety. However, suits by the more callous must be allowed in order to deter future mjury to those too sensitive to try to vindicate their own interests.

344. T. EMERSON, supra note 232, at 562.

345. 381 U.S. 479 (1965).

346. 410 U.S. 113 (1973).

347. Congress, for example, may employ preferential racial quotas to foster equality even though other government and private institutions may not lave a comparable power to reject claims of individual merit. E.g., Fullilove v. Klutznick, 448 U.S. 448, 473 (1980) (upholding a federal program giving preferential treatment to businesses owned by members of minority races in awarding of public contracts). The Court in Fullilove noted "[h]ere, we pass, not on a choice made by a single judge or a school board, but on a considered decision of the Congress and the President." 
tures were in the process of considering the abortion issue. The Court in Roe halted this process, not by deciding whether abortion itself was right or wrong, but by determining that the choices involved in an abortion decision were within the province of the individual and not the public. Therefore, group deliberative processes were inappropriate.

Of course, all invasions of privacy do not constitute violations of constitutional rights justifying civil rights suits in addition to tort actions. ${ }^{348}$ However, the force of the constitutional recognition that soine areas of an individual's life fall outside of the group domain affects all issues in close proximity. It creates a force field that has an impact on cultural attitudes toward privacy generally. The result is that, unlike the value of reputation in the defamation context, the value of privacy inay constitute a counterforce of perhaps equal syinbolic and societal influence to the values embodied in the first amendinent. Because the first amendinent specifically protects freedoin of speech and press while there is no comparable constitutional protection of reputation, ${ }^{349}$ a bias may justifiably exist when dealing with defamation favoring errors of too mucl rather than too little commumication. ${ }^{350}$ In contrast, in privacy invasion cases there inay be a more equal balance between the significance of first amendment and privacy values. Consequently, no preference may exist toward errors affecting one ratlier than the other interest. The danger of chilling the media may be no greater when privacy rather than reputation is at stake, but the societal price of insufficient deterrence may weigh more leavily in the privacy case.

Unfortunately, the simplicity of the conceptual rationale for restricting discussion of private issues or facts is misleading. The rationale assumes general agreement as to what constitutes an intimate issue.

348. In any case, most civil rights statutes require that the violation be 'under the color of law.' E.g., 42 U.S.C. $\S 1983$ (1982).

349. The Court has specifically rejected the view that reputation is a hiberty or property interest protected by the fourteenth amendment due process clause. Paul v. Davis, 424 U.S. 693 (1976). There is a marked contrast between the treatment of reputation in defamation cases where it is seen as "a basic of our constitutional system," Gertz v. Robert Welch, Inc., 418 U.S. 323, 341 (1974) (quoting Justice Stewart's concurring opinion in Rosenblatt v. Baer, 383 U.S. 75, 92 (1966)), and in due process cases where it is found not to be "a candidate for special [constitutional] protection," Paul v. Davis, 424 U.S. 693, 701 (1976).

Professor Rodney Smolla explains this apparent two-facedness:

The Supreme Court freely manipulates reputational values, either enhancing or dimimishing their importance as it sees fit. Perplexingly, the unifying principle appears to be that reputation will be given whatever level of importance is necessary to undermine other constitutional guarantces. The importance of reputation is built up by the Court when such a build-up helps decrease the coverage of the first amendment's free speech guarantees; the importance of reputation is dismantled when the dismantling serves to constrict the scope of the due process clause.

Smolla, supra note 3 , at 16 n.84.

350. F. SCHAUER, supra note 239, at 171 ("[A]n error of over-suppression or over-deterrence [of speech or press] is treated more seriously than an error of under-protection of reputation."). 
Under such conditions application problems would not arise. ${ }^{351}$ In applying this rationale to privacy actions, however, the difficulty may not be in developing a cogent theory of control but in properly identifying what is to be controlled. Who is to determme whether an issue or fact falls outside the public's legitimate concern and how is that determination to be made? If one asks the individual about whom the disclosure is made, he may label as private that which merely detracts. ${ }^{352}$ If this question is asked of the the press, they may claim protection for salacious gossip. ${ }^{353}$ Authorizing courts to determine what is intimate forces judges to make ad hoc decisions as to what issues the public may justifiably take an interest $m$ and what facts are relevant to this public agenda. ${ }^{354}$ There is always danger when government decides the extent of the public's "need to know."

It is not an easy matter to decide whether a particular truth is or is not in the public interest. Any judicial attempt to so categorize communications would impose on the public a court's view of "proper" societal concerns. ${ }^{355}$ Envision, for example, a situation in which the press reveals that a primary school teacher is gay. The reporter may state his belief that homosexuality is immoral and immoral individuals should not teach

351. A similar presumption was accepted in the obscenity field and has proven extremely unrealistic. With the exception of very few Justices, for example, Justices Blaek and Douglas, the Supreme Court has generally agreed that obscenity could be banned, censored, or regulated without first amendment difficulties. Such regulation, however, would be permitted only to the extent that the material, in the words of Roth $v$. United States, was "utterly without redeeming social importance." 354 U.S. 476, 484 (1957). However convincing was the Court's general rationale for government control of pornography, over the years since the Roth opimion in 1957, the Court has found it exceedingly difficult to determine which coinmunications lack such social value. See, e.g., Miller v. Califorma, 413 U.S. 15 (1973) (relaxing Roth standard). Yet without a clear distinction between publicly valuable and nonvaluable communication it is impossible to ensure that proper regulation of one will not result in the improper regulation of the other. See Paris Adult Theatre I v. Slaton, 413 U.S. 49, 79-80 (1973) (Brennan, J., dissenting).

352. The distinction between disclosures that detract and those that reveal intimacies is discussed supra at text accompanying notes 335-38.

353. It is not enough for the press simply to be required to pay its own way, for sueh payinents would only truly compensate the plaintiff for pecuniary loss. Compensation may not restore one's privacy or dignity. Thus, the only way to retain privacy is to deter the initial disclosure. Deinanding that the press inerely compensate out-of-pocket loss would, in essence, empower the press to forceably purchase another's privacy interests.

354. This is precisely the result that the Court found unacceptable in Gertz v. Robert Welch, Inc., 418 U.S. 323, 346 (1974). See supra notes 327-28 and accompanying text.

355. Even judicial rejection of what soine would perceive as being simply gossip would constitute such an ideological and aesthetic imposition. As Professor Smolla has aptly stated:

There are certaiuly as many Americans who find the vivid low brow discourse of the tabloid more relevant and interesting than the endless dissections of the President's budget message in the mainstream press. To many, the romantic life of Elizabeth Taylor or Michael Landon either revcals more of the human condition or provides inore of a relief from the mundane routines of daily life than the statistical machinations of David Stockinan. There is nothing in the text of the first amendinent to indicate that it is aimed at proteeting only elitist speeeh preferences.

Smolla, supra note 3 , at 41 . 
children or serve as their role models. ${ }^{356}$ The reporter also may insist that even if the teacher retains his position, both parents and school board members need to know of his sexual preference so they may closely monitor the teacher's behavior around his students. ${ }^{357}$ All members of the community may agree that those aspects of the teacher's life that have no legitimate connection with his fitness to teach should remain private and undisclosed. Some community members likely will believe that an individual's sexual preference among adults is such a purely private issue. Others, however, will agree fully with the reporter's arguments. $^{358}$ These people probably would feel gravely wronged if the information was not revealed and they later discovered that they intentionally were kept uninformed.

Whenever a governmental institution decides that a given fact, such as an individual's sexual preference, is not a fitting topic for public discussion nor relevant to any issue of public concern, it is essentially inposing an ideological perspective on society. Professor Walter Weyrauch, considering the issue of relevance in the trial context, found it a "useful conceptual tool for discarding arguments and evidence that challenged significant and usually unspoken societal values." 359 Relevance, when used in the field of privacy, is also an evaluative rather than descriptive concept; it is tied to how people ought to think, feel, and behave. $^{360}$ The clash of values created by privacy suits is obvious. On one hand, such suits are necessary if an individual's private doinain is to be protected and his dignity guarded. On the other hand, these suits may interfere with commumity meinbers' access to information. Although some may believe the information is significant, access to it will be denied if others-specifically judges and juries-beheve it ought not be relevant. Under orthodox first amendment doctrine, such a formal imposition of perspective ${ }^{361}$ is inherently suspect. ${ }^{362}$

356. Of course, it can be argued that role modeling would not be a problem had the teacher's sexual preference not been disclosed in the first place.

357. The reporter would be accepting the stereotype of homosexuals that views them as likely to proselytize their lifestyle among the young.

358. A parent whose child has been asked by the teacher to stay after school to help reorganize the classroom may find this information vital to deciding whether to grant permission.

359. Weyrauch, Law as Mask-Legal Ritual and Relevance, 66 CAL1F. L. REv. 699, 709 (1978).

360. See generally Comment, The Right of Privacy: Normative-Descriptive Confusion in the Defense of Newsworthiness, 30 U. CH1. L. REV. 722 (1963).

361. The danger of such an inposition has led some scholars to believe that, in spite of any positive value privacy suits may contribute, they should be constitutionally impermissible. E.g., F. Haiman, SPeech and LAW in A Free Soclety 75, $85-86$ (1981).

362. Some writers have insisted that the dangers inherent in governmental selection of the public agenda and determination of relevance do not apply to privacy suits, where decisions are made not by governmental officials but by a jury not beholden to any governmental authority. E.g., F. SCHAUER, supra note 239, at 175-76. Juries, however, because of their variable nature, increase litigation uncertainty. This uncertainty results in greater danger of chilling and seemingly arbitrary inconsistencies among judgments. Additionally, experience with defamation eases reveals that 
Unfortunately, case law rarely has been sufficiently sensitive to this tension between values. Many court decisions, while upholding privacy interests, ${ }^{363}$ have developed only vague standards which are subject to substantial jury discretion. These decisions may encourage media selfcensorship, and thus threaten the public's access to information. ${ }^{364}$ The inost influential of these cases was Sidis v. F-R Publishing Corp. ${ }^{365}$

juries, when confronting first amendment issues, must be monitored by the courts. Bose Corp. v. Consumers Union of United States, Inc., 104 S. Ct. 1949, 1963-65, 1964 n.27 (1984). Some Supreme Court opinions have displayed pronounced misgivings about the propriety of juries distinguishing between public and private concerns. Consider, for example, the Court's opinion in Monitor Patriot Co. v. Roy, 401 U.S. 265 (1971). That defamation case involved a charge against a political candidate that he liad been a "small-time bootlegger" some three decades earlier. The trial judge left it to the jury to determine whether this statenent pertained to the candidate in his public or private capacity. The Suprene Court apparently believed that such questions should never be left to a jury. It stated that while a jury could be trusted to apply a standard of eare-which the Court deemed relatively "neutral"- -jurors would be given excessive "leeway to act as censors" if allowed to apply a standard of "relevance." The latter standard was one that the Court thought "unlikcly to be neutral with respect to the content of speech." Id. at 275-77. The Court's opinion strongly suggests that application of a standard of relevance to public concerns ultimately must be made by the court rather than the jury. Cf. Rosenblatt v. Baer, 383 U.S. 75, 88 (1966) (whethcr defamed person is public official is question for court); Rosanova v. Playboy Enters., Inc., 411 F. Supp. 440, 444 (S.D. Ga. 1976), aff'd, 580 F.2d 859 (5tl Cir. 1978) (same as to public figures, collecting authorities).

363. Several of these cases involved the exposure of a respected citizen's criminal records from a long-past youth. See Briscoe v. Reader's Digest Ass'n, 4 Cal. 3d 529, 483 P.2d 34, 93 Cal. Rptr. 866 (1971); Melvin v. Reid, 112 Cal. App. 285, 297 P. 91 (1931). Others involved disclosure of physically intimate facts and images. See York v. Story, 324 F.2d 450 (9th Cir. 1963), cert. denied, 376 U.S. 939 (1964) (police circulated nude pictures of plaimtiff taken by then allegedly as evidence of bruises resulting from an assault); Barber v. Time, Inc., 348 Mo. 1199, 159 S.W.2d 291 (1942) (publication of name and picturc of woman with humiliating disease).

364. Commonwealth v. Wiseman, 356 Mass. 251 , 249 N.E.2d 610 (1969), cert. denied, 398 U.S. 960 (1970), is a prine example of a situation in which privacy concerns led to a decision to keep the general public unaware of conditions in a public institution. In this, the so-called "Titicut Follies" case, the court sanctioned an injunction against unrestricted exhibition of a documentary film exposing conditions im a Massachusetts institution for the criminally insane. Inmates were shown in the most personal and private situations, with many scenes of nudity. The court viewed the film as an outrageously "indecent intrusion into the most private aspects of the lives of these unfortunate persons in the Commonwealth's custody." Id. at 258, 249 N.E.2d at 615.

Yet the concern of Massachusetts officials who mitiated this suit about the privacy of those filmed must be viewed with skepticism. The film's stark portrayal of patient routine and treatment was a scathing indictment of the inhumane conditions that prevailed in the institution and thus presented a serious embarrassnent for the state. In a lengthy dissent to the Supreme Court's denial of certiorari, Justice Harlan, joined by Justices Douglas and Brennan, stressed the inportance "that conditions in public institutions sliould not be cloaked in secrecy, lest citizens may disclaim responsibility for the treatnent that their representative government affords those in its care." 398 U.S. at 962 (Harlan, J., dissenting).

365. 113 F.2d 806 (2d Cir.), cert. denied, 311 U.S. 711 (1940). Sidis involved a New Yorker profile on a child prodigy who had achieved wide renown for mathenatical and other intellectual powers, but who as an adult held relatively nenial jobs and led a reclusive life. The lifestyle reflected, among other things, an obsessive concern with privacy. All this, the court said, was given "nuerciless" exposure in the profile, 113 F.2d at 807, with no apparent object but that of pandering to the curiosity of the public. The court added, however, that "the misfortunes and frailties of neighbors and 'public figures' are subjects of considerable interest . . . to the rest of the population. And when such are the mores of the community, it would be unwise for a court to bar their expression in the newspapers, books, and nuagazines of the day." Id. at 809. 
Although the court in Sidis refused to award dainages, it noted that it inight act otherwise in the case of "revelations . . . so intimate and so unwarranted . . . as to outrage the conımunity's notions of decency."366 This standard for liability has gained considerable support, ${ }^{367}$ yet its amorphous nature inay justifiably threaten any risk-averse publisher. The Restatement (Second) of Torts attempts to limit the impact upon first amendnient values by specifically exenipting from liability published materials of "legitiniate public interest."368 Yet the Restatement largely fails to provide a concrete standard for identifymg which materials qualify.

In determining what is a matter of legitimate public interest, account must be taken of the customs and conventions of the community; and im the last analysis what is proper becomes a matter of the commurity mores. The line is to be drawn when the publicity ceases to be the giving of information to which the public is entitled, and becomes a morbid and sensational prying into private lives for its own sake, with which a reasonable member of the public, with decent standards, would say that he had no concern. ${ }^{369}$

A publisher, prior to disclosure of any arguably private fact, must recognize that liability for invasion of privacy will depend upon an unpredictable jury determination of undefined nores of the particular community, and that the extent of the judgment against him may be substantial. ${ }^{370}$

Although a similar state of affairs led to Supreme Court intervention in the field of defaination, twice the Court has had an opportumity to consider the first aniendment ramifications of suits for the public disclosure of allegedly private facts, and botli times the Justices sidestepped the central constitutional issues. Time, Inc. v. Hill ${ }^{371}$ involved an article that appeared in Life magazine describing a play entitled The Desperate Hours. The play was an adaptation of a novel with the same title, which fictionalized an mcident in which a family had been held lostage in its honie by escaped prisoners. A similar incident had befallen the Hill family. The novel and play were clearly fictionalized and did not mention the naine of the Hill family; however, the Life article did. Published three years after the Hills' traunatic experience, the article made promi-

366. 113 F.2d at 809. This condition was thought not to be satisfied in the particular case, as a matter of law. But why this was so clearly a inatter of law the court did not undertake to explain.

367. This language of Sidis has even been quoted with some acceptance by the Supreine Court. Time, Inc. v. Hill, 385 U.S. 374, 383 n.7 (1967).

368. RESTATEMENT (SECOND) OF TORTS $\$ 652$ D comment h (1977).

369. Id.

370. When defendant's liability is determined entirely by the jury's sense of outrage, the everpresent danger of arbitrary enforcement in tort actions is accentuated. As Professor David Givelber has acknowledged: "factinders may confuse outrageous with unpopular so that fear of tort judgments might chill constitutionally protected (or at least socially important) behavior." Givelber, supra note 78 , at 52 .

371. 385 U.S. 374 (1967). 
nent use of the episode involving the family and falsely commented that the family's story was "re-enacted" in the play. The Court, rather than confronting the tension between the Hill family's desire to avoid further public notoriety and the paper's interest in reporting, focused instead on the inaccuracies in the article that miglit liave placed the Hills in a false light publically. To the Court, the gravamen of the claim concerning Life's article was its falsity. Having recently dealt with the issue of press inaccuracies in the defamation context, ${ }^{372}$ the Court handled the Hill case similarly. It remanded the suit for a determination of whether the publication was inade with "actual malice"-knowing falsehood or reckless disregard of suspicions of such falsehood. ${ }^{373}$ The Court thus avoided tlie first ainendınent probleins inherent in authorizing liability for truthful statements.

The privacy invasion issue inore clearly confronted the Court in Cox Broadcasting Corp. v. Cohn. ${ }^{374}$ A Georgia statute made it a misdemeanor to publicly disseminate a rape victim's identity. In violation of this statute, the defendant liad published a victim's name, which it ascertained by exaunining an indictment available for public inspection. The highest state court lield that this publication would sustain a cause of action for invasion of privacy. ${ }^{375}$ The Supreine Court reversed. The Court's opinion sweepingly proclaimed tliat the media was iınınune from liability for truthfully reporting information available to the public in "official court records"376 and presumably in other public records as well. The opinion, agam avoiding the core constitutional question, focused instead on the linguistic and symbolic inconsistencies of allowing a privacy invasion claim for publication of information available on public records. If, according to the Court, the state allowed the information to be disclosed to anyone who took the time to clieck the record, then those facts could not be labeled "private" when disclosed by the press.

But linguistic consistency does not necessary lead to sensitive decision-making. ${ }^{377}$ Only the extreinely callous can be oblivious to the realworld differences in privacy invasion between the disclosure of a personal

372. See New York Times Co. v. Sullivan, 376 U.S. 254 (1964).

373. Hill was decided after New York Times Co. v. Sullivan but prior to Gertz v. Robert Welch, Inc., 418 U.S. 323 (1974). Since the Gertz decision, which allows limited liability for defanatory publications about private figures upon a slowing of simple negligence, cases such as Hill might now be reinanded for a determination of negligence rather than scienter.

374. 420 U.S. 469 (1975).

375. Actually the rape victim was dead. It was her father's privacy that was deemed to be invaded by the publication. Cox Broadcasting Corp. v. Cohn, 231 Ga. 60, 62-63, 200 S.E.2d 127, 130-31 (1973), rev'd, 420 U.S. 469 (1975).

376. 420 U.S. at 495. The opinion in Cox Broadcasting thus may seriously deplete the precedential effect of those cases which hold defendants liable for revealing plaintiff' long-past criminal records. See supra cases listed at note 363.

377. In fact, froin a privacy standpoint whether the source of a disclosure is or is not a public record is of little practical consequence. As one commentator has noted: 
fact in a dusty public record hidden somewhere in the bowels of a county courthouse and a similar disclosure disseminated through the inass technology of the inodern press. ${ }^{378}$ The Court, responding to a common law development which was insufficiently sensitive to first amendment considerations, had written an opinion basically indifferent to the values of privacy. In addition, the Justices had failed to analyze carefully the constitutional difficulties inherent im suits for public disclosure of true facts. An alternative resolution avoiding botli of tlese flaws needs to be developed.

\section{Resolving the Conflict}

The value conflict inherent in a cause of action for invasion of privacy is considerably more difficult to resolve thian the conflict created by defamation suits. Yet if there is a constitutionally supported entitlement to privacy, ${ }^{379}$ it may justify a cause of action more fully tlian does the need to recognize an interest in reputation. The problen1, lowever, is that privacy suits also focus more exclusively on primary cost avoidance than do defanration suits; the fundamental goal of a privacy action is to deter or chill the media.

Moreover, the press is less able to protect itself froin liability for privacy invasion except througli self-censorship. A publisher seeking to avoid libel suits may use various techniques to check tlie accuracy of his

It is fiction to say that a newspaper drawing on public records is only making accessible what was constructively known by all before. Much gossip may be far more widely known than some matters of public record. If printing the name of a rape victim whose identity adds nothing to the story is an unprivileged invasion of privacy, why should it become privileged if the name of the woman appears somewhere in a mass of public records?

Franklin, A Constitutional Problem in Privacy Protection: Legal Inhibitions on Reporting of Fact, 16 STAN. L. REV. 107, 120-21 (1963). The "mass of public records" may inciude old voter registers, old registers of wills and deeds, and similar repositories of "pubhi" infornation. These actually inay be less accessible than back issues of a newspaper. In this sense they are less "public" than newspaper files.

378. An analogy can be made to the jurisprudence of the fourth amendment. In Katz v. Umited States, 389 U.S. 347 (1967), the Supreme Court recognized the fourth amendment's role in protecting privacy: "What a person knowingly exposes to the public, even in lis own home or office, is not a subject of Fourtl Amendment protection. But what he seeks to preserve as private, even in an area accessible to the public, may be constitutionally protected." Id. at 351 (citation omitted). This language, however, must be interpreted reasonably. If a person, living on the upper floor of a New York apartment building, did not drape his windows, he would be exposing his privacy to anyone who bothered to look witl the aid of higl-powered binoculars or a telescope. However, allowing this disclosure does not mean he lias chosen to waive his right to refuse entry by police officers who, without probable cause and a warrant, also wisl to view his lome. Nor does it mean that the individual viewing through lis telescope may also take pictures of what lie sees and distribute thein without facing liability. The limited possibility of disclosure allowed by the lack of drapes clearly does not end the apartment dweller's claims of privacy against the world in general.

379. See supra text accompanying notes 344-50. 
facts prior to public dissemination. ${ }^{380}$ A diligent newspaper staff thus may minimize the risk of defamation. No comparable techniques are available to test the public nature of a report prior to publication. Privacy, unlike falsity, is entirely an ideological concept. It cannot be empirically tested. A pubhisher can only guess how a judge or jury might assess a reasonable man's reaction. ${ }^{381}$ Witlout the ability to minimize the risk of hitigation by testing the public nature of a release, ${ }^{382}$ the media is discouraged from disclosing any arguably private facts even though many community members might find the information valuable.

The danger of media self-censorship increases further when the courts award general damages for nonpecuniary losses. ${ }^{383}$ Uncertainty as to hability will be compounded by uncertainty as to the damage potential of any given statement. Yet even the willful publisher who publishes hoping to humiliate the plaintiff must be protected if, in spite of his motives, the court determines his communication is both true and of public concern. A publisher's dishonorable motive does not, by itself, defeat his readers' or listeners' riglit of access to the information.

To avoid media chilling, any system designed to compensate for privacy invasions must reduce uncertainty both as to the conditions of liability and the extent of damages. To accomplish this goal, boundaries of privacy — of the personal domam outside of the collective interest-must be more clearly defined. The present system, which requires a jury to make case-by-case evaluations of the defendant's behavior against the yardstick of community mores, does not provide the clarity necessary for effective prior notice.

The Supreme Court's effort to avoid the vagueness problems of state

380. For example, he may seek to find multiple independent sources alleging the same facts and, thus, mutually verifying each other.

381. A reasonable man standard, due to its uncertainty, always will deter somewhat individuals from participating in injury-risking behavior. Such deterrence, while justified when dealing with activities such as driving, is highly problematic when it serves to "chill" constitutionally encouraged conduct. This realization led Justice Brennan to conclude that the crucial eleinent of the opinion in Cox Broadcasting Corp. v. Cohn, 420 U.S. 469 (1975), was the "determination that a "reasonable man' standard for imposing hability for imvasion of privacy interests" affords inadequate protection for the press because it fails to provide adequate prior notice. Time, Inc. v. Firestone, 424 U.S. 448 , 474 (1976) (Brennan, J., dissenting).

382. In effect the publisher is left to guess about his tort liability for privacy invasion in the same manner in which Justice Stewart's definition of "liard-core pornography" left a publisher with the need to guess about his criminal liability for conveying obscenity. Justice Stewart, with unequaled frankness, admitted: "I sluall not today attempt further to define the kinds of material I understand to be enibraced within [the concept of hard-core pornography]; and perhaps I could never succeed in intelligibly doing so. But I know it when I see it. . . ." Jacobellis v. Ohio, 378 U.S. 184, 197 (1964) (Stewart, J., concurring). A jury may know a privacy invasion precisely in the manner that Justice Stewart recognizes pornography. Yet in neither case may a publisher take much comfort.

383. Secondary cost avoidance goals alone may always justify granting damages to compensate for pecuniary losses due to a privacy invasion. But even then the jury first must make the essentially ideological decision that privacy, in fact, has been violated. 
obscenity statutes suggests an approach to privacy issues. Just as a statute is required to set out the contours of hardcore pornography, ${ }^{384}$ so should one be necessary to specify the kinds of facts deemed outside the public domain. ${ }^{385}$ To prevent situational factors such as claimant popularity and status from intruding upon the decisional process, such a statute would require that the states establish the boundaries of privacy at a high level of generality. ${ }^{386}$ This requirement would make the decisional process less likely to be purely self-serving and more likely to refiect generally accepted cultural mores. ${ }^{387}$ The probable result would be a timited list of matters deemed private, ${ }^{388}$ including bodily functions and sexual activities. There also likely would be some allowance for personal growth over time. ${ }^{389}$ Privacy protection would only discourage communications that touched the inner core of intimacy.

Violation of the privacy statute posed, conceivably, could be treated as a criminal offense. As discussed earlier, however, the criminal justice system is likely too cumbersolne and mefficient for the protection of these privacy interests. ${ }^{390}$ Consequently, it is preferable to protect this interest through a private, civil cause of action. Individuals whose privacy, as statutorily defined, liad been violated would be able to sue for all their

384. Miller v. California, 413 U.S. 15, 23-24 (1973).

385. For a criticism of the Court's decisions in the obscenity area, see Ingber, supra note 233, at 22-24. I am unconifortable using those decisions as a niodel for resolving the legal problems in identifying the realm of privacy. Nonetheless, attenipting to limit privacy nivasions by statutorily defining an area outside the ambit of the first amendnient nuay be far less objectionable than attempting the same task in the obscenity context. The impact of obscenity deregulation falls on the coinmunity-at-large while the effect of a privacy invasion is borne by individual victims. If the cost of the societal value in expression is to be absorbed by the societal benefactors, deregulation of obscenity is justified; deregulation of privacy invasions, however, is not. Furthernore, because privacy nuvasion suits are initiated by private claimants rather than official censors as in obscenity, and because such suits result in daniage awards rather than incarceration, the constitutional dangers are mitigated. Finally, to the extent that obscenity statutes directly focus on a coninercial enterprise, they specifcally intend to impact on the public domain, and therefore should be required to satisfy unore stringent first amendment justifications.

386. The inpact of discretion on legal decisionniaking can be affected by determining the "level of generality" at which such discretionary decisions are niade. As the decisional level noves from the generic act to the specific act and on to the specific actor, more and nore unique facts of the specific context involved niay influence decisional outconıes. At the higher level of generality, these situational factors are unknown and, thus, decisions inust focus on abstract categories of behavior which are less likely to evoke bias or passion in the decisionnaker. For a fuller discussion of the concept of "level of generality," sec Ingber, Interface, supra note 183, at 334-38; Ingber, supra note 72, at 927-30.

387. The process for deflning privacy thus would nore closely resenıble that suggested by Rawis for entitleınent deterninations. See supra note 45 . At the tine judgments were being made, everyone would be ignorant about whether he, in the future, would wish to be protected from a specific type of disclosure or would desire to disclose facts of such a nature about others.

388. See T. EMERSON, supra note 232, at 557.

389. This last factor suggests the right of an individual to "outgrow" indiscretions long since past. At some point, past events, long forgotten, should no longer be subject to public resurrection.

390. See supra text accompanying notes 71-74. Most violations likely would need to be ignored by public officials concerned with nore serious consequences of private conduct. 
specific pecuniary losses. To promote secondary cost avoidance, such losses, likely both rare and limited, clearly ought to be internalized by the media.

Further damages are necessary, however, to deter privacy invasions and achieve primary cost avoidance goals. Larger awards are needed to encourage private individuals to act as private attorneys general enforcing decency standards on the media. ${ }^{391}$ However, given that determinations of which facts fall outside of legitimate public interests always will constitute the imposition of an ideological perspective in a inanner which mevitably compromises first amendment orthodoxy, awards of general damages reinam too uncertain, uncontrolled, and subject to abuse to be authorized. Instead, a system of fixed tort fines should be created. The payment of fines to the plaintiff would both encourage plaintiffs to litigate and deter defendants from publicly disclosing those facts which the commumity has avowed are private. ${ }^{392}$ The danger remains, however, that the profit anticipated from disseminating private material unay exceed the tort fines. In such circumstances the press would retain an economic motivation to publish. To assure effective deterrence, the defendant should be required to disgorge revenues gained by the improper publication or pay the fixed tort fines, whichever is higher. ${ }^{393}$

Once developed, the proposed privacy statute could be applied in one of two ways. First, if the goal were to acheive the highest level of certainty, the statute could be administered inflexibly. Regardless of the situation, publication of matters included on the statutory list always would constitute a privacy invasion; publication of material not on the list never would be tortious. ${ }^{394}$ This proposed remedy system would greatly reduce the uncertainty which often leads to undesirable press selfcensorship. It would give notice of the kinds of publication leading to hability and place a reasonable linit on damages. Simultaneous to this recognition of media concerns, the system would assure a plaintiff vindication when his privacy has been violated. Furthermore, when possible, it would shift the economic consequences of those violations to the bene-

391. Deliberately inflated damage awards also are used in antitrust litigation, for example, to encourage private litigants to assume this enforcement role. See 15 U.S.C. $\S 15$ (1982) (awarding treble damages to successful plaintiffs).

392. Primary cost avoidance goals, thus, are fulfilled by a mixed system of general and specific deterrence mechanisms. See supra note 107.

393. These fines will be set statutorily thus limiting the risk they will be excessive. Legislators, functioning at a ligh level of generality, are less likely to harslily punisls the media than is a judge or jury infiuenced by the drama of a specific case. See supra note 386 and text accompanying notes 386 . 88.

394. Situational interests and public concern would no more justify publishing facts on the list than it would justify the press breaking into a public official's loome in order to find proof that he liad accepted bribes. Altlough the information sought in the lyypotlietical is of significant public interest, the media agents still would be subject to criminal prosecution for breaking and entering or burglary. 
ficiaries of the press' activities. Any claim by media defendants that the aggravated damages awarded are unfair could be discounted, simce the system would give the media clear notice of the financial risk it takes by publishing.

Strict application of the proposed statute, however, could conflict with first amendment interests. Contextual factors ignored under this first method may make facts, normally a matter only of private importance, significant to issues of public interest. For instance, certain public figures or holders of public office, although not stripped of all privacy rights, ${ }^{395}$ could be assumed to have exposed at least part of what normally would be private aspects of their lives to public scrutiny. ${ }^{396}$ Context might be all important.

The proposed statute may thus be interpreted either to forbid disclosure of some types of facts regardless of setting ${ }^{397}$ or retain a measure of flexibility by recognizing a newsworthy/public importance exception which would allow the degree of disclosure to depend upon the context. ${ }^{398}$ Under this flexible approach, disclosures falling within the statutory categories would be ouly presumptively private. There may be unique situations where it is proper to publically disclose even these matters. Under such a remedy scheine the press would still be better protected than it is presently. The media would never be hable for disclosures not encompassed by the statutory risk categories. ${ }^{399}$ Such disclosures would always retain their public nature. However, publishers contemplating disclosure within specifically defined risk categories and uncertain of the exception's scope still may be chilled from reporting potentially newsworthy items. ${ }^{400}$

To avoid this undesirable self-censorship, a legal mechamism should be provided that would allow a publisher to obtain prior to publication a

395. Prosser questioned whether there is any information about the President of the United States or any candidate for that office that is not a matter of legitiniate public concern. W. PROSSER, supra note 1, $\S 118$, at $829-30$ \& n.33 (discussing "the disclosure, in the election of 1884 , of Grover Cleveland's parentage of an illegitimate child many years before.")

396. A candidate for public office running on a right-to-life platform, for example, inight not realistically be able to claim as private the fact that she secretly has had an abortion.

397. The "inflexible rule" option would sacrifice the occasional loss of significant information in return for an increase in clarity and certainty and a decrease in the potential of judge or jury abuse.

398. Disclosure of an individual's past crininality, for example, might be improper when the individual plays no significant role in the community, e.g., Briscoe v. Reader's Digest Ass'n, 4 Cal. 3d 529, 538, 483 P.2d 34, 40, 93 Cal. Rptr. 866, 872 (1971), but proper when he is running for public office, e.g., Monitor Patriot Co. v. Roy, 401 U.S. 265 (1971).

399. The present system of compensation for privacy invasion lacks any meaningful definition of the scope of liability. Consequently, it does not supply the press with even this limited assurance of safety. See supra text acconipanying notes 380-82.

400. The presumptively private nature of these disclosures under this statutory system actually might lead to even greater incentive for a risk-averse publisher to self-censor than exists under the present tort system. 
quick ${ }^{401}$ and definitive determination of the newsworthiness of his contemplated disclosure. ${ }^{402}$ The proposed procedure should be adversarial. $^{403}$ Only through presentation of the opposing perspectives of the media and the mdividual about whom the disclosure is to be made may the clash of values mvolved in a privacy invasion suit be adequately considered. ${ }^{404}$ If the factfinder determines the desired disclosure is exempt from the privacy statute's coverage, the press may proceed to publish immune from suit for mvasion of privacy. ${ }^{405}$ If no exemption is found or if the publisher, for whatever reason, refrains from initiating this legal

401. The timeliness of a report often determines its public import. A legal mechanism for evaluating a disclosure's newsworthiness that fails to provide for this critical need is unlikely to satisfy first amendment requirements.

402. Similarly, the Supreme Court requires prompt judicial determination of public value as a condition for removal of allegedly obscene films from public exhibition. See Freedman v. Maryland, 380 U.S. 51 (1965).

403. The litigation costs of such an adversarial proceeding are, of course, a significant concern of any remedy system intended to minimize press self-censorship. Hopefully the limited nature of the proceeding would mimimize such costs. The truth or falsity of the disclosure would not be at issue. Presentations at the proposed hearing would be limited to a statement of the intended disclosure. Debate would be limited to its relevance to an issue of alleged public importance. Thus, little, if any, testimony should be required.

For the proposed proceeding to be successful, a modification is required of the Supreme Court's holding in Cox Broadcasting (that information in publicly availablc court records is not private). See supra text accompanying notes 374-76. A finding that the contemplated disclosure constitutes an invasion of privacy is of little worth if the process leading to the finding is itself subject to full media coverage. Other proceedings, such as state bar disciplinary hearings, are now confidential. For examples of confidentiality rules, see In re Florida Bar, 135 So. 2d 715, 734-35 (Fla. 1961) (amending article XI of the Florida Bar's Integration Rule so as to keep disciplinary hearings confidential) and In re Supreme Court Special Comm. for Lawyer Disciplinary Procedures, 373 So. 2d 1, 31-33 (Fla. 1979) (further amending confidentiality Rule 11.12). Thus it should be plausible to exclude the media from this privacy determination.

404. In addition, a jury rather than a judge preferably should make the determination of "public importance." Those situations in which presumptively private issues take on public importance often will involve public officials. Jurors may be less prone to repeatedly identify with this mediaaffected class than may judges who tend to be drawn from and associate within the same cultural milieu as do these officials. See J. ELY, Democracy AND Distrust 57 (1980). The jury, thus, is likely to better represent the public interest concerns of the community than is a judge.

Furthermore the normal dangers of jury deliberations are minimized by a remedy system which delineates, at high levels of generality, the types of disclosures which may lead to liability and which also stringently controls the extent of damages to be awarded. Instead of the present system's dependence on ad hoc determinations of privacy invasions, the jury's role in the proposed procedure is merely to designate when presumptively private information is of public interest because of some unique context. This limited jury function poses considerably less threat to first amendment values.

Finally, a legal procceding designed to determine whether the disclosure has some unusual public interest by its very nature must emphasize the situational. The variable nature of juries which often thwarts attempts to gain consistent judgments, therefore, is far less problematic when the proceedings focus is precisely the unique aspects of context.

405. If these determinations are not final but subject to appeal, a further refinement may be needed. The need for timely disclosure of inaterial already found to be newsworthy by a jury counsels against delaying publication pending appeal. Immediate publication should be encouraged. If the jury determination is reversed on appeal, however, the media should be liable only for the rare pecuniary losses which may have resulted from the disclosure. Since the press acted in good faith to determine the propriety of its disclosure, secondary cost avoidance is the predominant justification 
process, disclosure may still take place. In such cases, the publisher would be liable for the pecuniary losses the disclosure generated as well as the fixed tort fines or gained revenues. ${ }^{406}$ In such circumstances, where the ramifications of publication are clear, the decision to disclose may be viewed as a moral choice for which the press should be held accountable. Requiring the media-the better cost spreader-to internalize these costs serves secondary cost avoidance goals. This internalization also serves the primary cost avoidance function of assuring that the beneficiaries of press activities bear the costs of the privacy injuries these activities cause. ${ }^{407}$

This proposal for remedying privacy invasions would protect and vindicate privacy interests ${ }^{408}$ while simultaneously minimizing the likeli-

for liability. Any greater damages would deter or punish the media iuappropriately. Of course, if the report is inaccurate, publication may still result in a defamation suit.

406. Some consideration ought to be given to whether a publisher who discloses presumptively private material without a finding of any exemption should be entitled to a postdisclosure hearing on the newsworthiness of his publication.

407. The addition of tort fines or lost profits would provide a measure of vindication or restitutive justice for the plaintiff as well as a financial incentive to discourage the press from causing future injury. However a publisher who firmly betieves in the disclosure's importance still may be willing to publish and pay the price.

408. As is true of any system attemptiug to rectify intangible injuries through money awards, the proposed system will fall short of fully protecting privacy. Damages alone ean never correct the injury suffered by an individual whose private being has been exposed unjustifiably to the humiliation of the public limelight. An injunction prohibiting publication is the ouly legal remedy capable of truly protecting privacy interests. Given the formal process suggested by the proposed remedy scheme for determining whether the media's desired disclosure falls withm the public domain, consideration should be given to whether equitable remedies should ever be used to enforce a judgment that publication would constitute a privacy invasion.

Serious practical difficulties suggest that the use of injunctions under the proposed scheme may be undesirable. A publisher, aware that imitiating the procedure inay lead to an injunction rather than an award for damages, may prefer to avoid the process. Such behavior would eliminate the system's value both to the media and their potential victims. A means, of course, could be developed to allow individuals who fear impending privacy invasions to initiate the procedure. Except in the rare cases of repeated publication, however, an individual whose privacy is threatened is likely to be unaware of his danger until after the injurious disclosure is published.

Assuming these practical difficulties could be surmounted, the use of injunctions smacks of a constitutionally suspect prior restraint ou commumication. Prior restraints, however, arguably are only improper when they inhibit expression within the public domain. The injunctions at issue here prohibit only disclosures found irrelevant to public concerns. The problem with such analysis is that these findings are exclusively ideological and thus themselves questionable under orthodox first amendment doctrine. Still, although such determinations must not be presuned infallible, the constitutional basis of the privacy interest may rebut any presunption that favors errors of too much communication over errors of too little.

Furthermore, the restraint considered here differs markediy from the prototypical prior restraint in which the court uses the nondesirable nature of a past publication as the basis for prohibiting the publisher from making further communications in the future. E.g., Kunz v. New York, 340 U.S. 290 (1951); Near v. Minnesota, 283 U.S. 697, 713 (1931). In the procedure suggested, only the disclosure specifically found to violate privacy rights would be prolibited. But see New York Times Co. v. United States, 403 U.S. 713 (1971). It is unlikely that such limited use of equitable remedies would interfere more dangerously with free expression than does the present use of postpublication damages for privacy invasions. Risk-averse publishers may prefer the certainty of total prohibition 
hood of chilling the media from publishing information which ought to be available for public consideration. Part II of this Article has attempted to structure remedy schemes for the intangible injuries of defamation and privacy that give symbolic support and practical protection to interests which initially seem irrevocably incompatible. Such an accommodation is required if the tort system is to vindicate rather than jeopardize values fundamental to a free and decent society.

\section{CONCLUSION}

The present tort process' method for dealing with intangible injuries is misguided. It focuses too much on rules limiting liability and too little on the fundamental issues of damages and remedies generally. In some circumstances, for reasons often both arbitrary and unduly legalistic, damages are denied altogether. Some societal interests remain, therefore, unrecognized and unsupported. In other circumstances, damages are left uncontrolled. In such cases, plaintiffs receive windfalls and defendants' activities are excessively deterred through unwarranted internalization. The tort process thus has become unjustifiably burdensome.

A general review of tort law is clearly in order. A focus on the relationship between the goals of any compensation system and the remedies the system utilizes suggests the need for reform. This Article's analysis of intangible mjuries, perhaps the single most difficult problem confronted by any compensation system, as well as the reforms it proposes to deal with such injuries, constitute a beginning of this vitally needed rethinking and, perhaps, of the necessary reformation of the present system.

of a limited number of disclosures to the continued uncertainty of whether publication in a much wider and more amorphous group of situations might lead to significant liability for damages. A fiscally sensitive publisher might well feel less hampered and disclose more under a system of equitable remedies. As Professor Schauer has commented, the objections to prior restraints in many cases "are really objections to the underlying substantive rule [determining whether a specific communication is constitutionally protected], but that has nothing to do with the timing or method of restraint." F. SCHAUER, supra note 239 , at 152 . Thus, if the practical problems with equitable remedies can be eliminated, injunctions to prevent privacy invasions may well be proper. 